Master Thesis

Software Engineering

Thesis no: MSE-2007:23

October 2007

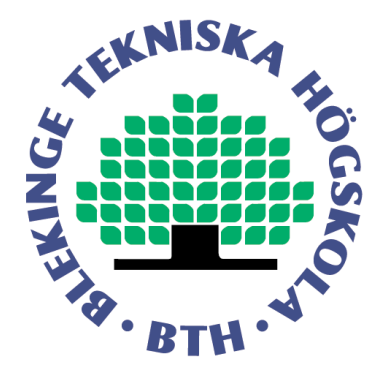

\title{
Challenges and Solutions in Test Staff Relocations within a Software Consultancy Company
}

\author{
Daniel Larsson
}


This thesis is submitted to the School of Engineering at Blekinge Institute of Technology in partial fulfillment of the requirements for the degree of Master of Science in Software Engineering. The thesis is equivalent to 20 weeks of full time studies.

\section{Contact Information:}

Author(s):

Daniel Larsson

E-mail:

d.larsson1@gmail.com

External advisor(s): $\quad$ Andreas Pettersson, Håkan Bertilsson

Company/Organisation: Cybercom South $\mathrm{AB}$

Address:

Phone:

Emdalavägen 16, 22369 Lund

+46406919600

University advisor(s):

Dr. Robert Feldt

Department:

School of Engineering (APS)

School of Engineering Blekinge Institute of Technology

Box 520

SE - 37225 Ronneby

Sweden
Internet : www.bth.se/tek

Phone : +46457385000

Fax : +4645727125 


\begin{abstract}
Test staff working in modern software consultancy companies often have to work in multiple customer projects that differ not only technically, but also regarding organisational, management and social aspects. The ease and speed with which the staff can adapt to new projects and environments is crucial for the success and profitability of the consultancy company. This paper presents the results of a study on how management in a Swedish software company can facilitate test staff relocation. Interviews with consultants in the testing department were conducted to elicit the differences between testing projects they have and are involved in and their views on the challenges of and learning needed when relocating between projects. Based on this we present an approach to better support such staff relocations in the future. The approach is based on a knowledge sharing structure and process and the introduction of specific templates to capture and document testing experience. An initial, static validation in the test consultancy show that the approach has merit and should be further evaluated.
\end{abstract}

Keywords: Project staff relocation, test consultancy, test experience template 


\section{ACKNOWLEDGEMENTS}

I would like to thank Dr. Robert Feldt most sincerely for the many constructive ideas given during this work. I am also grateful to Cybercom, more specifically to my advisor and to TestCenter management for believing in this work and for providing the best imaginable work environment.

Finally my special gratitude is given to my beloved parents for their inexhaustible moral support, which has contributed more than they think. 


\section{CONTENTS}

\section{$\underline{\text { PART } 1}$}

PAPER

P-1

PART 2

APPENDIX A - METHODOLOGY 1

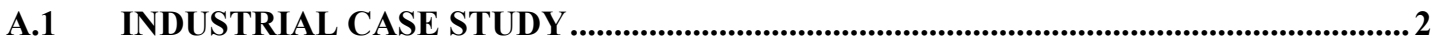

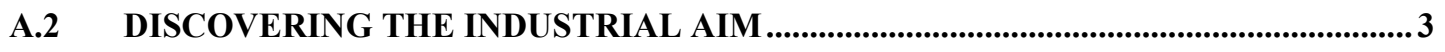

A.2.1 COMMUNICATION PRIOR TO THESIS PROJECT START ….................................................. 3

A.2.1.1 Summary of communication prior to thesis project start .......................................... 3

A.2.2 ProJECT MANAGER MEETING.......................................................................... 3

A.3 TEST CONSULTANT EXPERIENCE EXTRACTION .................................................5

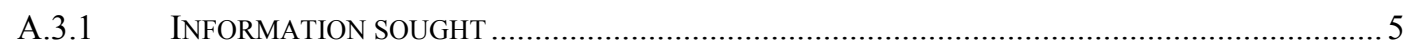

A.3.2 CHOICE OF EXPERIENCE EXTRACTION METHOD ..................................................... 5

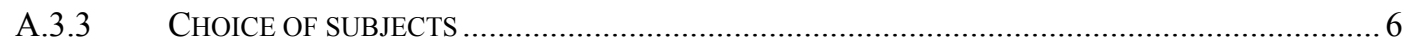

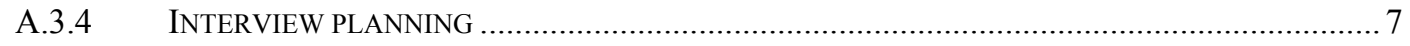

A.3.4.1 Creation of interview questions .................................................................. 7

A.4 CONSULTANT LEARNING STYLES AND PERSONALITIES .....................................8

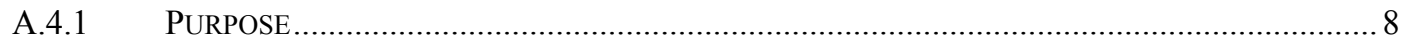

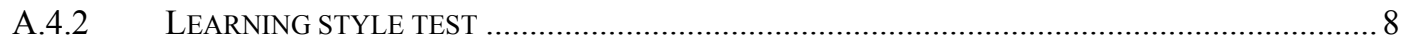

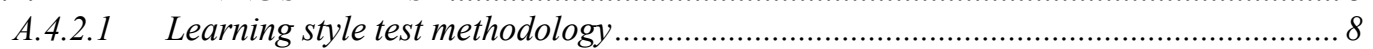

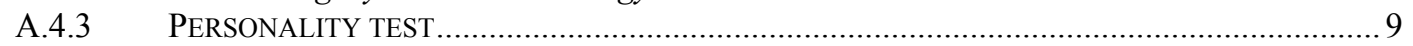

A.4.3.1 Personality test methodology ........................................................................ 9

A.5 IMPROVEMENT SUGGESTIONS CREATION ............................................................ 10

A.5.1 THE IMPACT OF PROJECT STAFF RELOCATIONS ON OTHER PARTIES THAN CONSULTANTS. 10

A.5.2 CANDIDATE APPROACHES TO IMPROVING CONSULTANT PROJECT RELOCATIONS .............. 10

A.5.2.1 Improved requirements representations ........................................................... 10

A.5.2.2 Longer introduction periods before relocation ...................................................... 11

A.5.2.3 Simultaneous introduction periods ....................................................................... 11

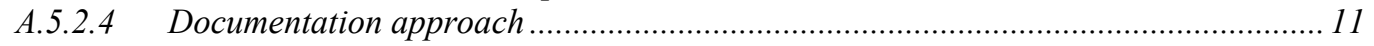

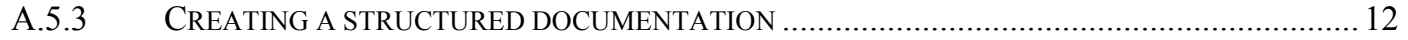

A.5.3.1 Reference literature choice .......................................................................................... 13

A.5.3.2 Knowledge reuse with experience patterns ............................................................. 13

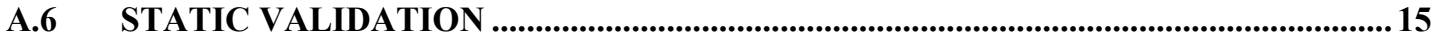

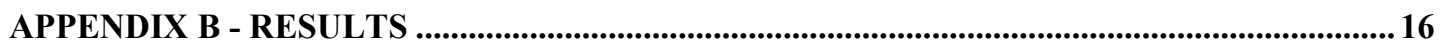

B.1 RESULTS FROM PROJECT MANAGER MEETING ..................................................... 17

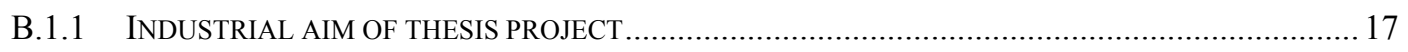

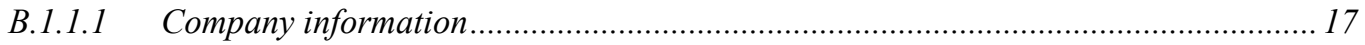

B.1.1.2 Expansion and predicted future needs...................................................... 17

B.1.1.3 The TestCenter model .................................................................................. 17 
B.1.1.4 Consultant project relocation ability............................................................. 17

B.1.1.5 Aiming to improve project staff mobility .......................................................... 18

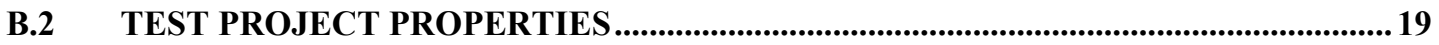

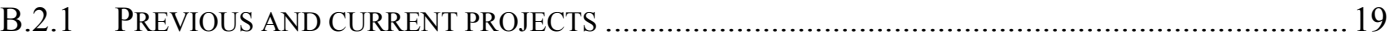

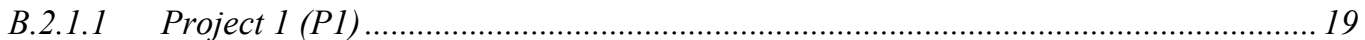

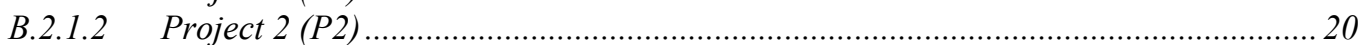

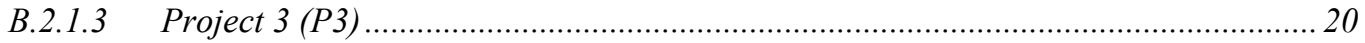

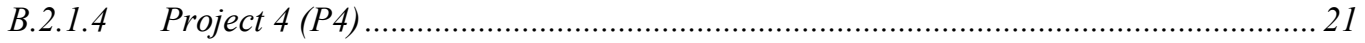

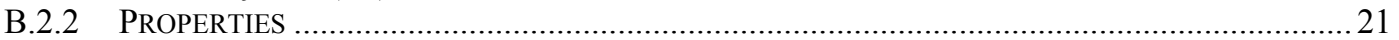

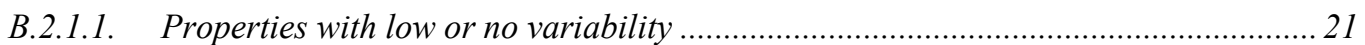

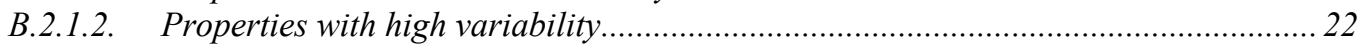

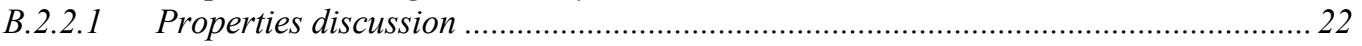

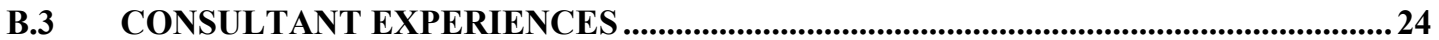

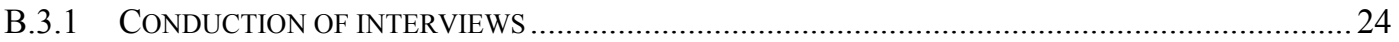

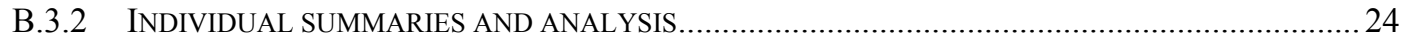

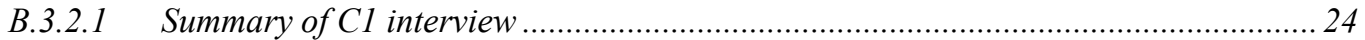

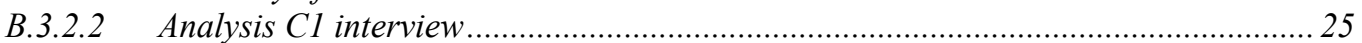

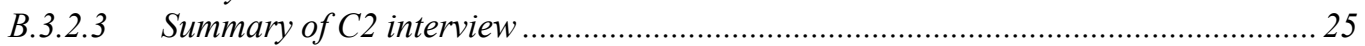

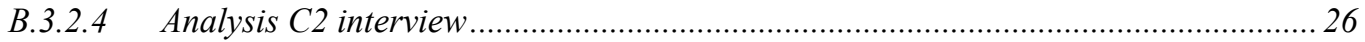

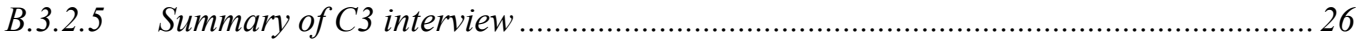

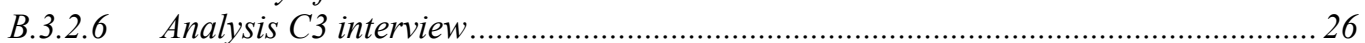

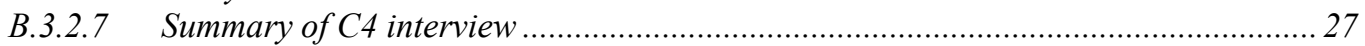

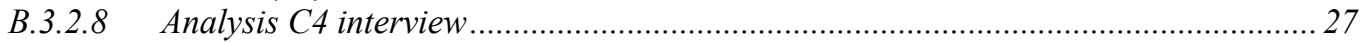

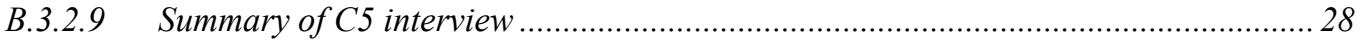

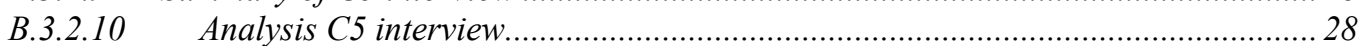

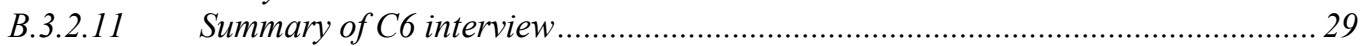

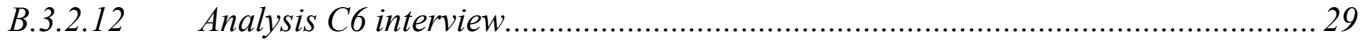

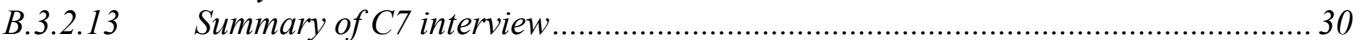

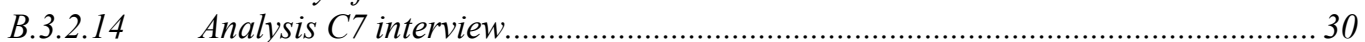

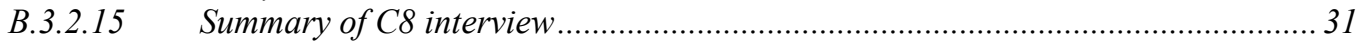

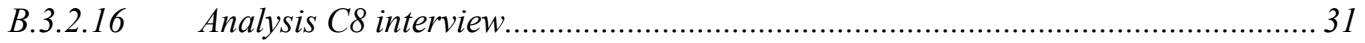

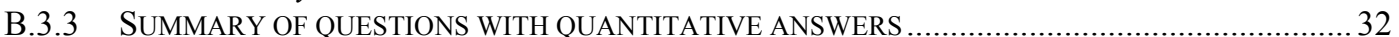

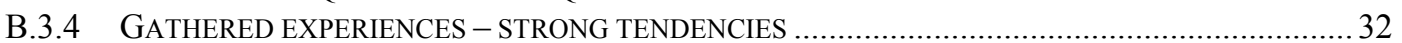

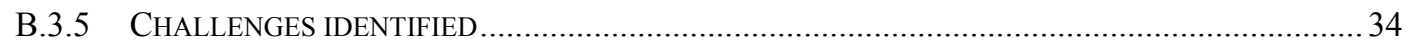

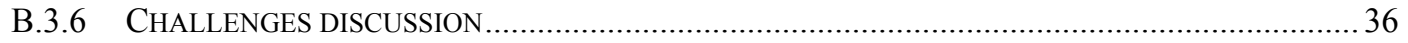

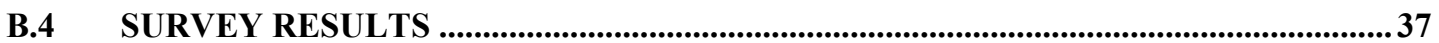

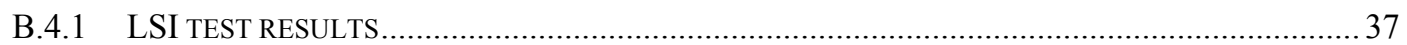

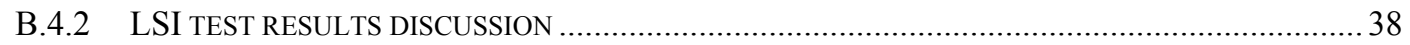

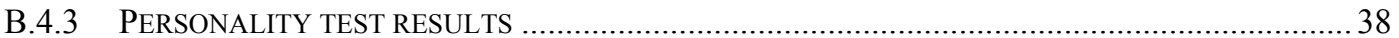

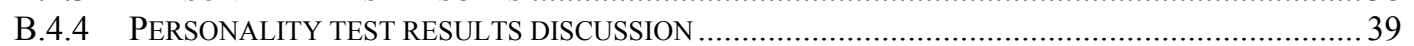

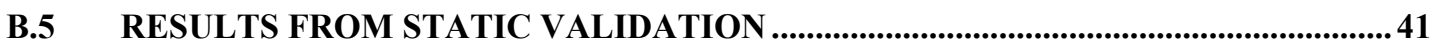

B.5.1 DISCUSSION OF RESULTS FROM STATIC VALIDATION .......................................................... 41

APPENDIX C - INTERVIEW QUESTIONS AND ANSWERS ................................................43

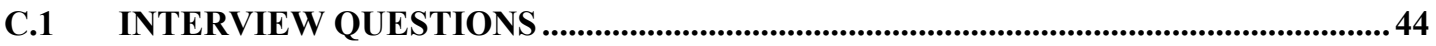

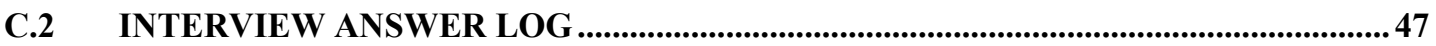

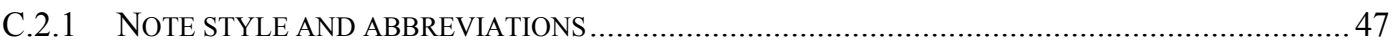

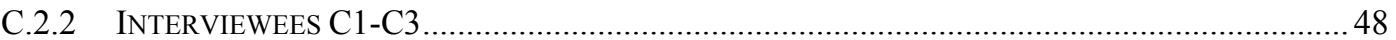

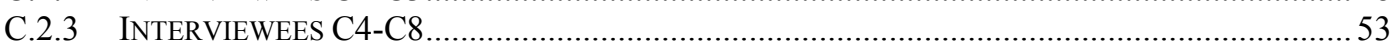




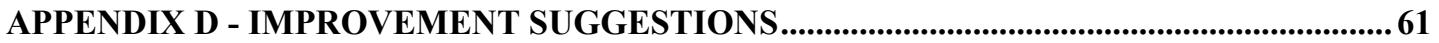

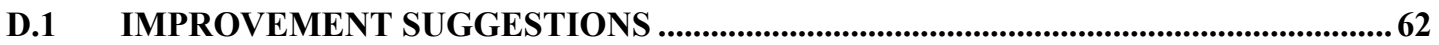

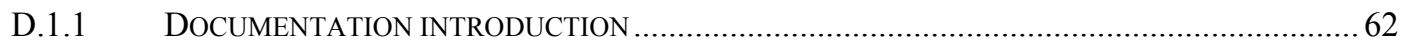

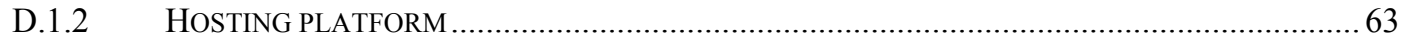

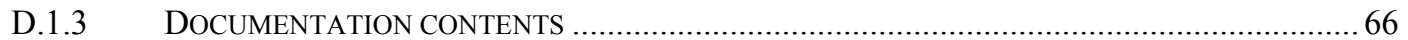

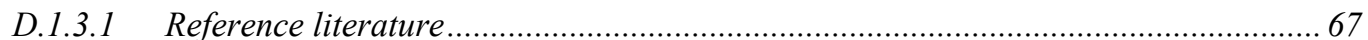

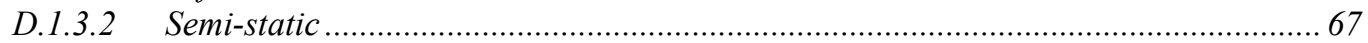

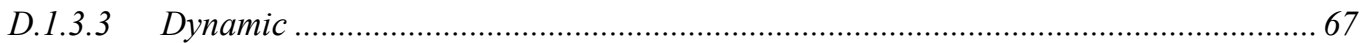

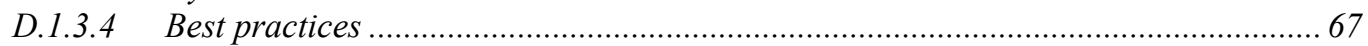

D.1.4 PROCESS OF INTRODUCING AND MAINTAINING HOTDOG DOCUMENTATION ..................... 68

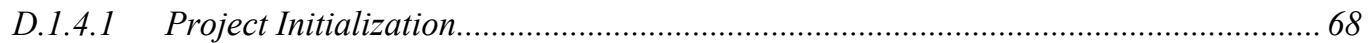

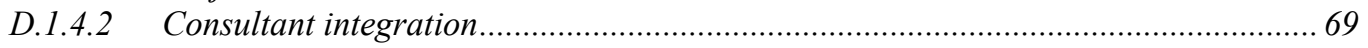

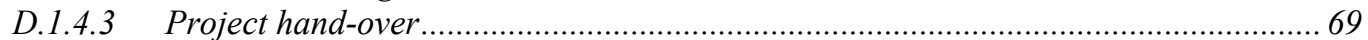

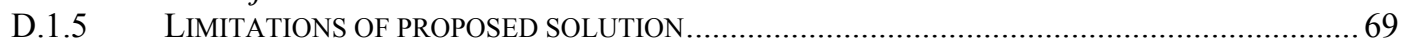

D.1.6 SECURITY CONSIDERATIONS OF KNOWLEDGE ENCODING ........................................... 70

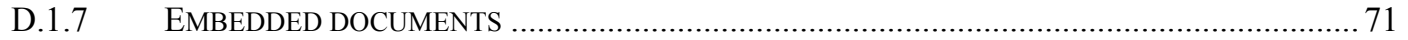

APPENDIX E - QUESTIONS AND ANSWERS FOR STATIC VALIDATION .........................75

E.1. QUESTIONS AND ANSWERS FROM STATIC VALIDATION INTERVIEW ........... 76

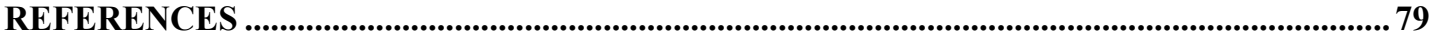




\section{THESIS OUTLINE}

During 2007 a new Master Thesis format was suggested by staff at the APS department at Blekinge Institute of Technology. The introduction of this new format - the Hybrid Master Thesis (HMT) - was based on several reasons. One was that traditional Master Thesis reports can become very large and difficult to overview. Another was that the institute strived to promote the possibility to publish material from student thesis projects. Therefore the HMT format was outlined to contain two main parts; Part 1 is a paper written in IEEE/ACM format and covers the crucial thesis project contents and is also adapted towards publication. Part 2 is a series of appendixes which present and separate detailed methodology from specific results and other parts.

This Master Thesis project is presented as a prototype version of the HMT format, and thus follows the previously described structure. The paper has been written in IEEE format since it was targeted for submission to the ICST 2008 conference ( http://www.cs.colostate.edu/icst2008/index.html). The function of this paper has been to summarize and connect the different parts of the thesis project work. It also contains an additional discussion about validity threats. The paper is followed by five appendixes and an overall reference list. Appendix A describes in detail the methodology of the study. Appendix B presents specific results and discussions from all activities, thus is corresponds to activities described in Appendix A. The three remaining appendixes contain even more details, in which Appendix $\mathrm{C}$ contains interview questions and answers, Appendix $\mathrm{D}$ presents the improvement suggestions made and Appendix E finally covers details from the static validation of improvement suggestions. 


\title{
Challenges and Solutions in Test Staff Relocations within a Software Consultancy Company
}

\author{
Daniel Larsson \\ School of Engineering \\ Blekinge Institute of Technology, PO Box 520, S-372 25 Ronneby SWEDEN \\ d.larsson1@gmail.com
}

\begin{abstract}
Test staff working in modern software consultancy companies often have to work in multiple customer projects that differ not only technically, but also regarding organisational, management and social aspects. The ease and speed with which the staff can adapt to new projects and environments is crucial for the success and profitability of the consultancy company. This paper presents the results of a study on how management in a Swedish software company can facilitate test staff relocation. Interviews with consultants in the testing department were conducted to elicit the differences between testing projects they have and are involved in and their views on the challenges of and learning needed when relocating between projects. Based on this we present an approach to better support such staff relocations in the future. The approach is based on a knowledge sharing structure and process and the introduction of specific templates to capture and document testing experience. An initial, static validation in the test consultancy show that the approach has merit and should be further evaluated.
\end{abstract}

\section{Introduction}

An attribute of software development projects is that they tend to have a more dynamical content than projects in other lines of business [1]. Compared to the construction of a house, the construction of a software system can often pose additional challenges to project members. One reason is the continuous changes of both construction tools and goals throughout the project's life-time[1]. Together with more general challenges of typical project work, like multicultural aspects and project members participating in several simultaneous projects, these challenges increase the work complexity posed to software engineers today. If focusing on a smaller part of software engineering, in our case test projects, the situation becomes even more interesting. Overall diversity of test work was described in [2], in that the overall goal varies from pure reporting of errors, to error tracking and correction and even demonstration of proof of correctness. The latter was proposed as unfeasible already in 1979 by Dijkstra [3], but such efforts appear still today for i.e. certification purposes. The degree of development involvement also varies for test engineers, depending on development model used [4]. Test projects are in addition smaller than the development projects they are associated with, and thus imply that test staff needs to relocate between projects more frequently. These project staff relocations can become even more challenging to test engineers in a consultancy context, especially if management actively strives to maintain balanced consultant workloads. General consultancy challenges, such as creating understanding for the vision of external actors and need for mutual knowledge exchange, also need to be handled by test consultants. The nature of such diverse project work naturally raises questions about what degree of adaptability it requires from test consultants and how they respond to that requirement. This study focuses on the challenges this test consultancy environment poses in project learning aspects for consultants.

In the next section the aim with this study is presented. Section 3 summarizes the method used while section 4 contains specific results and a related discussion. In section 5, static validity is discussed along with validity threats and a revisit to initial research questions is made. Conclusions are then presented in section 6 and finally section 7 presents identification of future work.

\section{Aim of the study}

We present in this section industrial interest from a software consultancy company to explore the area, together with research questions that we focused on. 


\subsection{Industrial background and aim}

The company that participated in this study was Cybercom Group AB, an IT consultancy company group with software development as one cornerstone. The company was founded in 1995 with Sweden as base of operations, and is today internationally represented in six countries and over 1200 employees. The study was conducted at TestCenter, a department that is dedicated to software testing for the regional company Cybercom South. Traditionally TestCenter has been involved in two main types of test projects. One implies full test responsibility within in-house product development of Cybercom. Another involves a subset of test responsibilities in development projects owned and managed by customers. The second type can be further divided into test consultant resource reinforcements at customer site or testing efforts conducted at TestCenter premises. The latter is typical for projects with large test commitments.

The request by TestCenter for academic support was founded in a concern for how to offer support to their consultants so that they could learn and adapt to new projects and environments faster. This was primarily related to a managerial aim for TestCenter to improve their ability to conduct a large number of test projects in parallel in the future. It was believed that having shorter project learning periods for consultants in each project would have positive results on total efficiency. TestCenter had also learned that test work often appears as bursts, and in their case often close to iterative releases. This resulted in the introduction of a resource planning model called TestCenter Model. Its main purpose was to stabilize and maintain high consultant workloads by moving consultants between projects more frequently even during project lifetimes. The aim for their participation in the study was to receive guidelines for how to help consultants learn new projects faster and thereby maximize consultant compliance with the demands for frequent project staff relocations in the future.

\subsection{Related work}

Human resource management (HRM) has become an important discipline during the last decades [5]. Much research has been done out of a management strategical perspective $[5,6,7]$. Most of this work relate to HRM in traditional company structures, i.e. it is not specific to consultancy companies. It was recognized in [8] that knowledge about HRM in modern project-intensive companies is too small and needs to be extended. In [9] four key challenges with
HRM in such companies were identified; competency, trust, change and people. The study concludes that important questions about how to improve individual work performance (the people factor) in a projectintensive context remain. Studies that consider the people factor in companies where projects are not a large constituent element of business often identify general issues. Examples are individual ability for teamwork, work preferences and concern for workfamily balance [10]. In project-intensive companies additional aspects might be relevant, such as what factors form the individual ability to adapt to new and dynamic project environments. A gap in management research for such matters can thus be identified and needs to be filled.

One common way of helping project members adapt more easily to new projects is by using mentorship for the purpose of information and goal distribution. Bjørnson and Dingsøyr present a study on mentorship in a small software consultancy company, and conclude that it creates faster learning and positive work attitudes in that setting [11]. However, they also describe that typical mentorship spans from six months and up to several years, which could make it less feasible for use in projects with shorter lifetime in general (such as software testing projects).

Weiser and Morrison suggest in [12] that a likely obstacle that prevents team members from effectively adapting to new projects is that project information is not available in a form that explains the whole project context, such as project history and purpose. A promising approach called "Project Memory" [12] is presented, which is believed to help new team members learn projects faster by dividing and collecting information into different classes such as people, meeting outcomes and decision rationales. The approach requires extensive and detailed documentation efforts, which might not be feasible in a consultancy context where project insight often is limited.

As can be seen, the relatively small set of related work that exists often focuses on wide general management practices. The lack of research from a Software Engineering perspective is even more troubling, since the SE industry enforces some of the most dynamic and project-intensive work environments of all.

\subsection{Research questions and expected outcomes}


Since no research could be found that correctly describes the central concept in this study, the following definition has been used;

The term Project staff relocation (or short form relocation) describes the process of a project member being moved from the participation in one project into another project, including initial learning processes to an extent that enables the consultant to work reasonably independently. If a project member has been relocated, he or she has no further obligations to the project relocated from.

The research questions that arose were;

1. What are the properties of test projects in TestCenter today?

2. What challenges do these properties present to the general work situation of test consultants at TestCenter?

3. What challenges are associated with relocations between different test projects in consultancy companies?

4. What improvement efforts can be suggested in order to help test consultants relocate faster into newly assigned test projects?

The generality of these questions was intentionally large, and the purpose with the study was not to produce undisputable and complete answers.

A number of expected outcomes were specified that would lead the study towards its aims. A summary of project properties that likely contribute to the complexity of consultancy test work should be extracted from real projects. A presentation of what challenges await test consultants when they are relocated between test projects was set to be the most central outcome. Furthermore suggestions for improvements, in form of guidelines or a method that could be applied to the software consultancy firm that participated in this study were a required outcome. Finally the results of a performed validation should be presented together with a discussion of the suitability of the suggested improvements.

\section{Method}

In order to produce the desirable outcomes we have performed an explorative, qualitative case study. Since there were only a limited number of test consultants that would be available for use in the study, a quantitative approach was not likely to give statistically significant results. Initial meetings with Cybercom were held prior to project start with the purpose of defining the goals of the study. When the purpose was clear and aligned with the academic aspect of the work, a project plan was developed and executed throughout the work. Improvements suggestions were developed from the results of two main information gathering steps and one supportive. It was finally statically validated with TestCenter. The overall method used in the case study can be seen in Figure 1.

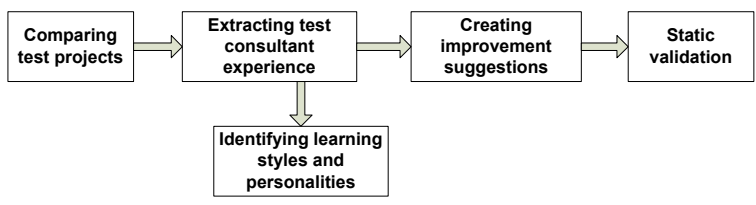

Figure 1. Method overview

\subsection{Comparing test projects}

Since experience from the different projects of TestCenter would later be extracted from test consultants, we first explored and defined these projects. One reason for this was that the result would enable a comparison between the different projects. This was in turn relevant to expose properties that seemed to form the varying nature of test consultancy project work thus answering research question one. Another motivation for this step was that the insight would likely help plan and extract relevant experiences from consultants.

The comparison of test projects was conducted as a meeting with the project manager of TestCenter and one of the test consultants. Prior to the meeting an agenda were sent to the participants to improve efficiency. The agenda contained information requests covering both test project specifics and definition of the industrial aim, as shown in Table 1.

Table 1. Project information areas

\begin{tabular}{|c|c|}
\hline Area & Examples \\
\hline Project-specifics & $\begin{array}{ll}\text { - } & \text { Customers } \\
\text { - } & \text { Time and duration } \\
\text { - } & \text { Responsibilities } \\
& \text { staff roles }\end{array}$ \\
\hline $\begin{array}{l}\text { Future concerns } \\
\text { for TestCenter }\end{array}$ & $\begin{array}{ll}\text { - } & \text { Expansion areas } \\
\text { - } & \text { Desirable project types } \\
\text { - } & \text { Staffing }\end{array}$ \\
\hline $\begin{array}{l}\text { Industrial aim } \\
\text { for the study }\end{array}$ & $\begin{array}{ll}\text { - } & \text { Relocation background } \\
\text { - } & \text { Scope } \\
\text { - } & \text { Budget for } \\
\text { implementation }\end{array}$ \\
\hline
\end{tabular}


While industrial aims had been defined earlier, there was still room to further discuss the scope and budget of desired improvements suggestions.

\subsection{Extracting test consultant experience}

The activity of extracting experience from test consultants became an important step in the study. This step was needed for two reasons. The first was to answer research questions number two and three, thus identifying challenges of project learning and relocation. The second was for the results to guide the creation of improvement suggestions that would relate to research question four. The author was kindly given access to meet and interview all nine consultants that were presently working at TestCenter. This was seen as a good opportunity and a semi-structured interview approach was believed to be the best suited methodology for this purpose. Interview questions mainly contained open-ended questions but also a few of Likert type (Appendix C, C.1). Other research methodologies were considered but would not have been appropriate. Quantitative methodologies such as surveys or questionnaires would neither provide the depth needed nor be of statistical significance due to the low number of respondents. Ethnographic study [13] was discarded because of the time limitations and the researcher's lack of prior experience from this research methodology. It would however likely be feasible for future research to build studies on both these two mentioned methodologies.

Basic experience background for consultants was given by the TestCenter project manager and created prioritization opportunities. While nine participants would not be too much to include, there was still a risk of dropouts since the interview period was limited and spanned the Swedish summer vacation period. The prioritization therefore was made in three levels; 1) Consultants which had been relocated between projects, 2) Having two consultants for each project listed, and 3) Shortest time since last project introduction. An additional aspect was that all consultants should at least be invited in order to avoid any tensions from unfairness in the team. Fortunately, all consultants but one (i.e. eight) could be interviewed. This created a mixture of interviewee background factors, such as experience, age and gender in the results. Questions were divided into a common background part, a project-specific part and a relocation specific part. A few questions were of Likert type but most were open-ended questions. Everyone answered the background part and the project-specific part for at least one project. Those that had previously relocated answered that part as well, and those that had not were, depending on time usage, asked a few more detailed questions in the project-specific part.

\subsection{Identifying learning styles and personalities}

In order to support the interview results and to expose any obvious correlations between the perception of test project learning and personal learning style preferences a learning style test followed the interview stage. The test chosen was the one associated with the Learning Style Inventory (LSI) by Kolb et al [14]. This model is explained more thoroughly in appendixes in this thesis, but is based on the theory that learning is a cycle process which can be divided into four stages. Each person has a preferred stage in this cycle. It should be noted that LSI tests have been criticized for only considering the relative differences between attributes within each individual, thus it is not suitable for comparison between several individuals in a population. As it was not the purpose of this study to do so, this was regarded the best choice of test to conduct. Interviewees took the test as an electronic survey which was hosted on the internet site SurveyGizmo [15]. SurveyGizmo was chosen because it offered the basic input types needed in the form, form creation process was fast and there was no cost associated with it.

Feldt et al. [16] investigated correlations between personalities and perception of project work in an industrial Software Engineering context, by using the IPIP 50-item test [17]. This test is based on the FiveFactor Model [18]. The test was seen as a feasible complement to the learning style test, because personality factors can have a large impact on relocation experiences. It was therefore bundled together with the LSI test. Respondents were invited after each interview to participate on a voluntary basis and all eight consultants participated in both tests.

\subsection{Creating improvement suggestions}

In order to answer the fourth research question there was a need to select a suitable area for improvements. The specific suggestions were later based on the knowledge gained from previous parts of the study.

It is clear that the term "fast relocation" could include many different aspects. For instance, psychological factors, social factors, and project content learning ability could all be included as 
different influencing factors of project adaptation ability. It is likely that all of these contribute to the total adaptation process of project members, and also that none is independent of the other. Psychological and social factors have not been considered in this study. Instead creation of improvement suggestions were focused on decreasing challenges of project content learning in project staff relocation situations.

\section{Results}

In this section results from the case study steps can be found, including project properties that are likely to cause test work diversity in test consultancy contexts, challenges associated with project staff relocations and a high-level description of the improvement suggestions.

\subsection{Project properties}

We were able to extract information about four different test projects and their properties at TestCenter. Three properties with low or no variability were found, meaning that the projects were very alike with regards to them.

Table 2. Low variability project properties Properties with low or no variability Embedded software (prop1)

Manufacturing customer (hardware devices) (prop2)

Agile context (prop3)

The first two are likely influenced by TestCenter business focus. It was also noteworthy that the agile development model dominated even though projects were conducted by three independent software development companies.

Table 3. High variability project properties Properties with high variability Different hardware platforms (prop4)

Ultimate purpose of testing (find error or correctness) (prop5)

Test activities (planning/execution etc) (prop6)

Test types (load, regression etc) (prop7)

Development involvement (prop8)

Process ownership (prop9)

Physical location (prop10)

Size of TestCenter staff (prop11)

Project documentation dynamics (prop12)

Project stability (prop13)

Test project length (prop14)
One highly varying property that seemed to have a large overall impact was the total responsibility of TestCenter (process ownership and development involvement), even though other highly variable properties were found. We also conclude that test project lengths ranged from six to eighteen months. While these properties are discussed further in results appendixes of the master thesis we conclude that there exist many dynamic properties in typical projects with test consultancy participation and that they contribute to the complexity experienced by test consultants.

\subsection{Consultant experiences}

Results from interviews showed, among others, that consultants had very uniform academic engineering education and that none had studied academic courses on specific software testing subjects. Upon project starts or relocations consultants experienced a lack of time for preparation. Prior knowledge about the software development models that were used in the projects (agile models) was minimal, indicated by uniform Likert scale responses of 1 out of 5. Overall there was a heavy dependency upon verbal communication when consultants learned to work in new projects. Learning by verbal communication involved both interactions between consultants and developers, and between consultants. Only one consultant acknowledged that the relocation had resembled a structured process with different introduction steps. Project documentation quality was considered to be moderately good with a mean value of 3 out of 5 , however documentation in different projects were structured in fundamentally different ways. This made it harder for the consultants to know where to look for written information when they were learning new projects. The fact that test cases in one project (Project P1, see Appendix B, 2.1.1) were predefined from a third party certification authority, seemed to have lead to a lower motivation level than in other projects and that there was no obvious requirement for creativity in this project. There was room for some creativity, but only in tweaking the test tool settings and in the choice of tools to be used. We conclude that the experienced challenge from project P1 was to test the test method itself rather than a piece of software. Another finding was that the members of Project P1 on their own initiative created and collectively maintained a step-by-step instruction manual with additional tips and tricks for the test 
process in one project (a.k.a. the LazyDog). The LazyDog consisted of a single document which listed a number of issues, most oftenly troublesome test cases but also test tool issues. Interviews indicated that the LazyDog was a popular documentation and that it arose out of natural needs.

The interview parts concerning the third research question, thus regarding how relocations were experienced, showed an unpredicted positive attitude. Consultants that had experienced project relocations thought that relocations were overall positive and improved motivation. It can be questioned if this part of the study exposed the whole truth. There are factors that may have prevented the exposure of negative effects of project relocations. Examples are that a larger number of experienced relocations would be necessary and that previous relocations almost always meant moving the consultant from lower-motivational Project P1 into another. This can be an indication that a future case study in TestCenter or in another test consultancy company would result in other relocation experiences.

Despite positive experiences of relocations, a number of challenges could be identified. These were often associated with learning issues in the new projects. The identified challenges are shown in Table 4.

Table 4. Project learning and relocation challenges

\begin{tabular}{|l|l|l|}
\hline Description & $\begin{array}{l}\text { Nr of } \\
\text { sourc } \\
\text { es }\end{array}$ & $\begin{array}{l}\text { Property } \\
\text { relation }\end{array}$ \\
\hline Knowing who to ask & 1 & \\
\hline $\begin{array}{l}\text { Not to disturb others more } \\
\text { than necessary }\end{array}$ & 2 & \\
\hline $\begin{array}{l}\text { Late answers because of } \\
\text { communication only } \\
\text { through dedicated contact } \\
\text { persons }\end{array}$ & 1 & \\
\hline $\begin{array}{l}\text { Test case creation based on } \\
\text { system knowledge and } \\
\text { technical competence } \\
\text { (instead of extending old } \\
\text { cases) }\end{array}$ & 2 & \\
\hline $\begin{array}{l}\text { Learning existing customer } \\
\text { product } \\
\text { (software+hardware) }\end{array}$ & 2 & Prop4 \\
\hline $\begin{array}{l}\text { Learning customer } \\
\text { terminology }\end{array}$ & 1 & Prop9 \\
\hline $\begin{array}{l}\text { Becoming socially accepted } \\
\text { at customer site }\end{array}$ & 2 & Prop10 \\
\hline Customer discouraged study & 1 & Prop10 \\
\hline
\end{tabular}

\begin{tabular}{|c|c|c|}
\hline $\begin{array}{l}\text { of documentation because } \\
\text { customer did not consider it } \\
\text { productive }\end{array}$ & & \\
\hline $\begin{array}{l}\text { Avoid stepping on } \\
\text { someone's toes }\end{array}$ & 1 & Prop10 \\
\hline $\begin{array}{l}\text { Insufficient requirements } \\
\text { specifications } \\
\text { poorly illustrated) }\end{array}$ & 5 & Prop12 \\
\hline $\begin{array}{l}\text { Limited influence in project } \\
\text { documentation } \\
\text { consulting }\end{array}$ & 1 & Prop12 \\
\hline $\begin{array}{l}\text { Lack of test plan - resource } \\
\text { planning failure }\end{array}$ & 1 & \\
\hline $\begin{array}{l}\text { Knowing where to find } \\
\text { information }\end{array}$ & 1 & \\
\hline $\begin{array}{l}\text { Distraction from learning } \\
\text { new project because } \\
\text { receiving questions about an } \\
\text { old project. }\end{array}$ & 1 & \\
\hline $\begin{array}{l}\text { Purpose of Project P1 } \\
\text { individual test cases hard to } \\
\text { understand }\end{array}$ & 1 & Prop5 \\
\hline $\begin{array}{llr}\begin{array}{l}\text { Insufficient } \\
\text { preparation }\end{array} & \text { time } & \text { for } \\
\text { relocation } & \text { prior } & \text { to }\end{array}$ & 3 & Prop13 \\
\hline $\begin{array}{l}\text { Not enough time to write } \\
\text { routines down during } \\
\text { project }\end{array}$ & 1 & \\
\hline
\end{tabular}

"Nr of sources" contains the number of consultants that have acknowledged each challenge. The column Property Relation shows which of the previously described test project properties seem to contribute to each challenge. As can be seen, challenges are not only caused by those project properties previously identified. Instead more universal project environment properties seemed to contribute to more than half of the challenges. The most recognized challenge was insufficient requirements specifications. This might be an important challenge to overcome since testing in TestCenter has traditionally been at system level, which creates large prerequisites on the understanding of system requirements [2]. A factor that seemed to contribute to insufficient requirement representations was the agile context within which all listed projects were conducted. Traditional (non-agile) development methodologies, such as the waterfall model, rely on more formal and static requirements than agile [19]. This raises a question whether test consultancy work would be better suited with development within traditional models. An imaginable obstacle to improving requirement engineering practices in the consultancy context is that project documentation in 
many cases is not owned or even accessible by Cybercom.

The second challenge, "Not to disturb others", are likely a result of the high dependence of verbal communication in previous project learning situations. Furthermore we see that relocations into customer-site projects pose challenges of social adaptation into customer environments. Experiences of insufficient preparation time can be an indication that suitable improvement suggestions should enable the start of project learning processes before relocations take place.

Results from the learning style tests and personality tests showed that TestCenter consultant personalities were quite similar to those from Software Engineers [16]. Only three of four learning styles from the Kolb model were represented in TestCenter. However, the small number of data points was not sufficient to prove a deviation in form of whether the fourth learning style (Accommodator) was truly underrepresented.

\subsection{Improvement suggestions}

Presented in this section is the high-level description of the suggestions posed to TestCenter for improving the process of project staff relocations. As previously described, these are based on relocation challenges identified.

4.3.1. Central documentation. The basic philosophy behind improvement suggestions became for TestCenter to introduce a structured relocation process. As a first step in this process a template based documentation solution called HotDog was introduced. Each project should have a HotDog of its own, and be maintained by the consultants in that project. The contents of this documentation were based on knowledge categories that related to seven out of ten of the challenges associated with test project learning and relocation. The content was translated from the Swedish template and is shown in Table 5.

Table 5. HotDog contents

\begin{tabular}{|l|l|}
\hline $\begin{array}{l}\text { HotDog input } \\
\text { label }\end{array}$ & Intended content \\
\hline Project name & The project name \\
\hline $\begin{array}{l}\text { Customer } \\
\text { information }\end{array}$ & $\begin{array}{l}\text { Customer organization, } \\
\text { intentions business area, } \\
\text { product area etc. }\end{array}$ \\
\hline $\begin{array}{l}\text { Product } \\
\text { information }\end{array}$ & $\begin{array}{l}\text { Software system info; purpose, } \\
\text { high level architecture, } \\
\text { development model, }\end{array}$ \\
\hline
\end{tabular}

\begin{tabular}{|l|l|}
\hline & programming language \\
\hline Commitment & TestCenter commitment \\
\hline Reference literature & $\begin{array}{l}\text { Relevant texts, general and } \\
\text { specific purpose. }\end{array}$ \\
\hline Contacts & $\begin{array}{l}\text { Contact info and description of } \\
\text { contact roles and competencies }\end{array}$ \\
\hline Practicals & $\begin{array}{l}\text { Practical information about } \\
\text { customer site }\end{array}$ \\
\hline Link archive & $\begin{array}{l}\text { Links that provide central } \\
\text { access point to all relevant } \\
\text { documents }\end{array}$ \\
\hline Terminology & Terminology \\
\hline Test process & $\begin{array}{l}\text { Process description and room } \\
\text { for future embedded LazyDog } \\
\text { document }\end{array}$ \\
\hline Test tools & $\begin{array}{l}\text { Tool descriptions and screen } \\
\text { dumps }\end{array}$ \\
\hline Test case examples & Embedded document or links \\
\hline Best Practices & See 4.3.2. about TET \\
\hline
\end{tabular}

The overall value of the documentation solution is not limited to obvious advantages of improving learning speed, but also by those of economical aspects. While current project learning has consisted of only verbal communication, the same information has needed to be repeated for each consultant that joins a project. With the HotDog solution, knowledge can thus be reused, which should be a leap forward to TestCenter. Additionally it has been even more costly since it is common that several persons need to be asked before the right one is found. The most crucial limitation to a documentation introduction was that it can only use a minimum of time resources from the consultants. Therefore the documentation template itself was made as short and concise as possible. The idea behind the documentation was that consultants themselves should be responsible for building and maintaining the information in it on a regular basis, even though management should insert initial information. A basic assumption of why this should work was that there already existed experience and positive attitudes from consultants maintaining a similar documentation (the LazyDog). While the LazyDog was project-specific, the HotDog approach aims to be more general and could be used in all TestCenter projects. As such it can introduce a common documentation structure that, even if the detailed contents differed much between projects, the consultants would know where to find the information.

Along with the contents of HotDog, as shown in Figure 2, introduction and updating procedures were suggested, depending on three typical relocation 
situations; Project initialization, Consultant integration and Project hand-over.

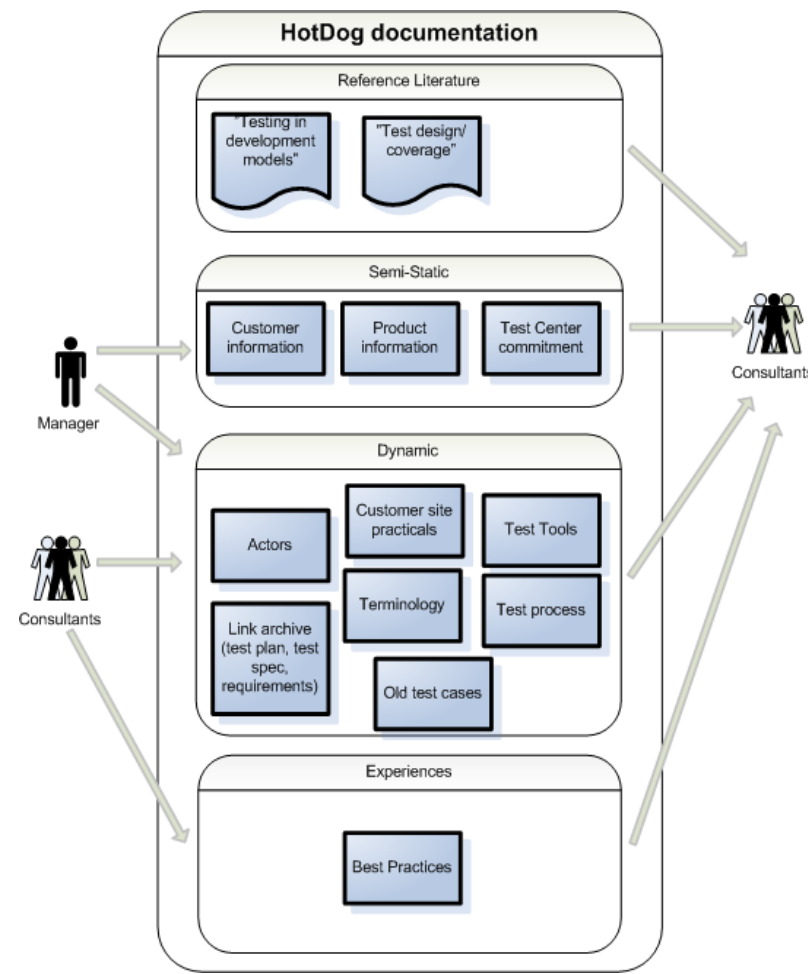

Figure 2. HotDog structural overview

It was recommended that the HotDog solution be hosted on an encrypted web page at a later stage to increase accessibility in non-local environments, but that the focus on evolving the right content categories should be the better initial focus. In addition to documentation contents suggestions were made regarding introduction and update processes for different relocation situations.

In the end this approach was believed to decrease approximately half of the 17 identified challenges and thereby to create faster project staff relocations. This was not only by creating shorter introduction periods but also by reducing the problem of removing knowledge from the project relocated from. That way distraction caused by receiving questions about the last project, could also be reduced.

Since the improvement report did not suggest exactly what information should be noted, faith was put on test consultants to find a useful level of details in order to decrease learning challenges. Among the challenges not affected by the HotDog solution is the lack of insufficient requirements, which is complex in that TestCenter does not control requirement documents and the introduction of own versions would require massive work efforts to create and maintain. The challenge of how to improve social acceptance on customer site is also not directly affected by HotDog. It is however likely that those consultants who have initial project knowledge from a HotDog from the first day at customer site could earn larger initial credibility.

4.3.2. Test Experience Templates (TET). While the first sections of the HotDog included areas that covered explicit knowledge, the second part proposed a customized version of an existing experience gathering template. The original version was created and has successfully been used by Siemens for several years in order to make use of software engineering experiences [20]. Knowledge entered into their best practice templates formed best practice patterns for usage within their global software development projects. We proposed the use of a customized version of the Siemens template for experience collection in the software testing context. We call the adapted version of Siemens best practice templates for Test Experience Templates (TET). A modified subset of the information categories included in the Siemens version was used.

Table 6. TET contents

\begin{tabular}{|c|c|}
\hline TET input label & Intended content \\
\hline ID & $\begin{array}{l}\text { Unique } \\
\text { identification } \mathrm{nr}\end{array}$ \\
\hline Type & $\begin{array}{l}\text { Process/Communication/Techno } \\
\text { logy }\end{array}$ \\
\hline Goal & Goal/target/issue \\
\hline Situation & $\begin{array}{l}\text { Scenario in which issue } \\
\text { occurred }\end{array}$ \\
\hline $\begin{array}{l}\text { Prerequisites/Limit } \\
\text {-ations }\end{array}$ & $\begin{array}{l}\text { Conditions to Test Experience } \\
\text { feasibility }\end{array}$ \\
\hline Action & Action taken to solve issue \\
\hline $\begin{array}{l}\text { Gain } \\
\text { Consequences }\end{array}$ & Effect of taken action \\
\hline Related objects & $\begin{array}{l}\text { External files that extend the } \\
\text { TET }\end{array}$ \\
\hline Noted by & Author of TE \\
\hline Comment & $\begin{array}{l}\text { Information that does not fit } \\
\text { other labels, i.e. project post- } \\
\text { mortem feedback. Supports } \\
\text { identification and future } \\
\text { insertion of missing TET } \\
\text { categories. }\end{array}$ \\
\hline
\end{tabular}

In order to create a positive perception of the Test Experience Template it was called Best Practices in the 
HotDog. This label focused on positive learning and was believed to look more appealing and thus promote its usage. Naturally all experiences can not be used to create best practices and would thus not be written in a Best Practice context. However the gathering of even the simplest of learning, in a form of best practices, should be a step towards a practically useful codification and reuse of tacit knowledge. While more frequent project staff relocations would mean that each test consultant will participate in many projects, it is believed that a massive amount of tacit knowledge will appear. Every piece of that knowledge could potentially become valuable both to consultants and at the company level.

\section{Discussion}

This section contains discussions from the static validation conducted and also a revisit to the initial research questions posed.

\subsection{Static validation}

The nature of proposed improvement suggestions calls for long-term evaluation at TestCenter, to provide extensive validation opportunities. Such would ideally involve several consultants in different projects and would thus require far more time than available during this study. Instead a static validation was performed to investigate the assumed applicability of the HotDog and its Test Experience Template. Since the industrial target with the study was posed by the Project Manager (PM) at TestCenter, a structured interview was conducted with him for validation purposes. Predefined questions within different applicability areas were created. Because of practical reasons it was not possible to include all consultants at TestCenter, which would have been preferable. However the project manager had large experience from working as a test consultant prior to project manager responsibilities. In total 14 open-ended questions covered four topics.

- HotDog - general about the concept

- Best Practices capture via TET's

- Introducing HotDog at the company

- Problem areas

By the results it was possible to see that the improvements suggestions were received very positively. The PM was convinced that the central approach of introducing HotDog for all test projects would decrease project learning times essentially and that this would lead to faster project staff relocations and increased overall staff mobility. Two contributing factors was believed to be that consultants could now prepare before relocation and that it could give them confidence in work.

It seemed that it would suit TestCenter better to focus update procedures to a few occasions near the start and end of participation in test projects, instead of having continuous updates like the author suggested. A potential risk with the few update occasions alternative is that information might be forgotten and lost.

Even though it was difficult to estimate the time consumption required for maintenance of HotDog, the PM was certain that the benefits in most cases would be larger than the cost of introduction and maintenance. It was described in the improvement suggestion report that HotDogs would not be feasible in all projects, and the PM supported this restriction. In case the test projects are short, or if it is certain that TestCenter involvement will not exceed one consultant, it would likely not be a beneficial solution, according to the PM.

Special attention was paid to the appropriateness of the Test Experience Template and its usability. The PM saw this as an interesting option and thought it would be valuable to both consultants for project learning purposes and for the company to extract knowledge from gathered experience. One risk with the TET part was that experiences could become widespread, in a sense that work with knowledge extraction could become complex. The PM suggested the division into more experience categories as a possible solution, however these need to be found by evaluating HotDog in real projects.

In total there were two issues identified that needed to be addressed before the improvement suggestions could be fully implemented:

- The question of whether the customer or TestCenter should take the economical cost of HotDog introduction and maintenance.

- The fact that not everyone enjoys writing documentation. The PM thought that the creation of update procedures and rules for required contents could decrease eventual problems with this.

The PM concluded that these were questions to be answered at a later stage and that a sharp trial of the HotDog documentation was the next step to take. The HotDog has been sent to one of the test consultants in 
a sharp resource consulting project. The purpose is to establish HotDog contents and evaluate if the information categories and TET are optimal, and in the next step to adjust contents and update procedures and distribute HotDog to several projects.

\subsection{Research questions revisited}

This study strived to answer four research questions. The answers can now be summarized according to the following:

1. What are the properties of test projects in TestCenter today?

Fourteen properties in software consultancy test projects were identified by conducting an industrial case study at TestCenter. There were properties which were common for all represented test projects, but there were a considerably larger number of variable properties.

2. What challenges do these properties present to the general work situation of test consultants at TestCenter?

Out of seventeen identified challenges, a total of nine seemed related to the identified project properties, all of which likely present challenges to the general work situation of test consultants. A factor with large effect on the general work situation is motivation. Some of the challenges seemed to contribute positively to overall consultant motivation and thereby work situation. The challenge "Purpose of Project Pl individual test cases hard to understand" was related to the fact that Project P1 enforced uninformed execution of test cases, predefined by a third party. This property had a negative effect on motivation in test work.

3. What challenges are associated with relocations between different test projects in consultancy companies?

Seventeen challenges could be identified from test consultant experience in project relocation contexts. Most of these concerned the learning processes of new test projects, out of which "Insufficient requirement represenentations" and "Insufficient time for preparation prior to relocation" were the most recurrent. Furthermore several of these challenges appeared to be caused by factors not specific for test projects. These could probably be generalized to project environments in other business areas as well.
4. What improvement efforts can be suggested in order to help test consultants relocate faster into newly assigned test projects?

Improvements suggestions were created based on the challenges of test project learning and relocation. The usage of a concentrated and consultant-administered documentation was proposed. A part of this documentation was dedicated to the gathering of tacit knowledge by using Test Experience Templates. Static validation of the improvement suggestions showed that the improvement efforts have promising potential and pointed to two issues that need to be resolved before dynamic validation. Initial usage in a sharp test project will help refine contents and the documentation maintenance process.

\subsection{Validity threats}

Since the study was not conducted as a treatment study, it should not introduce any single or multiple group threats. A threat to construct validity could be inadequate preoperational explication of constructs [21]. This is caused by somewhat vague initial definition of what a project relocation challenge is. Such could for example be either a social challenge, a technical challenge or some other type. In the study there was also a clear focus on challenges associated with project learning. While this could include both technical and social challenges, it might have lead to that non-learning challenges were not discovered. Furthermore, challenges were for the sake of improvement creations treated as obstacles, which is not the whole truth. Some challenges might, for example, increase motivation in a way that could offer more total value than mere reduction of project learning time. Another important threat to construct validity in this study is occurrence of mono-method bias [21], since only one method of experience extraction was used and only one researcher interpreted the material.

\section{Conclusions}

This case study has shown that there is an interest from the software consultancy testing industry to increase project staff mobility. Whether high project staff mobility is the best practice of HRM in test consultancy environments is uncertain. It is however likely a trend that will be visible in this industry in the 
future to come. The impact from frequent project staff relocations on test consultants needs to be further investigated. This study was unable to expose any signs that project staff relocations have a negative impact on attributes such as motivation. A number of challenges associated with test project learning and test project staff relocations could however be identified, as well as some that seemed related to general test work. With these as a basis it was possible to connect many of them to a common underlying factor; the need for knowledge distribution to consultants that join new projects. As a way to improve knowledge distribution, and thereby shorten consultant adaptation periods, a documentation solution was suggested to aid the learning of new projects. This approach received positive acknowledgements by the company involved, and the additional approach of using Test Experience Patterns to distribute best practices was also considered interesting enough to evaluate in a sharp environment. Questions that need to be solved by management are mainly related to the cost of spending time with documentation updates. It was however no doubt that the time saved by using the proposed solution would exceed the cost. An approach that showed promising potential was suggested in the form of experience templates for test consultancy environments.

\section{Future work}

We have in this study exposed some of the challenges that consultants experience when learning new software testing projects and when they are being relocated between them. Because of the relatively low number of participants in the study the results should be further supported in quantitative and more elaborate studies. In addition, future studies also need to evaluate applicability in test projects within traditional software development.

A larger understanding of the mental effects that frequent project staff relocations have on the staff will be relevant in order to create more deeply grounded theories. Future work is also needed to evaluate gains and costs of frequent project staff relocation practice.

Since the improvement suggestions posed were focused on a strict knowledge distribution solution, other solutions might be equally or better suited. Future dynamic validation of HotDog and Test Experience Templates would also contribute to research.

\section{Acknowledgements}

I would like to thank Dr. Robert Feldt most sincerely for the many constructive ideas given during this work. I am also grateful to Cybercom, more specifically to my advisor and to TestCenter management for believing in this work and for providing the best imaginable work environment.

Finally my special gratitude is given to my beloved parents for their inexhaustible moral support, which has contributed more than they think.

\section{References}

[1] J. Jurison, "Software Project Management: The manager's view", Communications of the Association for Information Systems, vol. 2, art. 17, 1999.

[2] S. R. Rakitin, Software verification and validation for practitioners and managers, London, UK: Boston Mass., 2001.

[3] D. Gelperin and B. Hetzel, "The Growth of Software Testing", Communications of the ACM, vol. 31, pp. 687-695, 1988.

[4] I. Sommerville, Software Engineering, Harlow, UK: Pearson Higher Education, 2004.

[5] P. Boxall and M. Steeneveld, "Human resource strategy and competitive advantage: A longitudinal study of engineering consultancies", The Journal of management studies, vol. 36, no. 4, p. 443, 1999.

[6] P. M. Wright and G. C. McMahan, "Theoretical Perspectives for Strategic Human Resource Management", The Journal of management, vol. 18, no. 2, p. 295, 1992.

[7] J. T. Delaney and M. A. Huselid, "The Impact of Human Resource Management Practices on Perceptions of Organizational Performance", Academy of Management journal, vol. 39, no. 4, p. 949, 1996.

[8] A. Belout and C. Gauvreau, "Factors influencing project success: the impact of human resource management", International journal of project management, vol. 22, no. 1, p. 1, 2004

[9] J. Söderlund and K. Bredin, "HRM in projectintensive firms: changes and challenges", Human resource management, vol. 45, no. 2, p. 249, 2006 
[10] N. M. Agrawal and M. Thite, "Human resource issues, challenges and strategies in the Indian software industry", International Journal of Human Resources Development and Management, vol. 3, no. 3, pp. 249264, 2003

[11] F. O. Bjørnson and T. Dingsøyr Torgeir, "A Study of a Mentoring Program for Knowledge Transfer in a Small Software Consultancy Company" in Product Focused Software Process Improvement, Heidelberg, Germany: Springer Berlin, 2005, pp. 245-256.

[12] M. Weiser and J. Morrison, "Project Memory: Information Management for Project Teams", Journal of Management Information Systems, vol. 14, no. 4, p. 149, 1998.

[13] C. W. Dawson, Projects in Computing and Information Systems - A Student's Guide, Harlow, UK: Pearson Higher Education, 2005

[14] D. A. Kolb, Learning Style Inventory: technical manual, Englewood Cliffs, New York: Prentice-Hall, 1976.

[15] Widgix Software. SurveyGizmo. [Online]. Available: http://www.surveygizmo.com.

[16] R. Feldt et al., "Correlations between Personality and Attitudes in Software Engineering", in submission, 2007

[17] L. R. Goldberg, "The international personality item pool and the future of public-domain personality measures", Journal of Research in Personality, vol. 40 , no. 1, p. 84,2006

[18] R. R. McCrae and P.T Costa Jr., "Reinterpreting the Myers-Briggs Type Indicator from the perspective of the five-factor model of personality", Journal of personality, vol. 57, no. 1, pp. 17-40, 1989

[19] G. Kotonya and I. Sommerville, Requirements Engineering: Processes and Techniques, Chichester, UK: Wiley \& Sons Ltd, 1998

[20] M. Bass et al., "Collaboration in Global Software Projects at Siemens: An Experience Report", in submission, 2007

[21] W. Trochim. Web center for Social Research Methods. [Online]. Available: http://www.socialresearchmethods.net. 
Appendix A - Methodology 


\section{A.1 INDUSTRIAL CASE STUDY}

This thesis project has been conducted and written mainly at the premises of Cybercom South. One of the purposes with this was that the author as researcher would have a wide access to persons and material that were relevant to the study. Another important aspect that was considered was the social one. While thesis project work was independent of Cybercom's own work processes, there were still possibilities to interact informally with staff at TestCenter, i.e. during breaks and even during arranged social activities. Even though such interaction might not directly relate to the thesis project, it could still have had a positive effect on the case study. Since the study was of qualitative and explorative nature, it was essential that TestCenter consultants accepted the researcher and thus had the will to offer their open-minded opinions. The gains of studies where the researcher becomes naturalized and accepted in the target environment in such a way is hard to prove and measure, but should not be neglected [22].

Cybercom South has kindly offered their assistance during the thesis project in every possible way and their only requirement posed on the study was to not pinpoint single individuals, products or customers. While the reason for the first-mentioned is obvious, the last two are natural in high-technology development environments and therefor we had to fully accept these requirements. The effects of this can be found in sections throughout the thesis report; i.e. no real-names have been used, no customer names have been mentioned and projects and products have been described at the highest possible abstraction level. We have tried to still keep the contents understandable for the reader. The full contents of the thesis report were reviewed and approved by the project manager at TestCenter before official publication. We are convinced that the level of details is sufficient to understand the core issues in the study. 


\section{A.2 DisCOVERING THE INDUSTRIAL AIM}

\section{A.2.1 Communication prior to thesis project start}

Before the start of the thesis project, some communication with the company occurred. Two meetings with the project manager and a test consultant within TestCenter were held. The first meeting could be seen as a presentation from and about the company, which additionally gave a rough description of the main concerns of the consultant relocation issues. The second meeting was more bidirectional during which ideas were further developed and put into a thesis context. It is however necessary to realize that these meetings were informal and initiated by the company. Although spontaneous notes were taken, these will not be presented in detail since they should not be considered part of the actual project conduction. A summary will however present the initial context discovered during these pre-project activities.

\section{A.2.1.1 Summary of communication prior to thesis project start}

While pieces of the overall picture of the company were given, the main outcome of these meetings was that the company imagined an expanded need of test consultant relocation ability to new projects. Part of the reason for this was the strong expansion that the company has experienced the past few years and the prediction of a continued one. One property of existing test projects that was believed by management to cause problems with consultant relocation ability was that every test project seemed to differ much from the other. A difference discussed by management in particular as being a troublesome one suggested the division of their projects into two types depending on their goals. The purpose of the first type was to find errors, and of the other to prove correctness. It was believed by management that the consultant relocation from a test project of correctness proof-type into one that instead called for error discovery was extra difficult. This was due to the beliefs that the latter requires an almost contrary state of mind in which exploration of the software needs to be actively encouraged. Since the possible usage of testing has been debated for as long as software has been tested [3] the industrial manifestation and realization of a potential problem related to them called for further investigation. During these meetings it also became obvious that the preferred interest from both company and academia was to view the consultant flexibility issue from the consultant perspective rather than from a resource planning one.

\section{A.2.2 Project Manager meeting}

After a work breakdown effort for the thesis project it became obvious that initial facts of actual company projects needed to be derived. There were two main reasons for this. Primarily the information was needed as a basis for understanding the context around the projects of the company and what basic influencing factors existed. Secondarily, the resulting concept orientation was considered valuable as could it improve communication during upcoming consultant interviews and thus resulting in gained knowledge through deeper discussions. Specific desirable information requests about test project details were distributed in advance (typical examples in Table A. 1), however the way in which this interaction point was conducted resembled a meeting or workshop rather than a structured interview. 
Table A. 1. Information request for meeting

\begin{tabular}{|c|c|}
\hline Area & Examples \\
\hline Project-specifics (for every project) & $\begin{array}{ll}\text { - } & \text { Customers } \\
\text { - } & \text { Time and duration } \\
\text { - } & \text { Responsibilities and staff roles }\end{array}$ \\
\hline Future concerns & $\begin{array}{ll}\text { - } & \text { Expansion areas } \\
\text { - } & \text { Desirable project types } \\
\text { - } & \text { Staffing }\end{array}$ \\
\hline Industrial aim for thesis project & $\begin{array}{ll}\text { - } & \text { Relocation background } \\
\text { - } & \text { Scope } \\
\text { - } & \text { Budget for implementation }\end{array}$ \\
\hline
\end{tabular}

Particular points of interest discussed during the first part of the meeting were specific information from each project including; customer, purpose of project, time and duration, development model, how many test consultants that were used, when during development TestCenter tested, what parts of the software were tested and in what way, i.e. function test, integration test etc. In addition documentation about each project was requested in order to enable information triangulation [23] to some extent. The second part of this meeting was used to discuss the industrial aims and scope of the study more closely. The meeting was held 26 June and external participants were project manager and the test consultant who would from now on function as the company advisor for the thesis project. The results from this activity are presented in B.1. 


\section{A.3 TEST CONSULTANT EXPERIENCE EXTRACTION}

The experience extraction from test consultants in TestCenter had two main aims for the sake of this thesis. One was to provide the research society with an insight to what the work situation for a test consultant looks like today, by seeking answers to the first three research questions posed. The other was to complete the understanding and formulation of the previously described industrial problem that needed directions for a solution. It could be said to serve directly as input to the process of finding feasible areas for improvement suggestions thus answering research question four. While meetings with the project manager of TestCenter had revealed the managerial strive and industrial aim, it was obvious that additional information from the concerned test consultants would be needed to find a solution to the problem. The reasons for this were both that some of them had valuable experience from previous relocations and also that they would indeed become the intended deployment target of any improvement suggestions. Regardless of whether identified improvement areas would focus on attitude changing, learning processes, information sharing or others, the test consultants would still become the actual end users. Like in software development projects, where requirements elicitation processes often gain from early involvement of end users [24], it was believed that so would this study.

\section{A.3.1 Information sought}

The scope of the extracted experience should cover experiences from several areas including;

- the learning processes of single test projects including routines, challenges, motivational aspects

- relocation processes between test projects as with learning processes

- supportive documentation test documentation availability and coverage

Furthermore, it was considered valuable to see if consultants could find any room for improvements with regards to these. Additional information about educational background and work experience prior to TestCenter could help put experiences in a wider perspective.

\section{A.3.2 Choice of experience extraction method}

Today many methods of extracting knowledge and experience are used by researchers and practitioners world-wide. Many of these methods have proven valuable and all of them have their own preferable area of application [22]. The ancient method of verbal inquiries known as interviews has been accompanied by several other approaches, of which surveys and ethnographical studies perhaps are the most well-known. Modern technology aid both quantitative and qualitative research efforts. By using telephone interviews researchers can access subjects around the world, and the use of internet-based surveys admits rigorous quantitative data to be collected. Common parts of research based on case studies can be divided into direct (interviews, questionnaires, observation) and indirect methods (studying relevant company documentation or reports) [13]. While no documentation or reports existed that were traceable to consultant relocation ability issues in this case, the choice of using direct methods remained. An observation method could probably be very useful given enough time. An advantage of observation could be that events are not enforced by the researcher, but occur and are recorded naturally [13]. Such a method could have been used for i.e. observing individual adaptation processes when a new consultant 
joined a project. The insecurity of whether this would occur often enough during the time-limited case study to collect more than one experience helped the decision that observation should not be the main method of experience extraction. Using questionnaires would not be feasible, mainly because it is a method associated with using a large number of subjects for quantitative purposes, and also that it would require many open questions which respondents would likely be reluctant to answer [13]. Instead the well-proven interview method which supports both open questions and a much higher response rate [13], should be used to effectively collect consultant experience. Because the thesis project was carried out at the company site face-to-face interviews were feasible. Additionally it was decided that a structured interview technique would be the most suitable, both because the author had only small experience of interviewing and that much information would need to be extracted during short interview sessions.

\section{A.3.3 Choice of subjects}

The approach for selecting consultants to use for information extraction evolved along with the awareness of the backgrounds of those in TestCenter. The team consisted at that time of nine test consultants including the project manager, who had more managerial responsibilities than test consultancy ones. He was naturally still considered to possess valuable knowledge. It was known that only some of the consultants had been relocated between projects, however all nine had experience from learning at least one test project and had, by this reason alone, a certain value to the study. Even though consultants with previous relocation experience could likely contribute more directly to the core problem of staff mobility, those with experience from only one project could be equally important. The more experienced consultants of the latter type could have developed a deeper understanding about what type of information is essential for newcomers, and those with less experience would contribute with fresh experiences from learning a project.

By this reasoning it became obvious that all nine consultants had potential to contribute with some valuable experience. An additional advantage with inviting all consultants was that this would prevent any team members from feeling unfairly treated (left out), which could in worst case, create tensions in the team. Realizing and minimizing the impact that each study has on the studied society is important with regards to research ethics [22]. This did not mean that all interviews were regarded equally important. Because situations in practical life (and certainly in the IT business area) change frequently, it would have been naive to not allow for a certain subject dropout rate. The plan was therefore to interview all nine consultants but with a bare minimum of three, since this would still allow for some degree of information triangulation. A more detailed prioritization of interviewees implied that at least one with relocation experience, one with massive experience from one project and preferably one newly employed consultant should participate. A second consideration was that each project of those described in section B.2 should preferably be represented by the voice of at least two consultants for triangulation purposes.

A comparison between the planned interview period and the company summer vacation schedule indicated that all consultants but one would be available for interviews. It should also be noted that during the cause of interview planning and conduction several new employees joined TestCenter. These were not included at this point because they were not believed to add a significant experience to the case study, especially since they all joined the same project. Additionally, the time budget of the thesis project plan called for a strict interview deadline. 


\section{A.3.4 Interview planning}

The project manager was kind enough to allow for interviews with as many consultants in the team as needed. Maximum duration of each interview was agreed to be one hour, thus careful planning of the interviews would be required. As much and relevant information as possible needed to be extracted within the given time frame. This influenced the process of creating interview questions, the usage of estimates of answer durations and also resulted in that time checkpoints were used for the sake of a pilot interview. The order of different interviews was considered to be irrelevant to the study but attention was still paid not to let knowledge from early interviews bias later interviews by conducting each interview with a reset mind.

\section{A.3.4.1 Creation of interview questions}

Before creating the topics and interview questions that would guide the interviews there were several decisions to be made. One possible way of conducting the interviews would have been to tailor each interview towards each consultant depending on his or her individual background. The drawback with this was that it would likely present large problems when gathering the individual experiences. Another alternative was to let all consultants answer the same questions. While this would likely result in a more uniformly formatted set of answers, it would also mean that the value of differences in experience could not be fully used.

As a result a hybrid solution was used where interviews contained a background part, a project-specific part and a relocation-specific part. The background part involved questions about education and previous work experience and was answered by everyone. The project-specific part meant that each consultant answered questions about one project. These were selected to fit requirements from A.3.3. The projectspecific part was arranged in two levels, the extended level carrying questions concerned with experiences from test documentation. Because the relocation specific part in the end of the question collection could only be answered by those that had previously changed projects, the others were asked questions from both levels in the project-specific part.

Common best-practices were followed in the construction of questions, such as avoiding accusation-style questions starting with "Why?" and varying the degree of openness in the questions [22]. The questions that were actually used are presented along with individual rationales in C.1. 


\section{A.4 CONSULTANT LEARNING STYLES AND PERSONALITIES}

\section{A.4.1 Purpose}

In order to create interpretation support for the results from the interviews conducted (C.2) the intention was to use surveys that could reveal more about the underlying personality factors from the interviewees. While such tests would not create a relevant significance because of the few respondents, it was still interesting to see if any obvious patterns or correlations with interview results would appear.

\section{A.4.2 Learning style test}

Because the learning of new test projects was of large interest to this study, a conduction of a learning style test was interesting. One of the most accepted is the LSI, Learning Style Inventory, created by Kolb [14]. The theory behind LSI is that the learning process of individuals can be described as a cycle that spans over two learning dimensions; Abstract/Concrete and Active/Reflecting. This division creates four quadrants, which in a learning process are visited iteratively and clockwise (see Figure $B$. 2). A typical example is that a person acquires experience by working actively in a team (Accomodating style), he can then discuss and theorize about the results together with the team (Diverging style), continue to reflect on his own (Assimilating style) and try the newborn knowledge actively on his own (Converging style). According to Kolb, each individual has a special preference for a learning quadrant which can be determined by letting respondents compare the values of nine sets of words. The LSI has been criticized by some, mainly because it only shows relative difference between learning factors in an individual. It was argued that this disables a direct comparison between respondents [25]. In the context of this study however, such comparison was not relevant since the intention was to either look at individual results or the result as a whole thus not comparing single individuals with each other.

\section{A.4.2.1 Learning style test methodology}

The LSI test is an administratively easy test to manage. Within nine groups of four words the respondents basically prioritize the four words by associating them with the numbers 1-4. Results are summarized according to a score table (Table B. 4), which indicates a value for each LSI quadrant. The result can then be plotted in a diagram by subtracting the values for each dimension (Active-Reflective and Abstract-Concrete). An alternative display method is possible where each of the four quadrant values are plotted on the axes and connected with lines. The latter approach shows a more detailed picture of each respondent. For the sake of this study, it was considered more appropriate to gather respondents in one diagram which suggested the first method of result display would be the most appropriate.

The LSI test was hosted by an independent and free internet-based survey company [15] and the original words were translated carefully to Swedish since it was the native language of all respondents. This method allowed for the respondents to participate whenever they had time left, spanning over a period of several weeks. When the survey was finished, participants were sent their individual results together with explanations and links to further reading should such interest exist. In order to preserve anonymity, all mails were sent within the local mail server of the department, which offered mail encryption. Overall learning style results are presented in Figure B. 2 . 


\section{A.4.3 Personality test}

There were two reasons why a personality test should accompany the learning style test. The first was to give support to the study if inconsistencies were found in the learning style survey or in the interview data. Additionally, research by Feldt et al. [16] has shown correlations between personalities of software engineers and the manner in which they work in software development projects. Even though our study would not yield statistically significant results, it was interesting to compare personalities of test consultants with software engineers.

Feldt et al. compare in [16] different personality tests and chooses the IPIP 50-item test for several reasons. Examples are that they describe personalities better than other tests, they allow for statistical analysis by using numerical values and they are free for use. By using the same personality test as Feldt et al., a comparison would be possible and at the same time without any cost. The scope of IPIP 50-item test [17] was also sufficient to the relatively small impact the test would have on this study. IPIP tests are used to measure personality using the five-factor model [18], which shows personality based on five important personality dimensions found by empirical research. These dimensions are; Openness, Conscientiousness, Extraversion, Agreeableness and Neuroticism. A computerized implementation of this test exists on the internet [26]. The online version is free for everyone to participate in, resulting in a massive personality database over reasonably random respondents. In [16] a direct comparison with the database results is discouraged, since the online version uses a different number of items for each test factor. It is however uncertain how large the difference between this IPIP version and the IPIP 50-item version is, and Feldt acknowledges the possibility of comparing for indicative purposes [16]. In the results section both Buchanan and Feldt results will therefor be displayed together with the results from this study.

\section{A.4.3.1 Personality test methodology}

As with the LSI test, IPIP 50-item is relatively easy to administer. While both the respondents in the Feldt test and in this study were Swedish the same set of previously translated questions would be preferable to use. They were kindly supplied and authorized for use in this study by Dr. Feldt . The use of identical questions enabled a comparison between these two studies. The IPIP 50-item test was then bundled together with the LSI test and ran simultaneously as described above. When the survey was closed and results had been calculated they were individually sent to the respondents together with explanations and links to further documentation. As with the LSI results, these mails were transported strictly within the department, using a local mail server with encryption support. The overall result is presented in Figure B. 3 . 


\section{A.5 IMPROVEMENT SUGGESTIONS CREATION}

This section reasons about different approaches that could be feasible as improvement suggestion areas in order to answer the fourth research question; "What improvement efforts can be suggested in order to help test consultants relocate faster into newly assigned test projects?" The actual choice of improvement suggestion area to focus on and the creation of improvements suggestions are also motivated.

\section{A.5.1 The impact of project staff relocations on other parties than consultants}

Up till now we have focused on how previous test project staff relocations were experienced by consultants and the difficulties in learning new test projects, thus by studying the results appendix (Appendix B) we can now see some of the areas that need to be improved in order to create faster project staff relocations. There is however other parties that are affected by consultant project relocations as well which have only been mentioned briefly. To TestCenter management consultant project relocations will have a central role in the evolving TestCenter Model (Appendix B). It will mean consultants can be made more mobile in resource planning, offer larger productivity and better cost efficiency since less time needs to be spent on project relocation issues. There is however also an impact of these frequent relocations to the customers TestCenter work for, be it Cybercom itself or external customers. There have for instance been concerns that frequent consultant project relocations can have negative influence on the customer relationships, because they want one specific contact person to turn to during a project. Such experiences and concerns could indicate a need to further evaluate the idea behind TestCenter Model and the way it will be practiced. The purpose of this thesis is not to do that, but to present ways to practically improve staff mobility in a way that supports the TestCenter Model. The parties that are concerned are however important to take into consideration when improvement suggestions are created.

\section{A.5.2 Candidate approaches to improving consultant project relocations}

\section{A.5.2.1 Improved requirements representations}

One of the most common experiences related to project learning was regarding poor requirement specifications. Requirements had often been poorly described or were outdated. Since TestCenter commitment has often been to test functionality on the system level, the existence of well-specified requirements is vital. If TestCenter was only involved in Cybercom in-house development projects, the main aim for improvements suggestions would without doubt be to investigate and improve requirements practices and representations. However, the nature of test consultancy does not often allow for TestCenter to control the ways in which requirements are presented. It would seldom be feasible to demand from customers to change their requirement practices. Neither would the alternative of letting TestCenter consultants create and maintain requirements representations of their own be a ultimate, general solution. It is possible that some type of high-level requirements structure such as graphs or trees [19] could aid this problem however there would still be large time loss on creation and maintenance of this representation. 


\section{A.5.2.2 Longer introduction periods before relocation}

If consultants were given more time for preparation before actual project relocations they would require smaller learning periods after relocation. While this approach would not actually shorten the total learning period, it would move it in time so that less time was borrowed from the new project for learning purposes. This could have a positive effect on the customer since new consultants would have knowledge before they set foot on site. There are however at least three implications;

- Time would instead be taken from the old project, thus having a negative impact on contribution and customer relationships there.

- Given the current state, such introduction would require that another consultant would need to verbally transfer knowledge to the new consultant, thus even more time would be taken from the new project. Resource management would become a difficult task.

- According to C8 much content of new projects needed to be learned by observation and could not be taught off-site.

\section{A.5.2.3 Simultaneous introduction periods}

By letting several consultants participate in a common introduction phase the total learning time per consultant would be shorter than during isolated introduction. Unfortunately it is not known from the beginning how many consultants are needed in each project. The nature of test consultancy could for example mean that TestCenter is not contacted until the customer realizes that it has not enough test resources on its own. Neither is it possible to predict the need of resource growth or decrease during each project.

\section{A.5.2.4 Documentation approach}

If consultants were able to write down knowledge of projects during their course, a documentation solution could be used by other consultants that joined the project later. Seven out of ten identified learning challenges are concerned with information distribution and if documentation existed as a complement to learning via direct communication, information distribution would likely be more effective and project learning periods shorter. The learning challenges concerned are;

- Knowing who to ask

- Not to disturb others more than necessary

- Learning existing customer product (software+hardware)

- Learning customer terminology

- Knowing where to find information

- Distraction from learning new project because receiving questions about an old project.

- Insufficient time for preparation prior to testing

In addition there would be other advantages;

- Documentation is reusable and will reduce the time required by customer or other TestCenter consultants to answer the same questions from different TestCenter consultants

- It is possible to prepare an upcoming relocation by using only little time in advance, thus we will have an optimized version of A.5.2.2, possibly with improved customer impressions as a result

- Documentation is not limited to introduction usage, but can be used during the whole course of a project to serve as an information center and possibly a knowledge repository. 
- Could offer future opportunities for TestCenter to analyze experiences from projects, post-mortem

- Will reduce the problem of knowledge that leaves projects when consultants are removed from them.

The largest problem with a documentation approach would likely be that it needs constant updates during the course of projects. We have seen before (C7 interview) that customer sometimes react negatively to the study of documentation since it does not produce an obvious and direct output. Another prerequisite is that management is willing to actively promote and

\section{A.5.3 Creating a structured documentation}

Out of the mentioned candidates the documentation approach made the most sense to focus on. There is also an additional reason why a documentation solution should become accepted and used by the target consultants. Many of the consultants have worked in project P1 and are already familiar with using and maintaining documentation with similar characteristics; the LazyDog. While the LazyDog contains specific step-by-step instructions and tips and tricks for a specific project, the documentation proposed in this study is more generally applicable to the whole test environment in different test projects. However, the main philosophies that consultants themselves are responsible for updating the documentation and that everyone can contribute are the same in both these approaches. It is important to realize that the LazyDog has evolved naturally from the requirements from actual work conditions and not as a planned formal document. This is a clear indication both that documentation is valuable and that there is a will among the consultants to codify their knowledge so that it can be reused.

Due to the time factor being extra sensitive in the consultancy context, it was decided that the proposed documentation solution should be as short and concentrated towards reducing the challenges described in Table B. 3 as possible. A process where the consultants on a weekly basis used fifteen minutes to update documentation was considered appropriate and to have small impact to a 40 hour work week. Support for fast update procedures was important, and as a result it was suggested that TestCenter as a first approach should use the suggested word processor template during a trial period. The reason for this was that a flexible documentation template was highly desirable in order for TestCenter to adjust and extend the exact contents with little effort. Even though a web solution was later proposed because it has many additional advantages, the idea was that the evolution of documentation contents were initially a better focus than a technical solution. Considerations about a web solution as hosting platform are discussed more closely in D.1.2. In Appendix D the documentation structure is also presented (Figure D. 1. HotDog principal structure and process) and was converted into text fields and tables in the document format of the standard word processor program used by TestCenter. The choice of Reference literature to use initially is described below. In addition to providing TestCenter with the actual document template, a fully implemented, fictive example was included. Since these files require special software to view, they have been exchanged with screen dumps in this report (D.1.7). 


\section{A.5.3.1 Reference literature choice}

Table A. 2. Reference literature choice

\begin{tabular}{|l|l|}
\hline Title & Purpose \\
\hline $\begin{array}{l}\text { A Comparison between } \\
\text { Agile and Traditional } \\
\text { Software Development } \\
\text { Methodologies [27] }\end{array}$ & $\begin{array}{l}\text { Testing process is much dependent on } \\
\text { the development methodology used. } \\
\text { Room to extend the knowledge of } \\
\text { development methodologies were } \\
\text { identified during interviews. This is a } \\
\text { straight-forward overview of common } \\
\text { methodologies. }\end{array}$ \\
\hline Software testing [28] & $\begin{array}{l}\text { Small overview of test methods and } \\
\text { levels relevant to TestCenter, such as } \\
\text { Blackbox and System testing. }\end{array}$ \\
\hline $\begin{array}{l}\text { What is software testing? } \\
\text { And why is it so hard? [29] }\end{array}$ & $\begin{array}{l}\text { Thoughts about difficulties with Test } \\
\text { coverage and good practices on } \\
\text { achieving. }\end{array}$ \\
\hline $\begin{array}{l}\text { How to design practical test } \\
\text { cases [30] }\end{array}$ & $\begin{array}{l}\text { Practical tips from Hitachi on } \\
\text { designing test cases }\end{array}$ \\
\hline
\end{tabular}

\section{A.5.3.2 Knowledge reuse with experience patterns}

The major part of the documentation structure is based on information types that are relatively easy to codify, explicit knowledge [31] (i.e. contact persons, terminology, processes and examples). While these can contribute to an understanding of processes and reduce project introduction periods they do not aim directly for so called tacit knowledge extraction.

Since the topic knowledge management has grown to be a major one in the research society during the recent years, the term tacit knowledge has become a major concern since its introduction already in 1962, and is today described as the most difficult type of knowledge to understand [32]. Tacit knowledge could be defined as knowledge of the hand, implicit knowledge, knowing "how to do things", and is often created by experience. The authors of [32] identify two major camps in the debate of to which extent it is possible to codify tacit knowledge and thus converting it from being implicit to explicit. One supports the idea that all knowledge can be codified at a cost, even tacit, and can thus be a complete substitute for tacit knowledge. The other claims that all types of codified knowledge depend on tacit knowledge itself in order for the interpreter to make sense of it. As researchers struggle to discover the secrets of tacit knowledge different approaches towards taming tacit knowledge have been made. One of these is [33] in which an approach of using agent systems for determining which intranet documents is interesting to a certain user group was made. One of the key points discovered by the authors was that tacit knowledge might be communicated through IT systems without the need for expressing it explicitly. With this in mind we investigated another practical example, [20]. In this paper it is described that Siemens used what they call Best Practice Templates in order to gather tacit knowledge into best practice patterns. While these were related to the nature of Siemens global software development projects parallels can easily be drawn to Test consultancy environments as well, in which single consultants in different test projects could be compared to a software team abroad. This lead to that a novel approach of using similar templates for test consultancy contexts were used, the Test Experience Template. While some of this template content was borrowed from Siemes Best 
Practice Templates, some was new. The detailed form of the Test Experience Template is described in D.1.3.4 and Figure D. 4. 


\section{A.6 Static Validation}

In many case studies, including this one, there is an obvious gain in acquiring feedback from the environment studied [22]. One reason is to validate if overall gathered impressions have been correctly described and analyzed. Another can be to find out if actions taken have had the desired effect on the environment. In a case such as this, it is not possible to investigate results from proposed suggestions, because the suggestions presented have simply not yet been implemented. Even if ideal conditions had existed and suggestions could have been implemented during the course of the thesis project, a long-term solution such as this would need to be practiced in several full length projects in order to produce enough output to correctly determine its feasibleness. It was still considered meaningful to conduct a static validation by asking for an early evaluation. Results from such a validation could give early indications of what aspects are missing, which have been incorrectly described, and describe a path for future work.

In this case there was a primary concern of what impact the proposed improvement suggestions was believed to have if they were implemented. Specific concerns for this thesis were;

- Would the project manager see the same gains with the suggested documentation solution as the author did?

- Would the project manager consider the solution to be cost effective enough?

- What ways could the documentation solution be improved before implementation?

- How would the project manager relate to the more abstract section of Best Practices, and the idea of using test experience patterns?

- Could the pattern template be modified to better suite Test Consultancy environments?

In order to find answers to these validation areas a set of interview questions was designed (Table E. 1). The improvements suggestion report (Appendix D) was sent to the project manager and an interview was scheduled a week later according to an agreement. This time was by both considered enough to read and evaluate the material sent. Data from the static validation interview can be found in Table E. 1 and a relevant discussion in B.5. 
Appendix B - Results 


\section{B.1 Results From Project MANAger Meeting}

The outcomes of the meeting (A.2.2) were divided into several subsections due to practical reasons. Characteristics of the test projects that the company has conducted are discussed in section B.2, while information about industrial aim and scope formed section B.1. It should be noted that no detailed documentation about test project specifics was available. The contents of this section have been reviewed for authenticity by the project manager.

\section{B.1.1 Industrial aim of thesis project}

\section{B.1.1.1 Company information}

Cybercom is a group of IT consultancy companies with specialization in software development in high-technological areas. In addition counselling and services within areas such as telecom management and networking are offered. The company group was founded in 1995 and has been continuously expanding since. Today the company has more than a thousand employees in six countries with Sweden as base, providing worldwide services [34].

The department TestCenter belongs to the regional company Cybercom South AB and has the main responsibilities for software validation and verification (V\&V). Projects undertaken by TestCenter range from resource test consulting in customer development projects to V\&V supporting pure in-house development. Responsibilities range similarly, from strict test execution and reporting to full test project ownership.

\section{B.1.1.2 Expansion and predicted future needs}

During the Project Manager Meeting the project manager of TestCenter was asked what was in the future for the test department. The answer was continued growth and he hoped specifically for an increasing number of test projects. He was invited to give details if there were any specific desirable attributes of such projects, such as project size and what type of customers were preferred. While these two seemed of less importance, one preferred attribute was instead to have a larger share of in-house projects. The main reason for this has to do with something the project manager referred to as "The TestCenter Model".

\section{B.1.1.3 The TestCenter model}

The workload during test projects at TestCenter often appears as short bursts, especially if only partial responsibility for testing activities exists. Another example of the manifestation of this phenomenon is during and between test executions related to incremental releases of agile development projects. In order to have a more continuous workload each test consultant should ideally be able to relocate more or less frequently between different test projects. This principle of resource management is moderately practiced today but it is also the vision of company management that it has a larger importance in the future as the number of test projects increase. Management has invented the name TestCenter Model to describe it. It is believed to be vital that test consultants support this way of working and the flexibility that it requires.

\section{B.1.1.4 Consultant project relocation ability}

As mentioned in B.1.1.2 the project manager embrace in-house test projects. (Note that the term in-house in this context means that testing activities are conducted in the premises of TestCenter, thus should not be confused with development 
ownership.) One reason for this was that in situations where Cybercom South consultants at customer sites have been exchanged, the customer sometimes seemed dissatisfied over not having the same consultant present during the whole project. While this is not a major problem, it is still a situation that possibly could improve by creating support for fast consultant relocation processes into new projects. If such existed it would likely result in shorter learning processes for consultants relocating to a new project. Not only is this believed to reduce customer frustration by demonstrating new consultants as fast and effective learners. More importantly consultants could use more of their energy for the task itself and have improved flexibility, which would work well in hand with the TestCenter Model now and in the future. There could also be economical advantages of improving such project staff mobility in form of reduced mentoring periods. Today when a consultant is introduced to a new test project at Cybercom South he initially works next to a more experienced one. In situations where several consultants joins the same project and asks the same question, the high cost of mentorship can become visible.

\section{B.1.1.5 Aiming to improve project staff mobility}

Cybercom South $\mathrm{AB}$ wants to investigate if it is possible to improve project staff relocation ability from consultants and thus increasing staff mobility as described above. The expected outcomes of such an investigation are guidelines, methods or alike, that could be used for this purpose. The cost of implementing such guidelines later is of less importance to Cybercom South at this time, and it is feasible for the investigation in this thesis to present whatever improvement proposals seem fit. 


\section{B.2 TEST PROJECT PROPERTIES}

Section B.2.1 presents the information regarding test projects that was received during the Project Manager Meeting (A.2.2). Because information has been interpreted by the author, it has also been reviewed for authenticity by the project manager. Section B.2.2 extracts such properties of the described projects that are likely to indicate different aspects of consultant flexibility needed.

\section{B.2.1 Previous and current projects}

In this section the four major projects undertaken presently and historically by TestCenter are presented. For the sake of confidentiality project names have been translated into a plain number that indicates the order in which they are presented in this section. They have also been abbreviated with the letter P for Project.

\section{B.2.1.1 Project 1 (P1)}

This is an active continuous test project that has been running for more than two years. The purpose is to test functionality in the embedded software of a certain device type. Devices containing this software are released to market every month in average. The customer is a major manufacturer of this type of devices. Cybercom South responsibility is functionality testing by executing customer specified test cases in several modules in their software. The different modules tested are independent of each other and could to a small degree be viewed upon as multiple test projects. If compared to the classic V-model of testing [2] Cybercom South testing is conducted at the System or Acceptance level. While both these validate software requirements, Rakitin distinguishes the two mainly by the environment in which they are conducted. According to him acceptance level testing is conducted in the actual target environment. Because all devices under test in P1 are both handheld and stand-alone units it could be argued that the test level is acceptance test. This is because any test location outside of the manufacturing department (such as the TestCenter) could serve as sharp target environment. With favor to declaring the P1 project as system level testing instead is that the devices must be hardwired to measuring tools in order to fully test all behavior. It should be remembered that the V-model is not an authoritative classification system but only a universal model of testing activities that is being widely used and referenced. An absolute positioning of test projects into it is by this reason not necessarily appropriate and should in this context only be seen as guidance.

There is one main property of P1 testing that distinguishes it from the rest of TestCenter projects according to the project manager. Because TestCenter is only involved in the very last part of the software development their responsibility here is not to primarily find errors but on the contrary to prove their absence. For one of the modules this is done by generating logs from certified test programs supplied by the customer. The logs are then sent to a certification authority which rewards the device with a specific licence required before device release. If a specific test program fails to produce the correct log the problem is most often that some of the very detailed test settings are incorrect and very seldom that an actual software error has been found. The challenge of this work is according to the project manager more likely to be the choice of an appropriate test method rather than to investigate problems with a software construct. Furthermore, the project manager believed it could become especially troublesome for consultants to relocate from this type of project. The motivation was that $\mathrm{P} 1$ test work encourages consultants to find ways of proving correctness while other projects require them to actively look for and often investigate software errors. Another unique property of P1 is, according to the project manager, that the release deadlines of devices are never postponed. Instead, the size of testing effort for each device may be adjusted by the date of test initialization and the amount 
of test effort during the test period. In most cases this means that if the code freeze date is postponed so that the test initialization becomes delayed, adjusting the number of test consultants associated with the project is the only practical solution. The experience from many previous device releases and the fact that the tests run are mostly predefined sets of regression tests help Cybercom South with resource planning in this project.

P1 is otherwise not involved in the software development of these modules. As a result they have limited knowledge of the development process, other than it is conducted as classic waterfall development [2]. This means P1 experiences workload bursts in the end of software development for each device, as this testing is an important part of the final testing before full device release. P1 engages a major part of the TestCenter team on full-time.

\section{B.2.1.2 Project $2(\mathrm{P} 2)$}

Close before the start-up of this study a major release version of a strategically important development project was finished. The product developed and improved during two years was a client-server solution meant for enabling devices to acquire certain media files. The customer is a manufacturer of the device type that was targeted. Cybercom South had full responsibility of development surrounding this product. Since development practices are based on an agile test-driven method [2], this meant that TestCenter had both a large responsibility and a close interaction with the in-house development team. Along development major and minor versions were released and introduced on both server and client side, mostly transparently to the end user. Because development was held in-house, all testing could also be performed inhouse TestCenter. Tests were of several types, including functionality, load, integration and regression testing [2]. Testing level positioning into the V-model is most likely not feasible but would place the P2 test project alongside the model, covering all levels for the eventual exception of acceptance level. From a consultant perspective $\mathrm{P} 2$ required both test design, discovery of errors and the back-tracking of them to software modules and individual modular functionalities together with developers. Because full test responsibility lay at TestCenter, test consultants were also responsible for test design and involved in activities such as requirements elicitation. As a natural result of the agile development method used in P2, one of its unique test properties is the frequently changed test specification. Despite the large responsibility of TestCenter during the $\mathrm{P} 2$ project, the technical product size only claimed one fulltime test consultant resource on average. The project manager is hoping for the next major release version of this product to be twice the size of the recent version. Even more resources from the TestCenter should be added since the recent version had a little too few. At current date the plan is to use several more test consultants and to also have a dedicated test manager in the next release.

\section{B.2.1.3 Project $3(\mathrm{P} 3)$}

This is a fairly new, active project with promising potential. The software tested is embedded in a different device type than then one in Project P2. While the customer similarly is the manufacturer of these devices, the $\mathrm{P} 3$ project differs in that TestCenter at this early point mainly contributes as resource reinforcement in the testing process which is otherwise fully owned and controlled by the customer along with the full development process. One TestCenter consultant is currently working on P3, but the project manager at TestCenter hopes that this project will expand and enable TestCenter to gradually take larger responsibility for the testing process. One possible future situation is where both the customer and TestCenter would participate with one project leader each. The activities that the test consultant has participated in this far includes most parts of the test process, i.e. specification, design and execution of tests. 
An agile incremental development method is used, which has among other resulted in that the test consultant has worked in different stages of development including requirements engineering. The agile method is not the same method as in P2 but has similarities. The most common test type has been system test, although others such as unit, integration, functionality and acceptance testing have occurred. The project test team has in addition to the TestCenter consultant consisted of a handful of test engineers employed by the customer. The most outstanding property of project $\mathrm{P} 3$ is that process control is currently not in the hands of TestCenter. Another property is that this project, although it is promising, is not yet fully stable with regards to the future role of Cybercom South.

\section{B.2.1.4 Project $4(\mathrm{P} 4)$}

$\mathrm{P} 4$ was a project that was active prior to projects P1-P3. The only person involved in this project that is still active within TestCenter today is the project manager himself. However, since he did not have the test project manager responsibility at the time of P4, existing information about this project is not fully extensive. The product developed was a device software updating service and Cybercom South had full development responsibility including responsibility for test management. The customer was a large manufacturer of these devices. An agile method was used for product development and, alike P2 and P3, also meant incremental development. Tests were mainly of integration and functionality type and resource usage was estimated to two part-time consultants. Testing was conducted in-house and mainly in the end of each development iteration.

\section{B.2.2 Properties}

The purpose of collecting information about historical and current projects of the company was to present the work field that test consultants meet today and to find properties that indicate what sort of consultant flexibility is required. Presented in section B.2.1 are four projects that, when analyzed, show a large diversity in project characteristics with regards to several properties. There are of course an infinite number of dimensions in which one could find series of properties to characterize a series of projects. It is also inevitable that some project characteristics can not be extracted this way since different consultants experience projects in different ways. As none, or few real-world analyses could righteously be called complete, this section presents visible properties of the described projects in a way that corresponds to common state-of-the-art terms and concepts.

\section{B.2.1.1. Properties with low or no variability Prop1. Embedded software All projects have been associated with software of embedded type, at least partially. \\ Prop2. Manufacturing customer (hardware devices) Cybercom South has been working directly for the companies that manufacture the devices, i.e. not through intermediate software providers \\ Prop3. Agile context}

All listed test projects in which Cybercom South has been involved prior to acceptance testing have been in agile development contexts. 


\section{B.2.1.2. Properties with high variability}

Prop4. Different target platforms

There are at least two completely different device types involved in these projects, in addition to server solutions in client-server systems.

Prop5.

Ultimate purpose

Naturally, two projects seldom have exactly the same purpose. However, there is a large difference between the purpose in $P 1$ and the rest of the projects since it does not invite test consultants to look for errors, but to find ways to prove their absence.

Prop6. Test activities

Consultant activities are normally a subset of test activities in a range from test execution to test planning.

Prop7.

Prop8. Test levels/Test types

Software is tested on subsets of test levels described by the classic V-model [2], ranging from unit testing to acceptance testing, Test types include functionality, load and regression testing.

Development involvement

The degree to which the testing process interacts with the development process. Ranging from minimum interaction as acceptance testing in the end of development, to full insight and involvement from requirements eliciation to release.

Prop9. Process ownership Cybercom South has a specified amount of responsibility over testing and development processes ranging from resource relieving to full ownership.

Prop10. Physical location In each project consultants are either stationed at the customer site or in-house Cybercom TestCenter.

Prop11. Size of TestCenter staff Ranging from a single consultant to a handful of consultants per project, thus offering different opportunities of internal learning processes during projects.

Prop12. Project documentation dynamics Projects with agile background (Prop2-Prop4) are more likely to change frequently during their lifetime because documentation is often adjusted along the way and do not constitute preset rules [35].

Prop13. Project stability

New projects or projects that by other reasons are not stable are more likely to introduce unplanned relocations of test consultants.

Prop14. Test project length The duration of test projects have ranged from six (6) to eighteen (18) months.

\section{B.2.2.1 Properties discussion}

The low variability properties could in some sense be seen as a subset of properties that actually reduce the need for test consultant flexibility in Cybercom South. In current and historical projects it has likely been useful if the consultants have aquired 
at least general knowledge about these three (Prop 1-3) before actively working with any Cybercom South test project. It should however also be noted that project management has expressed no desire to limit future projects to including these properties.

The numerous variability properties can be assumed to span a room with multiple dimensions that holds many aspects of required consultant flexibility. It would be possible to divide the variability properties into higher-level categories, such as Technical properties (Prop 4-7), Structural properties (Prop 8-11, Prop 14) and Project dynamics (Prop 12-13). At this stage we should however be careful not to make abstractions that move away too far from the detailed properties. The reason for this is that the overall picture created if we did, would probably not fit the picture that TestCenter consultants have. It is also likely that relationships between properties in different high-level categories would become hidden. The purpose of this part of the case study is to present an initial list of low-level project properties that are likely to call for consultant flexibility. At the next stage consultant experiences will be investigated to see which listed or unlisted properties seem to create actual test consultancy and project staff relocation challenges. 


\section{B.3 CONSULTANT EXPERIENCES}

This section contains discussion and analysis regarding interviews made for the sake of experience extraction. The main source is the Interview answer log (C.2). Analysis will begin with backgrounds and experiences of each consultant and continue with increasingly abstraction to analysis of gathered experiences at project level and finally at a cross-project level, which also represents the level closest to relocation issues.

\section{B.3.1 Conduction of interviews}

A total of eight interviews were conducted in the case study. As mentioned in the methodology part (A.3.3) the ninth consultant was unreachable during the study. The first interview was conducted with the project manager who, even though he now had other responsibilities, still was considered to have valuable experience from test consulting. It can be discussed whether this interview could become biased with administrational issues and not strictly represent a consultant's view. To compensate for this potential risk, it was decided in advance that a more critical evaluation would be appropriate when comparing the result with the other interviews. This interview became the pilot interview, and it turned out both that the time estimations were satisfactory and that the questions worked rather well. After this interview the seven others were conducted within two weeks time. This was considered positive since the interview period partly interfered with the Swedish summer vacation period.

Most interviews were made in the local conference room in order to minimize tensions by using a neutral environment and a few were conducted in the temporary work room of the interviewer. All interviews started with a common presentation part from the interviewer, including an expressed appreciation for the participation, an explanation about the purpose of the interviews, an assurance about anonymity and the possibility to ask the interviewer questions regarding the interview and study. The interviewer then proceeded with asking questions in a structured order and when needed asked spontaneous sub-questions depending on each answer given. Notes were taken manually on paper and have been translated to English without any analysis or modification and moved to digital form, which is presented in C.2.

\section{B.3.2 Individual summaries and analysis}

\section{B.3.2.1 Summary of $\mathrm{C} 1$ interview}

Consultant $\mathrm{C} 1$ has worked with testing in Cybercom for 36 months, all in TestCenter. $\mathrm{C} 1$ now works as project manager for TestCenter thus has managerial responsibilities rather than test consultancy ones. The educational background of $\mathrm{C} 1$ is civil engineer degree at university and no software test specific education. $\mathrm{C} 1$ thinks learning more about test types would be advantageous (performance, load and exploratory testing). $\mathrm{C} 1$ has worked with three projects during this time. As $\mathrm{C} 1$ was the first test consultant in both of the projects $\mathrm{C} 1$ gave information about. Generally, motivation of $\mathrm{C} 1$ during these projects seems to have much to do with the fact that $\mathrm{C} 1$ was the first test consultant involved in them, giving that $\mathrm{C} 1$ was on unexplored territory, "Everything was new". Another motivating factor was to participate during the whole development process in both projects (which both were in-house projects). The work of $\mathrm{C} 1$ in these projects did also feel creative, especially to "find different ways to execute to pinpoint an error". Regarding the relocation between projects C1 saw it only as something positive, a "great challenge", and especially since C1 got the responsibility of test leader. A challenge in relocation was that $\mathrm{C} 1$ was "thrown in", thus not having much time to prepare or have a proper introduction. Developers can be asked questions but only to some point because of two reasons. 1) You have to know 
who to ask, and 2) You do not want to bother them in their work. There was no documentation at all when $\mathrm{C} 1$ came to Project $\mathrm{P} 2$ (except for erroneous requirements) and $\mathrm{C} 1$ had too little time to create any (working part-time).

\section{B.3.2.2 Analysis C1 interview}

It is visible here that the biggest challenge that $\mathrm{C} 1$ faced when relocating between projects was that there was not enough time. If more time had been given $\mathrm{C} 1$ would probably had been able to i.e. participate in development meetings or having thorough system overviews before testing sharply. As there existed no project nor test documentation to take part of, $\mathrm{C} 1$ had still not been able to start the project learning period on C1's own before being "thrown in". Instead the adaptation period for C1 consisted of asking developers whenever knowledge about the system was needed. C1 identified two possible difficulties with this; knowing which developer to ask (indicating a certain lack of relevant contact information), and the risk of disturbing developers. Even provided developers were helpful and could give good answers, it would still mean they sacrificed valuable time. It is also likely that the first person asked would not possess all relevant knowledge to answer a specific question completely, and that developer time would (at least before all developer responsibilities and competences were learned) be spent in vain, only to redirect the test consultant to another developer. It should also be remembered that Project P2 was an in-house project, meaning that a corresponding project conducted at customer location could introduce political disadvantages as well, with asking numerous ad-hoc questions. Motivation of $\mathrm{C} 1$ was preserved because the project was new and $\mathrm{C} 1$ could therefore see pleasure in creating routines for testing. However there was no time for writing these routines down and preserving for future test consultants.

\section{B.3.2.3 Summary of C2 interview}

$\mathrm{C} 2$ has been with Cybercom for three months and went from working at hourly basis during thesis work (7 months) to full-time employment three months before the interview. $\mathrm{C} 2$ has a university degree of MSc and has taken some programming courses in java. C2 also studied a course in user interfaces which C2 considered valuable for working at Cybercom. No prior work experience in the Software engineering domain except for development in thesis work. C2 has been involved in Project P1 during this time. Regarding education $\mathrm{C} 2$ would like to gain deeper understanding of one of the main technology behind Project P1. C2 was not the first consultant in Project P1 and the learning process started with overview introduction by PM and gradually advancing through parts of Project P1. Asked different consultants in the team when having questions $(70 \%$, documentation $30 \%)$. When reaching a certain level in Project P1 it became more difficult because the required use of hardware tools implied certain knowledge of the technology which was to be certified. $\mathrm{C} 2$ asked questions to the few consultants that had this deeper knowledge to solve those issues. C2 praised learning by personal knowledge transfer and also concluded that important parts of the documentation in Project P1 constitutes of various test and device specs that are static and created by the customer or certification authorities. This means that there is no guarantee that documentation is neither correct nor is it possible for Cybercom to require corrections to be made. The team has created a LazyDog of its own containing routines for testing. The learning process of $\mathrm{C} 2$ into Project P1 was 2 days for the first part of and a couple of weeks for the second part counting to a state where $\mathrm{C} 2$ felt self-propelled. C2 was happy with the learning process but think it could perhaps have been better if $\mathrm{C} 2$ had a dedicated mentor all the time instead of disturbing various people. 


\section{B.3.2.4 Analysis C2 interview}

One property that likely is unique for test consultancy companies is visible in the answers from $\mathrm{C} 2$, namely that consultancy companies do not necessarily have an influence in the quality of test documentation, because they do not own it. Even though testing in Project P1 is done completely in-house, test specifications, device specifications and even software tools are still received from a third party licensing authority abroad, meaning that test consultants have to depend on experience from within the team or from the customer development team in order to interpret specifications. This has likely contributed to the identified need to extend documentation with internal supplements, such as the LazyDog. Learning process of C2 depended heavily on communication with the Project P1 test team. In the beginning it was possible to ask anyone, but when reaching more advanced parts only few people had the required knowledge to help $\mathrm{C} 2$. A potential problem with asking a new team member for advice each time was identified by $\mathrm{C} 2$; that the person asked could potentially feel uneasy because no expressed responsibility for advising beginners existed in his or her work description. C2 could at first not identify any need of creativity for working with Project P1 with the motivation that most tests are prespecified. Instead motivation came from gaining deeper understanding of technologies behind Project P1, and of administrational issues such as editing the LazyDog.

\section{B.3.2.5 Summary of $\mathrm{C} 3$ interview}

With relatively long experience $\mathrm{C} 3$ has both relocated between projects and acquired responsibilities as team leader for the Project P1 team. While having a university degree of civil engineer as background further education of interest would be different management courses and test design. After working with Project P1 for a few months C3 started working with Project P2 in parallel. The learning process of C3 at Project P2 is described as learning-by-doing (test design) and mainly by communication with developers. The largest challenges was however participating in project meetings and learning development terminology. C3 was very positive about learning by communicating with developers but also admitted that documentation was insufficient and prevented test preparation. A suggested future improvement was to include flowcharts over system functionality. C3 thought working with Project P2 was motivating, mainly because $\mathrm{C} 3$ could influence many parts of development (such as user interfaces), but also because new areas appeared. Designing test cases gave use of creativity. When comparing Project P2 with Project P1 the access to documentation was larger in Project P1, even though learning was still associated with learning-bydoing in both projects. Experiences learned from working with different projects was both basic test philosophy and that frequent meetings contribute to creating and maintaining common goals in a team. The first work with Project P2 was the most motivating work with the two projects, because there was much to lay hands upon. The latter team responsibility of Project P1 has itself lead to that Project P1 work now is more motivating to work with.

\section{B.3.2.6 Analysis C3 interview}

Noticeable here is that project relocations are not always "sharp", in the sense of leaving an old project behind thus letting focus change completely to the new project. As C3 said, work with Project P2 mainly occurred close to releases. Even if not indicated by $\mathrm{C} 3$, there is a certain risk that such a situation could cause some consultants to not feel "at home" with the new project thus leading to extended learning processes. In the case of $\mathrm{C} 3$ learning did not occur in a coherent period of time, but instead occurred as bursts close to numerous incremental releases. Even though another Cybercom test consultant was present to provide test experiences, it 
seems like information needed were closer associated with technical development issues. C3 did not think of the learning process as being stressful, despite the fact that insufficient staffing prevented from testing everything needed. An example of problems that arose because of either the lack of a test plan or the documentation of it, was that $\mathrm{C} 3$ did not know how much time was available for testing thus ending up with too little time in the end. Another thing mentioned was that $\mathrm{C} 3$ was unofficially appointed customer contact person for the development team. One possible reason for this could have been that $\mathrm{C} 3$ during test work had acquired a better general knowledge of the system than the actual developers.

\section{B.3.2.7 Summary of C4 interview}

With 12 years experience from testing within Cybercom, C4 is the interviewee with the longest test experience from Cybercom. C4 has a university degree of civil engineer and has taken programming courses. Experience in TestCenter is 7 months in Project P1 and was before TestCenter preceded by work with automated testing in another part of the Cybercom group. C4 also had some programming experience. Although project relocation did not take place within TestCenter, relocation questions were still asked to broaden the study with some comparison between learning automated and non-automated testing projects. C4 started working with part 1 of Project P1 and learning process consisted much $(90 \%)$ of learning-by-asking thus people explained and showed practically how things were done, and 10\% time was spent by studying documentation. The biggest challenge with learning Project P1 testing was that contact with developers was lost. Part 1 of Project P1 was learned "immediately" but Part 2 was still at interview date an ongoing learning process according to C4. The introduction process of Project P1 is fairly good, due to that the process has a certain maturity. Having good documentation is more important when testing in Part 2 of Project P1 than in Part 1. C4 has had no contact with the customer during Project P1. Nor has there been any education connected to this project, only a short overview presentation was held. C4 thinks technical courses held by experts with the customer could be useful for this project. Judging by responses about documentation quality in Project P1 the weakest link is that documentation parts are not gathered sufficiently. Specific for the Project P1 LazyDog is that it works well and that everyone can contribute by filling in "tips and tricks", which C4 thinks is good. A possible way to improve the LazyDog could be to include motivations for test cases. This has to do with a special mentality of Project P1 that can be hard to understand - a mentality which means accepting that if the same test case fails twenty times but passes the twenty-first, this is sufficient for a test case pass. Working with Project P1 is more motivating than working with automated testing because "you can see what you do", however C4 does not think creativity is necessary when working with Project P1. When comparing Project P1 to automated testing experiences, learning within automated testing was much more structured including having advisor, and that it was specified what C4 should learn. Learning Project P1 was different in that everyone was supposed to know everything. Experiences learned during automated testing that were applicable to Project P1 testing was basic test thinking, knowledge of the physical devices involved, and the ability to communicate with people.

\section{B.3.2.8 Analysis C4 interview}

This interview broadened the knowledge of how Project P1 testing is experienced in practice. What mainly separates it from traditional test projects is that tests should receive a pass and if they do not, most likely the test method needs to be tweeked. However, occasionally the exact same test method fails numerous times and then spontaneously succeeds. This is in practice caused by a technical difficulty of measuring particular electronical behavior in the devices, resulting in somewhat 
unstable test tools (all of which are provided from third party). Even if explained this way and though basic factors in Project P1 testing are known to test consultants (i.e. what should be tested, with what tools and what results are acceptable), the lack of understanding of what is actually happening can obviously be a frustration factor. It is possible that the link to developers could be helpful in such understanding; however $\mathrm{C} 4$ felt that this link had become limited compared to when working with automated testing. Learning in Project P1 was described as unstructured question-asking to team members compared to structured learning in automated testing, but an interesting difference was also identified. Compared to the rigorous, formal and correct documentation in automated testing, the LazyDog in Project P1 was easy to read and free for everyone to edit. This gave a possibility for the team to tailor it to fit their learning needs. The gathered experiences in the LazyDog could likely act as counterweight to the lack of deep-technical understanding described earlier, by attacking the unknown with arguments from several different experience perspectives. Naturally there are also drawbacks with such documentation. Main examples are increased risk of inconsistent and of duplicate information.

\section{B.3.2.9 Summary of C5 interview}

C5 is the newest employee in the team and has worked with Project P1 for 1,5 months as seasonal job. While studying the last year for a civil engineer degree in physics at university software testing is "not C5's area". C5 thinks that technical education could be valuable to testers in general. The learning process started with the appointment of a mentor, and continued by running old tests in part 1 of Project P1. Later the same day sharp tests were run and in a week C5 was testing in part 2. During the first week a mentor was used for learning purposes and no documentation was studied (except for test specifications). After the first week C5 discovered the LazyDog and found it useable enough to replace most of the need for a mentor. A challenge identified by $\mathrm{C} 5$ was a difficulty to find project information. Despite this C5 thinks the introduction part of the project was optimal. If studying answers about perceived documentation quality, it seems that both documentation coverage and correctness was sufficient but not excellent, while it was both easy to read and to locate. Potential ways of improving it would be by using graphical illustrations and bulleted text because it is easier to read than a long text. C5 has had no contact with the customer during his time with Cybercom. A problem noticed with the procedure of asking through appointed contact persons was that it takes time before answers are received. The spontaneous answer about further education for Project P1 purposes was that there was no need, however C5 later acknowledged that it could be feasible for more advanced issues in part 2, education could make the interpretation of reference logs unnecessary. Motivation comes when something has been tried several times and finally succeeds by having some luck. Trying the same thing several times feels hard and like there is no contribution with something new. Some motivation comes from switching between part 1 and part 2 however Project P1 work is quite one-sided and gives little room for creativity. If creativity is needed it is in part 2 because documentation there is insufficient. $\mathrm{C} 5$ thinks that documentation perhaps can become too "good", which would make work boring.

\section{B.3.2.10 Analysis C5 interview}

Being new to Cybercom, C5 could give fresh experiences from the current learning process of Project P1. At this point in time dedicated mentorship had become an official way of learning newcomers in this project, which is embraced by $\mathrm{C} 5$. The decreased need of a mentor after discovering the LazyDog indicates that this documentation works well with answering initial questions about Project P1 during the first weeks in Project P1. As described by C5, documentation becomes more 
insufficient in part 2 of Project P1, which might result in a renewed dependency of the mentor. The overall need for more general project information could be based in that existing documentation is narrow, only covering step-by-step instructions and that it does not put the project in a larger context that could result in larger understanding. It is possible that the degree of understanding of the context of a project can affect the acceptance of doing one-sided work [12]. Also identified in this interview was that lack of technical knowledge seems to force the team to study reference logs in order to distinguish an erroneous behaviour from a correct.

\section{B.3.2.11 Summary of C6 interview}

C6 has a relatively long experience from Cybercom testing and has worked with Project P1 since 2006. Only a few weeks prior to interview C6 was relocated to the Project P3 which resulted in relatively new relocation experiences. C6 has studied programming and computer science courses at university level. Some work experience prior to Cybercom exists as well, both with user interface design and Visual Basic development. An interest to learn more about quality management, requirements engineering and security testing was visible. Since C6 started working with Project P3 in July 2007 the interview was conducted in two parts, the latter conducted 7 August to allow for a more extensive relocation experience to mature. Relocation was in large described as feeling very motivating, mostly because there was much to learn about the new system. In Project P1, testing was limited to a very small area that prevented an overall view of the system. An obstacle for learning to test in Project P3 was that relocation happened suddenly and in addition that only one day was given together with the one Cybercom consultant that was already in the project. For a week C6 had to learn everything on C6's own. During this time it was a bit hard to interact with the customer employees and C6 describes a feeling of not being socially accepted. According to $\mathrm{C} 6$ it seemed like the customer at first was not fully aware that C6 should take over after the other consultant, and that this could have caused confusion in the development team. When the other consultant returned, learning became easier and C6 explained during the second interview that C6 now felt fully accepted by the customer and that they had a good relation. $\mathrm{C} 6$ thought it was a big advantage sitting with the developers both because they knew the system and that it gave C6 influence in development. Another challenge with relocation was that C6 possessed deep knowledge of Project P1 which disappeared from the Project P1 team when C6 left. This meant that C6 during the learning process of Project P3 at a few occasions had to return to the Project P1 team in order to answer questions.

\section{B.3.2.12 Analysis C6 interview}

A classic problem with project relocations is from a knowledge management perspective, that project members possess experiences and knowledge that, if they have not been communicated, disappear from the project for good. The problem has remained unsolved, mostly because codification of knowledge is a difficult process. Especially troublesome is coding tacit knowledge, which is also called "silent knowledge" or the ability to successfully act without thinking [31]. This interview showed a real-world situation where this problem prevented a consultant to fully focus on a newly assigned project. Another challenge of relocation was visible from the interview, in the form of not having time to prepare for an upcoming relocation. A third obstacle was that C6 did not feel accepted in the customer development team at first and that this prevented C6 from having good communication with developers in order to help the learning process. Whether this was caused by a failure to communicate the purpose with C6's involvement can not be determined, but it is likely that such communication is important. There were indications that the project relocation in general was a positive experience for $\mathrm{C} 6$ and that the new project felt 
considerably more motivating and creative than the old. Main factors that contributed were; increased participation, increased influence and that testing was done on actual software. Clearly, focus in Project P1 was to find methods to produce acceptable test logs for a small component, which in this case prevented the perception that testing was done for the sake of software.

\section{B.3.2.13 Summary of C7 interview}

The interviewee had been working with Cybercom testing for 6 months with two projects, Project P4 and Project P3. At university C7 has taken a civil engineering education with computer science as major, in which several programming courses were included. During this education C7 has worked in several authentic software development projects. Desired future education would involve test management, parts of ISEB courses and management courses in general. When C7 joined Project P3 there was another Cybercom test consultant who passed the project over to C7. The introduction process included a quick overview introduction and also demonstration of a part of the system. C7 thinks this introduction was much too small. A positive thing was that the first consultant had made a folder with document links. C7 also had a mentor at the customer. A problem with having a long learning process is that the customer wants a hired consultant to "produce output" and not to study documentation. The largest challenge was to understand the hardware technology behind the devices that software was imbedded in. A requirement specification existed, but was insufficient, and a large portion of the learning process of $\mathrm{C} 7$ involved asking people (customer developers). Another challenge was that the test leader could not provide nessessary information. $\mathrm{C} 7$ thinks it would be a good idea if Cybercom had a documentation of its own for this project. It also took energy in the beginning to become accepted socially by the customer. During the second release communication became less important and improved documentation had a bigger role in learning. All in all it took three weeks until C7 felt self-propelled. C7 identified the importance of having a requirement specification, which was missing at first. To further improve the learning process $\mathrm{C} 7$ thinks a draft overview of software architecture would be valuable to create confidence. In addition it would be advantageous if knowledge that was transferred verbally could be written. $\mathrm{C} 7$ was allowed to attend a test design course from own initiative and a python course from customer initiative. There was no direct need of having even further education for this project, but possibly in performance or load testing, or in web applications. C7 felt the project was motivating but that source of motivation had changed from that of doing test design to learning the different parts of the system. The work was also creative in that $\mathrm{C} 7$ had to track errors to their roots. Compared to Project P4, which was an in-house project, Project P3 was much more motivating, mostly because the system was larger and there was more to learn. Customer interaction also posed a challenge not to step on someone's toes.

\section{B.3.2.14 Analysis C7 interview}

Having education and experience in areas of software engineering $\mathrm{C} 7$ identified several ways to improve the learning process during project relocation. The customer seemed to have a negative attitude towards paying consultants to study documentation, and instead preferred "direct output". This could present an important challenge that is unique for consultancy testing. If hiring of consultants is done unplanned to solve a temporary resource shortage, the customer value of consultants that produce visible output can be higher than that of consultants learning for long-term use. This creates a motivation for consultancy companies to evaluate the purpose of each customer closely in advance. Possibly such information could have an influence in forming more optimal learning processes in advance. 


\section{B.3.2.15 Summary of C8 interview}

Consultant C8 had approximately two months experience from working with Cybercom testing. During this time C8 has been involved in Project P2. Background of C8 involves university degree of civil engineering with some java programming courses included, and thesis work involving object-oriented development. C8 thinks further education in test design could be valuable, with the motivation that further theoretical test knowledge would help $\mathrm{C} 8$ have a more critical look on practical testing. C8 described that lack of such knowledge forced $\mathrm{C} 8$ to watch how others work and learn from them. There were several other test consultants from Cybercom in Project P2 when C8 started, and C8 describes a structured learning process in which C8 had an individual learning plan. Systematically trying different tools used in testing, C8 sat next to another consultant and could ask questions. After tools had been learned creation of test cases started, mostly by using old test cases to learn. Sharp testing was done a week later and at the same time C8 was introduced to the developers (located at another site). A user guide existed and C8 thinks that project contents were well-documented. The largest challenge with this project was that the time between starting to learn the test tools and sharp testing was short, and also that it was hard to know what should be tested. Nothing felt stressing, instead C8 considered it fun to work "for real" as compared to studying in academia. Rumours about testing being boring were dismissed quickly. The motivating part was designing test cases and that a close relationship with developers existed. Personal communication was an important part of the learning process $30 \%$, "clicking around" on C8's own as well $50 \%$, and documentation played a small part of $20 \%$. The personal connection lead to much faster learning than through documentation. In addition C8 thought documentation alone does not give connection to reality and that there is a need to see the "real thing" to understand. All in all it took about three weeks to become selfpropelled. C8 was happy with the introduction part of the project, especially that there was a learning plan, but also that information about tools, project goal and test deliverables was given. A drawback was that learning was a bit hectic. In large a thing that could have improved Project P2 test work would be if test consultants had participated in some of the daily developer meetings.

\section{B.3.2.16 Analysis C8 interview}

C8 describes a structured process of learning Project P2, involving an explicit learning plan, something that has not been described by other consultants. C8 identifies a clear purpose with acquiring test specific education, that it would enable C8 to have an informed and critical look on the overall test process. This could indicate that it is to current date not fully required by Cybercom test consultants to analyze test contents with critical eyes. In the case of test case creation this problem can manifest in the reuse of test cases. Instead of building test cases from own interpretations of requirements, a consultant could sometimes copy the contents of old test cases and only adjust them if necessary. Providing that such exist, study of old test cases can indeed contribute to the learning process by pinpointing software functionality thus contributing to overall system understanding, as in the case of C8. A drawback is that initial test cases might be based on erroneous requirement interpretations, thus resulting in that problems could be passed on between consultants. It is likely that learning the system by studying requirements would be a better alternative, not only in the sense that each consultant could contribute with individual interpretations and perspectives, but also that incorrect interpretations could be identified easier. 


\section{B.3.3 Summary of questions with quantitative answers}

Table B. 1. Summarized answers for quantitative questions

\begin{tabular}{|l|l|l|}
\hline ID & Question & $\begin{array}{l}\text { Mean value for answers ( 1 } \\
=\text { disagree, 5 agree } \\
\text { completely) }\end{array}$ \\
\hline 15 & $\begin{array}{l}\text { How well did you know the software development } \\
\text { model in the project before you begun? }\end{array}$ & 1.0 \\
\hline 18 & $\begin{array}{l}\text { The different parts of test documentation are } \\
\text { gathered in one place? }\end{array}$ & 3.0 \\
\hline 19 & $\begin{array}{l}\text { The coverage of existing test documentation was } \\
\text { sufficient enough for my needs }\end{array}$ & 3.2 \\
\hline 20 & $\begin{array}{l}\text { The information in existing test documentation } \\
\text { was constantly updated and correct }\end{array}$ & 3.2 \\
\hline 21 & $\begin{array}{l}\text { The contents of existing test documentation was } \\
\text { easy to understand }\end{array}$ & 3.8 \\
\hline 29 & $\begin{array}{l}\text { The test documentation has a similar structure in } \\
\text { both projects, that helped me know where to look } \\
\text { for information }\end{array}$ & 1.2 \\
\hline 31 & $\begin{array}{l}\text { I had enough time for preparation before } \\
\text { relocation occurred }\end{array}$ & 2.3 \\
\hline
\end{tabular}

It should be clarified here that Question 18 concerned documentation within singular projects. This means that documentation were, in mean, moderately gathered for each project. With the result from Question 29 we see that there is still a large variation in documentation appearance between the projects, which means documentation experience from previous projects could not be helpful in others. Further conclusions from the quantitative questions have been included in the following sections.

\section{B.3.4 Gathered experiences - strong tendencies}

This table lists a number of tendencies that are supported by a majority of interviewee answers. These have been called strong because no experiences have challenged them.

Table B. 2. Experience tendencies

\begin{tabular}{|c|c|c|}
\hline AREA & TENDENCY & REFLECTION \\
\hline $\begin{array}{l}\text { Consultant } \\
\text { backgrounds }\end{array}$ & $\begin{array}{l}\text { Consultants have very uniform } \\
\text { educational backgrounds. } \\
\text { - All consultants have or are } \\
\text { acquiring a civil engineering } \\
\text { degree corresponding to } 4,5 \\
\text { years of university studies. } \\
\text { - All consultants have taken } \\
\text { some programming courses. } \\
\text { - Nobody has studied any course } \\
\text { concerned with software testing } \\
\text { before Cybercom employment. } \\
\text { - All thought a test course called } \\
\text { ISEB seemed useful, however } \\
\text { only a few have studied it. }\end{array}$ & $\begin{array}{l}\text { - Further education in the specific area } \\
\text { of software verification and validation } \\
\text { could improve understanding of the } \\
\text { field of work. Familiarity with } \\
\text { studying techniques gives consultants } \\
\text { good prospects of succeeding such } \\
\text { education. } \\
\text { - Company has suggested the test course } \\
\text { ISEB and provided material for self- } \\
\text { study with bonus award upon } \\
\text { certification. Possibly a supervised } \\
\text { course class with teacher could be an } \\
\text { alternative and achieved certifications } \\
\text { could be a sales argument towards } \\
\text { customers. } \\
\text { There can be at least two drawbacks } \\
\text { with employing test consultants with } \\
\text { very similar educational background; }\end{array}$ \\
\hline
\end{tabular}




\begin{tabular}{|c|c|c|}
\hline & & $\begin{array}{l}\text { 1. It might not encourage } \\
\text { different perspectives of a } \\
\text { situation. } \\
\text { 2. Employing only consultants } \\
\text { specialized in technical } \\
\text { engineering might create a } \\
\text { lack of competence in non- } \\
\text { technical areas of testing, such } \\
\text { as understanding usability. }\end{array}$ \\
\hline & $\begin{array}{l}\text { Almost no formal education has been } \\
\text { given before or during a project for the } \\
\text { sake of that project. }\end{array}$ & $\begin{array}{l}\text { There might be a lack of available courses that } \\
\text { are specialized in the test areas involved. There } \\
\text { is also an economical aspect to consider } \\
\text { depending on factors like the length of projects } \\
\text { and the reusability of courses in later projects. }\end{array}$ \\
\hline \multirow[t]{2}{*}{ Misc } & $\begin{array}{l}\text { Main tasks in test work with TestCenter } \\
\text { seem to have been test design and test } \\
\text { execution. }\end{array}$ & $\begin{array}{l}\text { Even though consultants occasionally have had } \\
\text { responsibility for testing "test leader" it seems } \\
\text { to be test design and execution that most } \\
\text { consultants think of when they refer to work at } \\
\text { TestCenter. } \\
\text { For the current being competence focused on } \\
\text { test case design and test execution seems } \\
\text { important. However, for large test projects } \\
\text { more knowledge about test planning could be } \\
\text { feasible. }\end{array}$ \\
\hline & $\begin{array}{l}\text { Motivation in work with Project P1 } \\
\text { seems to come from adjusting the } \\
\text { methods used and learning about the } \\
\text { technology }\end{array}$ & $\begin{array}{l}\text { Creativity is not needed to execute pre- } \\
\text { specified test cases, but can be used in a } \\
\text { process improvement context instead, thus still } \\
\text { creating a degree of work motivation. It could } \\
\text { be feasible to develop an automated test } \\
\text { solution to support the future of this project. }\end{array}$ \\
\hline \multirow[t]{3}{*}{$\begin{array}{l}\text { Learning } \\
\text { projects }\end{array}$} & $\begin{array}{l}\text { Learning by asking others is } \\
\text { unanimously the preferred method of } \\
\text { learning new test projects. }\end{array}$ & $\begin{array}{l}\text { Reliance on verbal communication with others } \\
\text { can be effective for learning purposes but can } \\
\text { be expensive if the same question is asked by } \\
\text { many different consultants or to the wrong } \\
\text { persons. }\end{array}$ \\
\hline & $\begin{array}{l}\text { Problems with insufficient requirement } \\
\text { representations have been a large issue. } \\
\text { Different graphical representations have } \\
\text { been suggested by several. }\end{array}$ & See A.5.2.1. \\
\hline & $\begin{array}{l}\text { The Project P1 LazyDog has been } \\
\text { praised by all with regards to useful } \\
\text { documentation }\end{array}$ & $\begin{array}{l}\text { The LazyDog consists of step-by-step } \\
\text { instructions for each test case, along with tips } \\
\text { and tricks to make tests pass. It was created } \\
\text { and is maintained by TestCenter consultants. }\end{array}$ \\
\hline $\begin{array}{l}\text { Project } \\
\text { relocation }\end{array}$ & $\begin{array}{l}\text { All that have been relocated have } \\
\text { mainly positive experiences about } \\
\text { project relocations. Although challenges } \\
\text { and difficulties have been identified, } \\
\text { nobody has experienced the relocation } \\
\text { as being stressful. }\end{array}$ & $\begin{array}{l}\text { This is positive with regards to striving for } \\
\text { high staff mobility as desired by the } \\
\text { TestCenter Model. There are however factors } \\
\text { outside of project relocations that could have } \\
\text { biased consultant experiences from relocations } \\
\text { in a positive way. }\end{array}$ \\
\hline
\end{tabular}

Perhaps the most unpredicted of these tendencies is the last one presented. The main concern from a management perspective was to introduce support to having more 
frequent project staff relocations. Previous relocations were believed, at least before the interviews, to have caused stress that to some extent decreased overall work motivation in the new projects. Even though it was possible to identify challenges (Table B. 3) with consultant relocations, these do not seem to have had any significant negative effect on overall project work motivation. On the contrary, motivation seems to have increased with previous relocations. There are a few factors that should be considered in this context;

- Many consultants considered thirst of exploring new things the main power source in relocations. It is uncertain if this thirst is affected after numerous relocations. None of the interviewees has been relocated more than twice.

- Most have less work experience than a year. Motivation can be effected by factors like job satisfaction, which has been found to have correlations with age [36].

- Most relocations occurred from a project considered by many to offer only a small amount of creativity and motivation (Project P1).

This gives an indication that there is room for additional research on this topic. Preferably, future research could be conducted from both qualitative and quantitative aspects with purpose of finding if (and how) the number of performed relocations and other factors (such as experience and variety in projects) affect individual motivation in consultancy companies. For now we have to settle with the most logical conclusion we can make from the available results; that suitable support to the challenges identified is one of the ways to improve consultant relocations.

\section{B.3.5 Challenges identified}

Depending on the context from the interviews, challenges have been divided into three categories; General challenges, Project Learning challenges and Relocation challenges. General challenges are those that are not project-specific, project learning challenges are associated with learning to work in specific projects and relocation challenges are those associated with other aspects of project relocations.

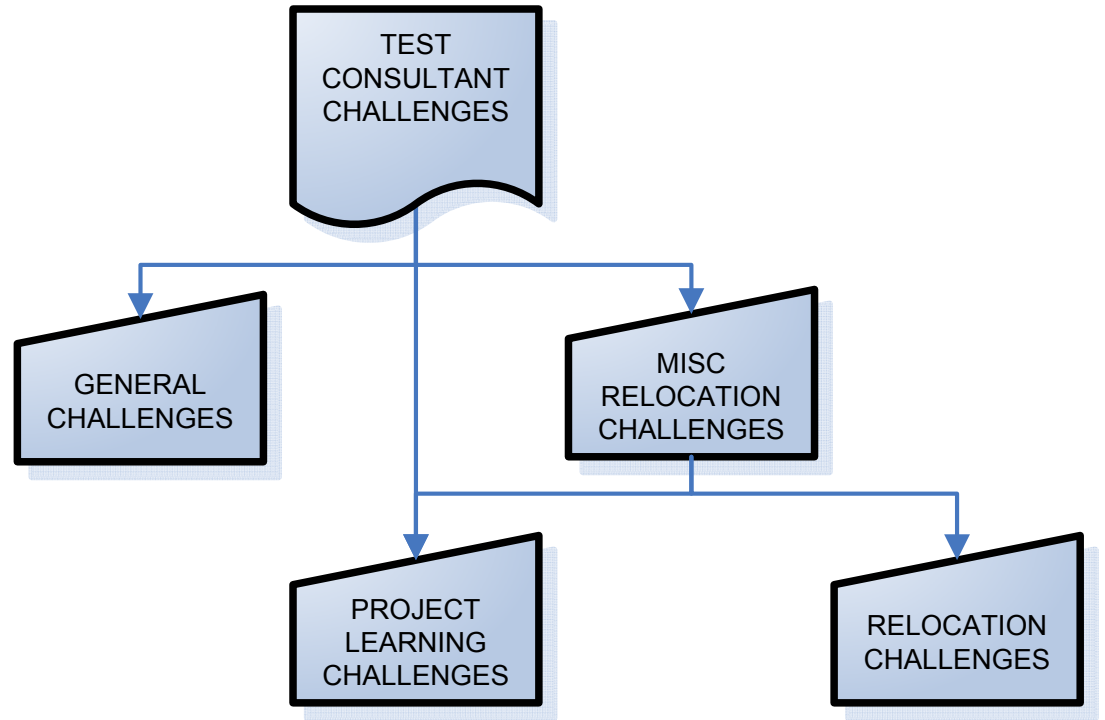

Figure B. 1. Challenge categories

In Table B. 3 all identified challenges have been listed. Besides of description, interview source and challenge categories (as in Figure B. 1) there is a division into abstract areas. Furthermore it would be feasible to see if any of the variable properties derived from project descriptions (B.2.1.2) actually cause project learning challenges; especially since they in general were believed to be more common in consultancy contexts than in traditional 
development testing. The column with relations shows which of these properties that seem to cause or contribute to the existence of each associated challenge.

Table B. 3. Experienced challenges

\begin{tabular}{|c|c|c|c|c|}
\hline Abstract area & Challenge description & Source & $\begin{array}{l}\text { Related to } \\
\text { test project } \\
\text { property } \\
\text { (B.2) }\end{array}$ & $\begin{array}{l}\text { Expressed in } \\
\text { context / Type of } \\
\text { challenge } \\
\text { (General/ Project } \\
\text { Learning } \\
\text { Relocation) } \\
\end{array}$ \\
\hline Communication & Knowing who to ask & $\mathrm{C} 1$ & & Project Learning \\
\hline Communication & $\begin{array}{l}\text { Not to disturb others more than } \\
\text { necessary }\end{array}$ & $\mathrm{C} 1, \mathrm{C} 2$ & & Project Learning \\
\hline Communication & $\begin{array}{l}\text { Late answers because of } \\
\text { communication only through } \\
\text { dedicated contact persons }\end{array}$ & $\mathrm{C} 5$ & & General \\
\hline Competence & $\begin{array}{l}\text { Test case creation based on } \\
\text { system knowledge and technical } \\
\text { competence (instead of } \\
\text { extending old cases) }\end{array}$ & $\mathrm{C} 5, \mathrm{C} 8$ & & General \\
\hline Competence & $\begin{array}{l}\text { Learning existing customer } \\
\text { product (software+hardware) }\end{array}$ & $\mathrm{C} 6, \mathrm{C} 7$ & Prop4 & Project Learning \\
\hline $\begin{array}{l}\text { Customer } \\
\text { relation }\end{array}$ & Learning customer terminology & $\mathrm{C} 3$ & Prop9 & Project Learning \\
\hline $\begin{array}{l}\text { Customer } \\
\text { relation }\end{array}$ & $\begin{array}{l}\text { Becoming socially accepted at } \\
\text { customer site }\end{array}$ & $\mathrm{C} 6, \mathrm{C} 7$ & Prop10 & Relocation \\
\hline $\begin{array}{l}\text { Customer } \\
\text { relation }\end{array}$ & $\begin{array}{l}\text { Customer discouraged study of } \\
\text { documentation because } \\
\text { customer did not consider it } \\
\text { productive }\end{array}$ & C7 & Prop10 & Project Learning \\
\hline $\begin{array}{l}\text { Customer } \\
\text { relation }\end{array}$ & $\begin{array}{l}\text { Avoid stepping on someone's } \\
\text { toes }\end{array}$ & C7 & Prop10 & Project Learning \\
\hline Documentation & $\begin{array}{l}\text { Insufficient } \\
\text { specifications } \\
\text { illustrated) }\end{array}$ & $\begin{array}{l}\mathrm{C} 1 \\
\mathrm{C} 4 \\
\mathrm{C} 5, \mathrm{C} 7 \\
\end{array}$ & $\begin{array}{l}\text { Prop3, } \\
\text { Prop12 }\end{array}$ & General \\
\hline Documentation & $\begin{array}{l}\text { Limited influence in project } \\
\text { documentation when consulting }\end{array}$ & $\mathrm{C} 2$ & Prop12 & General \\
\hline Documentation & $\begin{array}{l}\text { Lack of test plan }- \text { resource } \\
\text { planning failure }\end{array}$ & $\mathrm{C} 3$ & & General \\
\hline Documentation & $\begin{array}{l}\begin{array}{l}\text { Knowing where } \\
\text { information }\end{array} \\
\text { to find } \\
\end{array}$ & $\mathrm{C} 5$ & & Project Learning \\
\hline $\begin{array}{l}\text { Interfering } \\
\text { activity }\end{array}$ & $\begin{array}{l}\text { Distraction from learning new } \\
\text { project because receiving } \\
\text { questions about an old project. }\end{array}$ & C6 & & Relocation \\
\hline Test purpose & $\begin{array}{l}\text { Purpose of Project P1 individual } \\
\text { test cases hard to understand }\end{array}$ & $\mathrm{C} 3$ & Prop5 & General \\
\hline $\begin{array}{ll}\text { Time } & \text { related } \\
\text { issue } & \\
\end{array}$ & $\begin{array}{l}\text { Insufficient time for preparation } \\
\text { prior to relocation }\end{array}$ & $\begin{array}{l}\mathrm{C} 1, \\
\mathrm{C} 6, \mathrm{C} 8\end{array}$ & Prop13 & Project Learning \\
\hline $\begin{array}{l}\text { Time } \\
\text { issue }\end{array}$ & $\begin{array}{l}\text { Not enough time to write } \\
\text { routines down during project }\end{array}$ & $\mathrm{C} 1$ & & General \\
\hline
\end{tabular}




\section{B.3.6 Challenges discussion}

As can be seen in Table B. 3, challenges identified in this study have a limited correlation to the project properties described earlier (B.2.2). Approximately a third of the project properties identified have an obvious connection to the challenges experienced by consultants, and half of the challenges are not directly connected to an identified property. Instead challenges associated with both general test work and relocations between test projects seem to depend on more general external factors. Challenges of communication, poor documentation, insufficient time for relocation preparation and interference from other projects are all examples of obstacles that could appear in the learning processes of most test projects, regardless of project characteristics. Since many of the properties identified earlier were believed to pose unique challenges for the consultancy domain, this result implies that challenges identified in this study might be generalizable into the whole software testing domain as well, and not only for consultancy testing. It should be noticed that the challenges presented should not be placed on an equal footing with problems to consultants, but possibly with the efficiency of project learning processes. Instead of causing stressful situations several of the challenges have actually increased the work motivation for the interviewed test consultants. 


\section{B.4 SURVEY RESULTS}

\section{B.4.1 LSI test results}

The original scoring table was used to calculate results.

Table B. 4. LSI scoring table, from [14] (values of bold words were summarized for each column)

\begin{tabular}{|l|l|l|l|}
\hline CE & RO & AC & AE \\
\hline \hline Discriminating & Tentative & Involved & Practical \\
\hline Receptive & Relevant & Analytical & Impartial \\
\hline Feeling & Watching & Thinking & Doing \\
\hline Accepting & Risk-taker & Evaluative & Aware \\
\hline Intuitive & Productive & Logical & Questioning \\
\hline Abstract & Observing & Concrete & Active \\
\hline Present-oriented & Reflecting & Future-Oriented & Pragmatic \\
\hline Experience & Observation & Conceptualization & Experimentation \\
\hline Intense & Reserved & Rational & Responsible \\
\hline
\end{tabular}

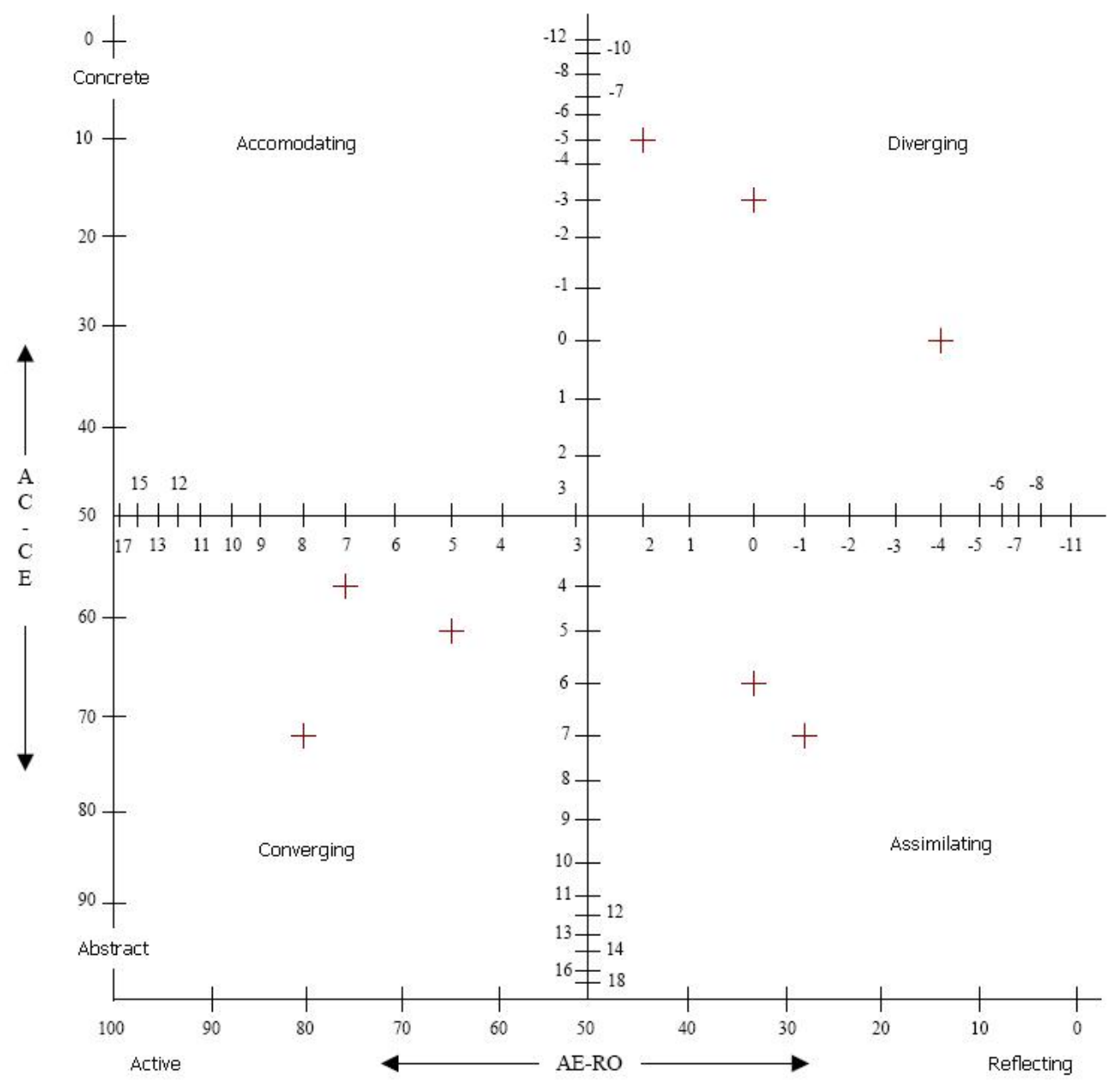

Figure B. 2. LSI test result diagram (diagram template from [14]. Red crosses mark respondents.) 


\section{B.4.2 LSI test results discussion}

By looking at the gathered result from the LSI test it is obvious that the consultants at TestCenter have very different approaches to learning. Five conclusions can be drawn from this;

- There is a minimal overweight towards the Reflecting side of the Active/Reflective axis. While likely not of any significance, it has been shown that academia staff is often positioned towards the Reflective side of this axis [14]. One possible explanation could be that TestCenter consultants have experience from reflective analysis in academia.

- A majority of the test consultants were expected to gather on the Concrete side of the Abstract/Concrete scale. This was because previous interviews showed that the respondents in general preferred to learn by communicating with others rather than from documentation. Learning by communication is associated with the Concrete half of Kolb's diagram, but in the LSI test result, a small majority was on the Abstract side.

- There is an indication that the very uniform education backgrounds of TestCenter consultants have not influenced how they prefer to acquire new knowledge.

- Human beings adjust, or in extreme cases even switches, its learning style to better fit their environments [14]. The LSI results from this study do however not indicate that software testers move towards a certain learning style position in the diagram.

- No consultant is present in the Accommodating quadrant. If a perfectly random population was measured it would be evenly distributed among the quadrants in the diagram, in this case with two consultants in each, in mean. As mentioned earlier there are too few data points available to claim that this is a deviance, however it could be of interest to future research to investigate this in larger scale.

Accommodators are people that are risk takers; they study a phenomenon and then experiment to gain new knowledge; "What happens if I change this?" [14]. Such software testers could likely be of large value in test work, since they would not stick to functional descriptions when testing products. A specific test type that could therefore suit the Accomodator is explorative testing. An existence of such deviance could indicate that accommodators are not comfortable with present-day software testing practices and that these need to evolve to better suit this group. Parallels can be drawn with current research, which suggests that Accommodator is the second smallest learning style (13\%) amongst students in engineering educations [37].

\section{B.4.3 Personality test results}

As Buchanan means were presented separately for male and female categories, a merged mean was calculated for the Buchanan results, using known quantities of male and female respondents from the Buchanan result presentation [26]. Mean values from the different IPIP tests are displayed below, along with a bar diagram to graphically display the results. 
Table B. 5. Mean values from IPIP test results

\begin{tabular}{lrrr} 
Big-five Category & \multicolumn{1}{c}{$\begin{array}{l}\text { Buchanan } \\
\text { mean }\end{array}$} & $\begin{array}{l}\text { Feldt } \\
\text { mean }\end{array}$ & \multicolumn{1}{l}{$\begin{array}{l}\text { Daniel } \\
\text { mean }\end{array}$} \\
Extraversion & 25,52 & 33,47 & 39,13 \\
Agreeableness & 32,53 & 38,43 & 41,38 \\
Conscientiousness & 28,21 & 36,30 & 39,25 \\
Emotional Stability & 25,23 & 37,09 & 40,13 \\
Intellect/Openness & 21,57 & 37,53 & 38,50
\end{tabular}

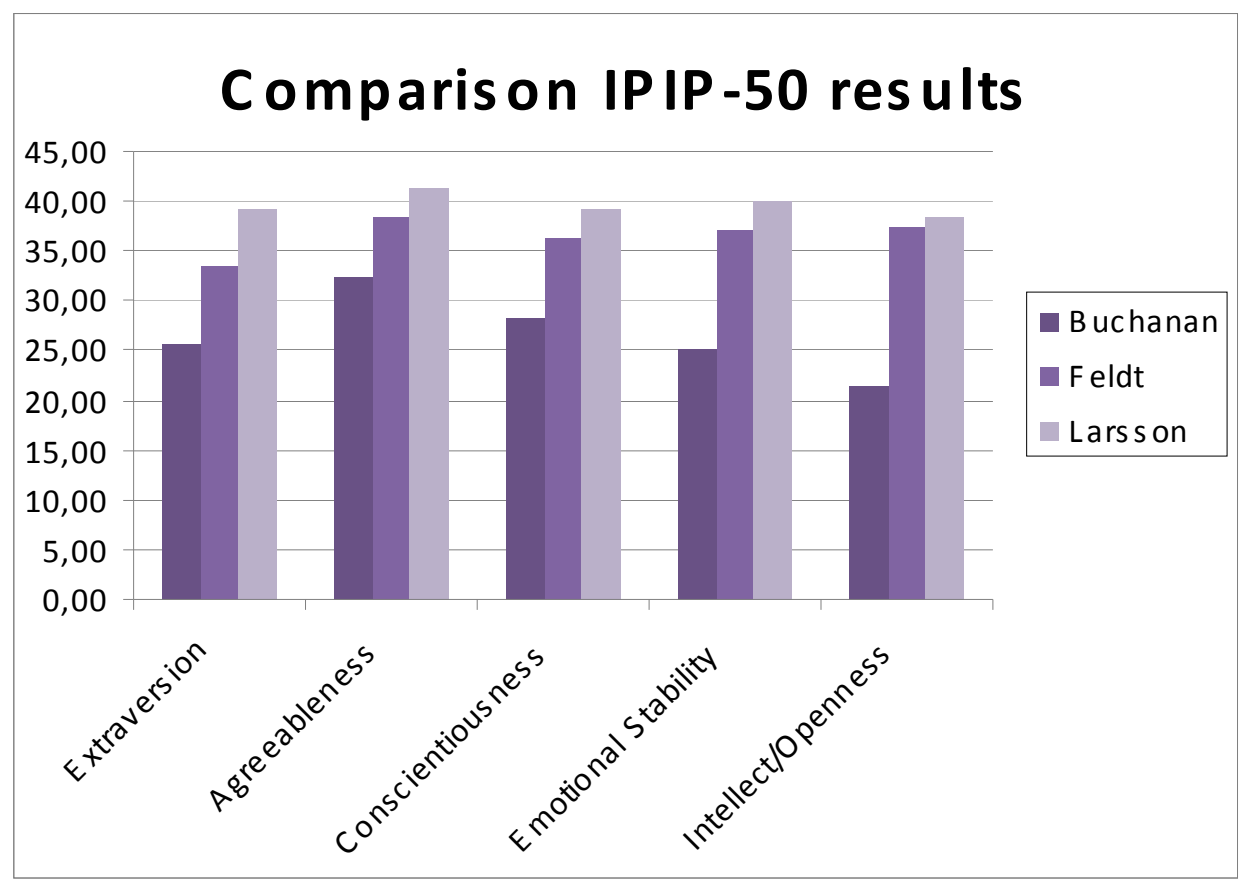

Figure B. 3. IPIP test results bar diagram

\section{B.4.4 Personality test results discussion}

The small number of respondents makes complex statistical calculations unfeasible. Nevertheless several observations can be made from Figure B. 3. There are strong similarities between Software Engineers (SE) and Test consultants (TC) (Feldt resp. Larsson), especially when compared to the masses (M) (Buchanan). This was expected since both test engineers and software engineers are technicians involved in the same main business; software development. For the Extraversion factor there is a significant difference between Feldt and this study. One possible explanation can be that the respondents in this thesis are consultants and need to be able to interact with customers on a daily basis, while the average software engineer does not. As can be seen in the interview results from TestCenter consultants, most embrace learning-by-asking as an efficient method of learning to work in new projects. This might correlate to the high extraversion levels indicated by these personality tests. When this result was showed to the project manager at TestCenter he explained that extraversion was actually a key factor when recruiting new consultants. It is likely that a mix of the working environment and recruitment philosophy has contributed to the high extraversion value presented. Furthermore, it is possible that specifically the high value for the fifth factor 
Intellect/Openness could have a positive influence in test consultant attitudes towards being open to new challenges thus embracing new projects for learning.

Overall SE and TC have significantly higher values than the broad masses, and less deviations between the factors. It should be noted however, that in both this study and in the Feldt study [16] respondents were professionals that answered the IPIP tests in corporative environments, often during work-time. IPIP tests are based on selfassessment and therefore a certain risk exists, namely that performance stress has biased these surveys. Since high values of all five personality factors often is requested by employers today, respondents might have answered the personality question items according to who they think the employer wants them to be. Depending on what trust respondents had for the LSI test manager regarding anonymity, some of the large differences to Buchanan results can possibly be explained this way. Since the dimension of this fault is not measurable it is unfeasible to use this study to claim that people working with software development have stronger personalities than others. 


\section{B.5 RESULTS FROM STATIC VALIDATION}

\section{B.5.1 Discussion of results from static validation}

During the static validation interview with the TestCenter project manager (PM), the PM was invited to ask questions about the improvements suggestions in case anything seemed unclear. PM did not have any questions and described the general outcomes of the suggestions to be very positive and that the situation was well interpreted by the author. Naturally it is an essential prerequisite that the creator of improvement suggestions has understood the problem area correctly, even though interview questions for static validation did not include that question. In addition the PM was positive about that suggestions were tangible and that it contained a template that could be used for evaluation in sharp environments. As described earlier time limitations during the thesis project implied that results from such evaluation would unfortunately not be possible to include in this study. The fact that the PM immediately decided to try the HotDog in a sharp environment gave however clear indications that the improvements suggestions seemed appropriate.

The General Concept section of the questions covered the appropriateness of the suggestions in general. Answers from PM indicated that the industrial goal of the study had been reached. The PM was convinced that it would be possible to decrease the learning time in new test projects for consultants by using the HotDog solution. From the company perspective this would imply that staff would become more mobile with regards to project staff relocations. The first two reasons expressed were;

1. It would be possible for the consultant to prepare before relocation

2. The documentation would give consultants a feeling of confidence

In the improvement suggestions report increased confidence was not thoroughly discussed as an advantage. The answer from PM could indicate that a more abstract challenge of project staff relocations can be confidence. Confidence has likely only small correlations with specific project properties, but instead builds on the mental aspect of relocations and should be addressed in future research.

In the improvement suggestions report it was believed that the HotDog could offer support to test consultants throughout test projects by including up-to-date information. The PM predicted however that its usage would probably be more focused to the consultant introduction periods of projects and less during the remainders. This was also visible in the answers for question 11, where PM stated that updates would likely not occur continuously. Instead it would be more suitable to make updates on a few occasions, like in the beginning and end of projects.

The questions that addressed the Test Experience Template usage gave positive predictions. The re-use of tacit knowledge had already been visible with the use of the LazyDog, even though it was in smaller context such as to know which document was the best to use in what situation. A risk with experience extraction this way is that experiences might get too widespread and could become difficult to gather. A possible solution to this was to create more subsections of test work information. The PM considered it too early to suggest examples of further sections at this stage and that the solution with Test Experience Templates needed to be tested in order to expose valuable experience subsections. 
While PM was certain of the cost efficiency of HotDog usage and that there in total were more advantages than disadvantages, two potential issues that needed to be discussed in the company before implementation were;

1. Maintenance of HotDog will use time resources. Either Cybercom or the customer would need to stand this economical cost. While some customers might accept the cost others may not see the gains as worth paying for.

2. Everyone does not enjoy writing documentation. This calls for rules to be created on how and what to update.

The handling of the first issue was stressed in the improvement suggestions report and was also acknowledged by the PM. It might for example be necessary for consultants to work overtime in some cases. A resource consultancy context could for example imply that the customer requires full forty hour participation per week. The second issue implies that the company would need to create some control of HotDog processes and contents in order to keep them updated. Even though consultant interest in writing documentation will naturally vary, PM did not think of this as a major obstacle but one that could be won by managerial control. 


\section{Appendix C - Interview Questions and Answers}




\section{C.1 INTERVIEW QUESTIONS}

Table C. 1. Interview questions with rationale and answer types

\begin{tabular}{|c|c|c|c|c|}
\hline SECTION & RATIONALE & $\begin{array}{l}\text { QUESTION } \\
\text { ID }\end{array}$ & QUESTION & $\begin{array}{l}\text { OUTCOME } \\
\text { FORMAT }\end{array}$ \\
\hline \multicolumn{5}{|l|}{ Common part } \\
\hline & Interview relevance & Q1 & $\begin{array}{l}\text { For how long time have you been } \\
\text { working with testing in Cybercom? }\end{array}$ & Months \\
\hline & Entry competence & Q2 & $\begin{array}{l}\text { Did you have any education or } \\
\text { experience within software testing } \\
\text { before you started at Cybercom? }\end{array}$ & Text \\
\hline & $\begin{array}{l}\text { Interview relevance } \\
\text { (exp. connection to } \\
\text { education desire) }\end{array}$ & Q3 & $\begin{array}{l}\text { Do you have any work experience } \\
\text { from other areas within software } \\
\text { development? }\end{array}$ & Text \\
\hline & $\begin{array}{l}\text { Guides remainder } \\
\text { of interview }\end{array}$ & Q4 & $\begin{array}{l}\text { Which test projects have you worked } \\
\text { in, and in what order? }\end{array}$ & Text \\
\hline & $\begin{array}{l}\text { Experienced lack in } \\
\text { competence }\end{array}$ & Q5 & $\begin{array}{l}\text { Is there any education area where you } \\
\text { would like to learn more to make you } \\
\text { an even better test consultant in } \\
\text { general? }\end{array}$ & Text \\
\hline & & & & \\
\hline \multirow[t]{8}{*}{$\begin{array}{l}\text { Project specific } \\
\text { part }\end{array}$} & $\begin{array}{l}\text { Validity/Relevance; } \\
\text { How much } \\
\text { information is likely } \\
\text { to have been } \\
\text { forgotten? }\end{array}$ & Q6 & $\begin{array}{l}\text { When did you start working in this } \\
\text { project? }\end{array}$ & Months \\
\hline & $\begin{array}{l}\text { Internal knowledge } \\
\text { transfer possible? }\end{array}$ & Q7 & $\begin{array}{l}\text { Were there Cybercom test consultants } \\
\text { in the project when you started? }\end{array}$ & $\begin{array}{l}\text { number and } \\
\text { names }\end{array}$ \\
\hline & $\begin{array}{l}\text { The actual learning } \\
\text { process }\end{array}$ & Q8 & $\begin{array}{l}\text { Can you tell me about how you } \\
\text { learned to work in the project? }\end{array}$ & Text \\
\hline & $\begin{array}{l}\text { What obstacles } \\
\text { needed to be } \\
\text { conquered? }\end{array}$ & Q9 & $\begin{array}{l}\text { What was the biggest challenge with } \\
\text { learning to work in this project? }\end{array}$ & Text \\
\hline & $\begin{array}{l}\text { What obstacles } \\
\text { needed to be } \\
\text { conquered? }\end{array}$ & Q10 & Was there anything that felt stressing? & Text \\
\hline & Knowledge transfer & Q11 & $\begin{array}{l}\text { How large practical importance did } \\
\text { you feel that learning with the use of } \\
\text { mentor or other person got in relation } \\
\text { to how much you could learn by } \\
\text { studying documentation? }\end{array}$ & $\begin{array}{l}\text { text }(\% \\
\text { preferred })\end{array}$ \\
\hline & $\begin{array}{l}\text { Efficiency of } \\
\text { relocation process }\end{array}$ & Q12 & $\begin{array}{l}\text { How long time did it take for you to } \\
\text { become self-propelled? }\end{array}$ & Text \\
\hline & $\begin{array}{l}\text { Room for } \\
\text { improvement }\end{array}$ & Q13 & $\begin{array}{l}\text { Was the introduction and learning part } \\
\text { of the project optimal? Do you think it } \\
\text { could be improved? }\end{array}$ & Text \\
\hline
\end{tabular}




\begin{tabular}{|c|c|c|c|c|}
\hline & $\begin{array}{l}\text { Customer } \\
\text { interaction }\end{array}$ & Q14 & $\begin{array}{l}\text { Did you have any contact with the } \\
\text { customer? Could you solve the } \\
\text { questions and issues that arose? }\end{array}$ & Text \\
\hline & $\begin{array}{l}\text { Pre-project } \\
\text { competence }\end{array}$ & Q15 & $\begin{array}{l}\text { How well did you know the software } \\
\text { development model in the project } \\
\text { before you begun? }\end{array}$ & \begin{tabular}{|l|}
$1-5$ \\
$(1=$ disagree, \\
$5=$ agree \\
completely \\
\end{tabular} \\
\hline & $\begin{array}{l}\text { Planned project- } \\
\text { specific education }\end{array}$ & Q16 & $\begin{array}{l}\text { Did you before or during the project } \\
\text { receive any kind of formal education, } \\
\text { including education at customer site? }\end{array}$ & Text \\
\hline & $\begin{array}{l}\text { Identify gaps in } \\
\text { current knowledge } \\
\text { transfer }\end{array}$ & Q17 & $\begin{array}{l}\text { Do you think you could have had use } \\
\text { of any further education for the sake of } \\
\text { this specific project? }\end{array}$ & Text \\
\hline & & & & \\
\hline & $\begin{array}{l}\text { Documentation } \\
\text { quality }\end{array}$ & Q18 & $\begin{array}{l}\text { (Statement) The different parts of test } \\
\text { documentation are gathered in one } \\
\text { place? }\end{array}$ & \begin{tabular}{|l|}
$1-5$ \\
$(1=$ disagree \\
$5=$ agree \\
completely \\
\end{tabular} \\
\hline & $\begin{array}{l}\text { Documentation } \\
\text { quality }\end{array}$ & Q19 & $\begin{array}{l}\text { (Statement) The coverage of existing } \\
\text { test documentation was sufficient } \\
\text { enough for my needs }\end{array}$ & $\begin{array}{l}1-5 \\
(1=\text { disagree }, \\
5=\text { agree } \\
\text { completely } \\
\end{array}$ \\
\hline & $\begin{array}{l}\text { Documentation } \\
\text { quality }\end{array}$ & Q20 & $\begin{array}{l}\text { (Statement) The information in existing } \\
\text { test documentation was constantly } \\
\text { updated and correct }\end{array}$ & $\begin{array}{l}1-5 \\
(1=\text { disagree }, \\
5=\text { agree } \\
\text { completely } \\
\end{array}$ \\
\hline & $\begin{array}{l}\text { Documentation } \\
\text { quality }\end{array}$ & Q21 & $\begin{array}{l}\text { (Statement) The contents of existing } \\
\text { test documentation was easy to } \\
\text { understand }\end{array}$ & \begin{tabular}{|l|}
$1-5$ \\
$(1=$ disagree \\
$5=$ agree \\
completely \\
\end{tabular} \\
\hline & $\begin{array}{l}\text { Documentation } \\
\text { quality }\end{array}$ & Q22 & $\begin{array}{l}\text { What type of information or } \\
\text { presentation would make it } \\
\text { (documentation) even better? }\end{array}$ & Text \\
\hline & $\begin{array}{l}\text { What creates } \\
\text { motivation? }\end{array}$ & Q23 & $\begin{array}{l}\text { What properties in working with this } \\
\text { project felt motivating? }\end{array}$ & Text \\
\hline & Creativity & Q24 & $\begin{array}{l}\text { Did the work demand any creativity to } \\
\text { be done? In what ways? }\end{array}$ & Text \\
\hline \multirow[t]{4}{*}{$\begin{array}{l}\text { Relocation } \\
\text { specific part }\end{array}$} & $\begin{array}{l}\text { Validity/Relevance; } \\
\text { How much } \\
\text { information is likely } \\
\text { to have been } \\
\text { forgotten? }\end{array}$ & Q25 & $\begin{array}{l}\text { When did you change project the last } \\
\text { time? }\end{array}$ & Month \\
\hline & $\begin{array}{l}\text { Was there a } \\
\text { natural interest to } \\
\text { relocate? }\end{array}$ & Q26 & $\begin{array}{l}\text { Who took the initiative for the } \\
\text { relocation? }\end{array}$ & Text \\
\hline & $\begin{array}{l}\text { Was there a } \\
\text { natural interest to } \\
\text { relocate? }\end{array}$ & Q27 & $\begin{array}{l}\text { Did you look forward to relocate to the } \\
\text { new project? }\end{array}$ & Text \\
\hline & $\begin{array}{l}\text { What different } \\
\text { introduction needs } \\
\text { exist }\end{array}$ & Q28 & $\begin{array}{l}\text { In what ways did learning the new } \\
\text { project differ from learning the old? }\end{array}$ & Text \\
\hline
\end{tabular}




\begin{tabular}{|c|c|c|c|}
\hline $\begin{array}{l}\text { Comparison } \\
\text { between } \\
\text { documentation } \\
\text { structures }\end{array}$ & Q29 & $\begin{array}{l}\text { (Statement) The test documentation } \\
\text { has a similar structure in both projects, } \\
\text { that helped me know where to look for } \\
\text { information }\end{array}$ & $\begin{array}{l}1-5 \\
(1=\text { disagree, } \\
5=\text { agree } \\
\text { completely }\end{array}$ \\
\hline $\begin{array}{l}\text { What part does the } \\
\text { amount of } \\
\text { customer contact } \\
\text { play in a } \\
\text { relocation? }\end{array}$ & Q30 & $\begin{array}{l}\text { Did you have more or less contact with } \\
\text { the customer after the relocation? } \\
\text { What did you think of that? }\end{array}$ & Text \\
\hline $\begin{array}{l}\text { Did a time factor } \\
\text { interfere with pro- } \\
\text { relocation learning? }\end{array}$ & Q31 & $\begin{array}{l}\text { (Statement) I had enough time for } \\
\text { preparation before relocation occurred }\end{array}$ & $\begin{array}{l}1-5 \\
(1=\text { disagree, } \\
5=\text { agree } \\
\text { completely }\end{array}$ \\
\hline $\begin{array}{l}\text { Project- } \\
\text { independent } \\
\text { knowledge } \\
\text { learned? }\end{array}$ & Q32 & $\begin{array}{l}\text { Were there any experiences from the } \\
\text { previous project that you had use for } \\
\text { in the new? }\end{array}$ & Text \\
\hline $\begin{array}{l}\text { Exposing } \\
\text { motivational } \\
\text { elements in } \\
\text { projects }\end{array}$ & Q33 & $\begin{array}{l}\text { Which of the projects felt the most } \\
\text { motivating and in what way? }\end{array}$ & Text \\
\hline $\begin{array}{l}\text { Invitations to } \\
\text { interviewees were } \\
\text { sent by mail if } \\
\text { interviewee showed } \\
\text { interest }\end{array}$ & Q34 & $\begin{array}{l}\text { Would you be interested in } \\
\text { participating in a quick computer- } \\
\text { based exercise that indicates what } \\
\text { learning style you prefer and what } \\
\text { personality you have? }\end{array}$ & yes/no \\
\hline
\end{tabular}




\section{C.2 INTERVIEW ANSWER LOG}

The tables below contain the actual notes taken during the eight consultant interviews. No interpretation or modification has been made except for direct translation from Swedish to English. A short description of abbreviations and note style used will precede the answer log.

\section{C.2.1 Note style and abbreviations}

- Auto

- Civ.engineer

- CS

- Dev/Devs

- Devlpmt

- LazyDog

- Part 1 / Part 2 (Project P1)

- $\quad \operatorname{Req} /$ reqs / req.spec

- Several others
A department separate from TestCenter (still at Cybercom) works with automated regression testing.

Swedish university degree "Civilingenjör", roughly comparable with MSc.

Computer science

Developer/s

Development

Step-by-step routines created and maintained internally by TestCenter staff.

Project P1 involves testing two different technologies separately. Some of the interviewees have preferred to refer talk separately of these. They have been called Part 1 and Part 2 in the answer $\log$.

Requirement / Requirements / Requirements specification

Regarding Question Q8. If more than one consultant was working with a project intended when the interviewee started there, notes will only write "Several others" to protect anonymity. No large principal difference should occur whether there were i.e. two, three or four consultants already. 


\section{C.2.2 Interviewees C1-C3}

Table C. 2. Interview answers from consultants C1-C3

\begin{tabular}{|c|c|c|c|c|c|}
\hline & & $\mathrm{C} 1$ & (C1 continued) & $\mathrm{C} 2$ & $\mathrm{C} 3$ \\
\hline Q1 & $\begin{array}{l}\text { For how long time have you } \\
\text { been working with testing in } \\
\text { Cybercom? }\end{array}$ & 36 months & $<-$ & $\begin{array}{c}3 \text { months (10 months w hour- } \\
\text { employment) }\end{array}$ & 9 months \\
\hline Q2 & $\begin{array}{l}\text { Did you have any education or } \\
\text { experience within software } \\
\text { testing before you started at } \\
\text { Cybercom? }\end{array}$ & No not in that area. Civil engineer. & $<-$ & $\begin{array}{l}\text { Not withing testing. Taken } \\
\text { programming courses (java) at } \\
\text { university. Course in user interfaces } \\
\text { was useful. MSc. }\end{array}$ & $\begin{array}{l}\text { Some testing in thesis work } \\
\text { (hardware). Has big similarities. Taken } \\
\text { some programming courses in } \\
\text { university (civ.engineer) }\end{array}$ \\
\hline Q3 & $\begin{array}{l}\text { Do you have any work } \\
\text { experience from other areas } \\
\text { within software development? }\end{array}$ & $\begin{array}{l}\text { Small experience, only hobby } \\
\text { projects, creating homepages with } \\
\text { databases and a little java } \\
\text { programming }\end{array}$ & $<-$ & thesis work with java development & Nothing except q2 \\
\hline Q4 & $\begin{array}{l}\text { Which test projects have you } \\
\text { worked in, and in what order? }\end{array}$ & Project P4 -> Project P1 -> Project P2 & $<-$ & Project P1 & $\begin{array}{c}\text { Project P1 -> Project P2 (-> Project P1 } \\
\text { (teamleader)) }\end{array}$ \\
\hline Q5 & $\begin{array}{l}\text { Is there any education area } \\
\text { where you would like to learn } \\
\text { more to make you an even } \\
\text { better test consultant in } \\
\text { general? }\end{array}$ & $\begin{array}{c}\text { Test types mainly; Performance } \\
\text { testing, load testing, exploratory } \\
\text { testing. }\end{array}$ & $<-$ & $\begin{array}{c}\text { Core technology tested in Project P1. } \\
\text { ISEB basic testing courses }\end{array}$ & $\begin{array}{l}\text { Project management. Test } \\
\text { management. ISEB testing courses } \\
\text { (part with test design). }\end{array}$ \\
\hline & & (Project P2) & (Project P4) & (Project P1) & (Project P2) \\
\hline Q6 & $\begin{array}{l}\text { When did you start working in } \\
\text { this project? }\end{array}$ & nov 2006. from beginning of devlpmt. & oct 2005 & $\begin{array}{l}\text { official apr 2007, but worked on hour- } \\
\text { basis along with thesis work several } \\
\text { months }\end{array}$ & $\begin{array}{c}\text { jan 2007. In parallel with Project P1 } \\
\text { especially near releases. }\end{array}$ \\
\hline Q7 & $\begin{array}{l}\text { Were there Cybercom test } \\
\text { consultants in the project } \\
\text { when you started? }\end{array}$ & $\begin{array}{c}\text { No TCs but } 7-8 \text { developers (not sure), } \\
1 \text { project leader. PL was also } \\
\text { testleader. All from Cybercom } \\
\end{array}$ & No but Cybercom developers & Yes several others & $\begin{array}{c}\text { Yes one test consultant. Before him } \\
\text { dev tested themselves. }\end{array}$ \\
\hline
\end{tabular}




\begin{tabular}{|c|c|c|c|c|c|}
\hline Q8 & $\begin{array}{l}\text { Can you tell me about how } \\
\text { you learned to work in the } \\
\text { project? }\end{array}$ & $\begin{array}{l}\text { Learning-by-doing. Asking } \\
\text { developers. Try to find docs. No real } \\
\text { introduction. No test plan existed. }\end{array}$ & $\begin{array}{l}\text { learning-by-doing. "here, test this". } \\
\text { Could learn from some old test specs } \\
\text { and test cases }\end{array}$ & $\begin{array}{l}\text { Got brief overview introduction by PM. } \\
\text { Started hands-on with a static and } \\
\text { easy-to-learn part of Project P1. } \\
\text { Someone showed where stuff were. } \\
\text { (tools, docs). If something unclear } \\
\text { asked someone of the others, often } \\
\text { one with long experience. Then a little } \\
\text { more difficult part of Project P1. Had to } \\
\text { learn interpreting test specs, especially } \\
\text { when having to use hardware tool for } \\
\text { testing. Hard to understand because } \\
\text { had no knowledge of the core tech of } \\
\text { that Project P1 part. Asked others if } \\
\text { hard to decide if correct or not. }\end{array}$ & $\begin{array}{l}\text { Mostly learning by doing. Sat with } \\
\text { devs. Some general test cases } \\
\text { existed. Learned more intensely close } \\
\text { to releases. Not much documentation. } \\
\text { Wrote lots of test cases, also on } \\
\text { paper. }\end{array}$ \\
\hline Q9 & $\begin{array}{l}\text { What was the biggest } \\
\text { challenge with learning to } \\
\text { work in this project? }\end{array}$ & $\begin{array}{l}\text { Writing testcases from scratch. } \\
\text { Difficult - non-existant/incorrect } \\
\text { requirements. Had to make req } \\
\text { hypotheses + verify with developers. } \\
\text { Difficult to know how product should } \\
\text { look. Contact w. developers itself was } \\
\text { a challenge. But they were helpful. }\end{array}$ & & $\begin{array}{l}\text { The second more difficult part of } \\
\text { Project P1, understanding test specs. }\end{array}$ & Project meetings. Terminology. \\
\hline Q10 & $\begin{array}{l}\text { Was there anything that felt } \\
\text { stressing? }\end{array}$ & No possibly that reqs were incorrect & (question added later) & no & $\begin{array}{l}\text { Not really. Not enough time to test } \\
\text { everything needed, low staffing. } \\
\text { Insufficient documentation }\end{array}$ \\
\hline Q11 & $\begin{array}{l}\text { How large practical } \\
\text { importance did you feel that } \\
\text { learning with the use of } \\
\text { mentor or other person got in } \\
\text { relation to how much you } \\
\text { could learn by studying } \\
\text { documentation? }\end{array}$ & $\begin{array}{l}\text { Documentation incorrect and hardly } \\
\text { updated. Communication (w. } \\
\text { developers) much more important. TL } \\
\text { was not very familiar. } 30 \% \text { by project } \\
\text { documentation. Not much of test doc, } \\
\text { no test plan. TL didnt care much } \\
\text { about how testing was done } \\
\end{array}$ & $\begin{array}{l}\text { More documentation than Project P2. } \\
\text { Not much test doc but clearer } \\
\text { requirements + some mockups. More } \\
\text { of a ground to start from. } \sim 80 \% \text { doc }\end{array}$ & $\begin{array}{l}70 \% \text { by asking others. No individual } \\
\text { mentoring at that time. Believes in } \\
\text { mentorship. More nice and personal } \\
\text { have someone to turn to. Also not } \\
\text { possible w. sufficient docs when they } \\
\text { are responsibility of customer to } \\
\text { produce, thus personal comm. } \\
\text { Necessary (both part1 and } 2 \text { of Project } \\
\text { P1) } \\
\end{array}$ & $\begin{array}{l}\text { Mostly by asking others (devs). About } \\
\text { specs. Good w this comm. More doc } \\
\text { would have been needed, could not } \\
\text { prepare thoroughly. }\end{array}$ \\
\hline Q12 & $\begin{array}{l}\text { How long time did it take for } \\
\text { you to become self-propelled? }\end{array}$ & $\begin{array}{l}\text { At least a month. Not full-time, } 25 \% \text { - } \\
50 \% \text { part time }\end{array}$ & About 1 week. Smaller project & $\begin{array}{l}\text { 1st part } 2 \text { days, } 2 \text { nd part couple of } \\
\text { weeks. Hard to draw limit. These times } \\
\text { for everyday work, is still learning. }\end{array}$ & A couple, maybe three weeks. \\
\hline
\end{tabular}




\begin{tabular}{|c|c|c|c|c|c|}
\hline Q13 & $\begin{array}{l}\text { Was the introduction and } \\
\text { learning part of the project } \\
\text { optimal? Do you think it could } \\
\text { be improved? }\end{array}$ & & & $\begin{array}{l}\text { Probably could be better if had a } \\
\text { specific mentor also during hour- } \\
\text { employment. Partly that the person } \\
\text { asked didnt need to be disturbed } \\
\text { without knowing why }\end{array}$ & $\begin{array}{l}\text { More documentation had been good. } \\
\text { Hard to know what needed to be } \\
\text { tested. Hard to know how much time } \\
\text { was available, too much to do in the } \\
\text { end. Many questions to ask - but } \\
\text { communication is positive. Good } \\
\text { working close to devs, simple to ask } \\
\text { questions aloud. Some admin } \\
\text { mishapps like not getting login account } \\
\text { in time. }\end{array}$ \\
\hline Q14 & $\begin{array}{l}\text { Did you have any contact with } \\
\text { the customer? Could you } \\
\text { solve the questions and } \\
\text { issues that arose? }\end{array}$ & (question added later) & & $\begin{array}{l}\text { none. There are a few spokesmen } \\
\text { towards customer and that is good, not } \\
\text { asking same questions twice. }\end{array}$ & $\begin{array}{l}\text { Not at beginning. He became inofficial } \\
\text { contact person between cybercom and } \\
\text { customer then. A little difficult he did } \\
\text { not have all details. When first } \\
\text { consultant was disconnected from } \\
\text { project. Non-test related argues } \\
\text { ("throwing pies") took too much time } \\
\text { (between two different departments } \\
\text { with responsibilities for developing } \\
\text { different parts of system). }\end{array}$ \\
\hline Q15 & $\begin{array}{l}\text { How well did you know the } \\
\text { software development model } \\
\text { in the project before you } \\
\text { begun? }\end{array}$ & $\begin{array}{l}\text { Not at all. Not even what language } \\
\text { should be used. } 1 / 5\end{array}$ & A little about it being iterative only. $1 / 5$ & Not at all. Still nothing. $1 / 5$ & $\begin{array}{l}\text { Only little. They did not participate in } \\
\text { dev meetings from beginning, } \\
\text { discovered this valuable (agile) }\end{array}$ \\
\hline Q16 & $\begin{array}{l}\text { Did you before or during the } \\
\text { project receive any kind of } \\
\text { formal education, including } \\
\text { education at customer site? }\end{array}$ & $\begin{array}{l}\text { Not really. A developer had } 2 \mathrm{~h} \\
\text { presentation about tool on server to } \\
\text { help test clients. }\end{array}$ & $\begin{array}{c}\text { Not really. 1-hour intro before + } \\
\text { demonstration of device flash } \\
\text { program. Nobody showed where } \\
\text { documentation was } \\
\end{array}$ & $\begin{array}{l}\text { No nothing. Only summaries from } \\
\text { other consultants course experiences }\end{array}$ & No \\
\hline Q17 & $\begin{array}{l}\text { Do you think you could have } \\
\text { had use of any further } \\
\text { education for the sake of this } \\
\text { specific project? }\end{array}$ & $\begin{array}{l}\text { Yes in the beginning. Both of the } \\
\text { programs developed and test tools. } \\
\text { i.e. error reporting system. All could } \\
\text { have use of such. Knowledge of } \\
\text { performance testing would been good }\end{array}$ & $\begin{array}{l}\text { The test mananagement system used } \\
\text { (both reqs, test cases, bug reporting) }\end{array}$ & $\begin{array}{l}\text { Yes, general ISEB course. And core } \\
\text { tech of Project P1. Need it to being } \\
\text { able to ask coretech experts at the } \\
\text { customer site. }\end{array}$ & $\begin{array}{l}\text { Designing tests. ISEB advanced parts } \\
\text { maybe. A course in Consultant- } \\
\text { Customer communication }\end{array}$ \\
\hline & & & & & \\
\hline
\end{tabular}




\begin{tabular}{|c|c|c|c|c|c|}
\hline Q18 & $\begin{array}{l}\text { (Statement) The different } \\
\text { parts of test documentation } \\
\text { are gathered in one place? }\end{array}$ & & & 3 & \\
\hline Q19 & $\begin{array}{l}\text { (Statement) The coverage of } \\
\text { existing test documentation } \\
\text { was sufficient enough for my } \\
\text { needs }\end{array}$ & & & part1; 4. part2; 3 & \\
\hline Q20 & $\begin{array}{l}\text { (Statement) The information in } \\
\text { existing test documentation } \\
\text { was constantly updated and } \\
\text { correct }\end{array}$ & & & part1; 2, part2: 3 & \\
\hline Q21 & $\begin{array}{l}\text { (Statement) The contents of } \\
\text { existing test documentation } \\
\text { was easy to understand }\end{array}$ & & & part1; 4, part2: 3 & \\
\hline Q22 & $\begin{array}{l}\text { What type of information or } \\
\text { presentation would make it } \\
\text { (documentation) even better? }\end{array}$ & $\begin{array}{l}\text { *How to create test specs, } \\
\text { guidelines/tips/tricks. *Clear test } \\
\text { process - whole flow (bug reports } \\
\text { could be given to a developer who } \\
\text { picked it up, fixed the problem and } \\
\text { then it disappeared. }{ }^{*} \text { List of contact } \\
\text { persons } \\
\end{array}$ & $\begin{array}{c}\text { Lazydog for the test management } \\
\text { system. People and their } \\
\text { responsibilities }\end{array}$ & $\begin{array}{l}\text { test specs and tech specs from } \\
\text { customer, and has own LazyDogs for } \\
\text { both part } 1 \text { and } 2 \text {. More step-by-step } \\
\text { instructions. Less massive text. For } \\
\text { both parts of Project P1. }\end{array}$ & $\begin{array}{l}\text { Devs had some documentation about } \\
\text { how system should work. More } \\
\text { information about this would be good, } \\
\text { i.e. flowcharts over functionality. }\end{array}$ \\
\hline Q23 & $\begin{array}{l}\text { What properties in working } \\
\text { with this project felt } \\
\text { motivating? }\end{array}$ & $\begin{array}{l}\text { Writing test specs. Test design }= \\
\text { creativity. Making performance tests. } \\
\text { Had to learn everything and create a } \\
\text { test process himself }=\text { most } \\
\text { motivating and inspiring. }\end{array}$ & $\begin{array}{l}\text { Everything was new. Test design. } \\
\text { Participating during whole } \\
\text { dev.process. Creation of virtual } \\
\text { requirements to enable testing. }\end{array}$ & the technical challenge in part 2 & $\begin{array}{l}\text { Had influence on many parts. could try } \\
\text { many new areas. Test design and dev } \\
\text { meetings - early insight into product }\end{array}$ \\
\hline \multirow[t]{2}{*}{ Q24 } & $\begin{array}{l}\text { Did the work demand any } \\
\text { creativity to be done? In what } \\
\text { ways? }\end{array}$ & $\begin{array}{l}\text { Yes very much.Writing test specs. To } \\
\text { find different ways to execute to } \\
\text { pinpoint an error. }\end{array}$ & Same as the motivating factors & $\begin{array}{l}\text { Not really. Much work is pre-specified } \\
\text { exactly. Possibly administrational work } \\
\text { like writing routines (has updated } \\
\text { LazyDog for Project P1) }\end{array}$ & $\begin{array}{l}\text { Yes, designing tests. System is user } \\
\text { oriented, he is interested in user } \\
\text { orientation /user interfaces. Could } \\
\text { influence user interface design }\end{array}$ \\
\hline & & (Project P1->Project P2) & & & (Project P1->Project P2) \\
\hline Q25 & $\begin{array}{l}\text { When did you change project } \\
\text { the last time? }\end{array}$ & nov 2006 & & no project relocation & $\begin{array}{l}\text { apr } 2007 \text { (but hard to draw line, part- } \\
\text { time during long time on both projects) }\end{array}$ \\
\hline Q26 & $\begin{array}{l}\text { Who took the initiative for the } \\
\text { relocation? }\end{array}$ & the manager of Veritech & & no project relocation & PM \\
\hline
\end{tabular}




\begin{tabular}{|c|c|c|c|c|}
\hline Q27 & $\begin{array}{l}\text { Did you look forward to } \\
\text { relocate to the new project? }\end{array}$ & $\begin{array}{l}\text { yes very much, great challenge. } \\
\text { Exciting with something new. Looked } \\
\text { forward to responsibility of test leader }\end{array}$ & no project relocation & $\begin{array}{l}\text { Yes seemed to have much potential to } \\
\text { learn new things. }\end{array}$ \\
\hline Q28 & $\begin{array}{l}\text { In what ways did learning the } \\
\text { new project differ from } \\
\text { learning the old? }\end{array}$ & $\begin{array}{l}\text { Project P2 thrown in. Asking } \\
\text { developers can be hard, knowing who } \\
\text { to ask and afraid to bother them. }\end{array}$ & no project relocation & $\begin{array}{l}\text { Exist more documentation in Project } \\
\text { P1. Learning by doing in both projects. } \\
\text { Easier to find answers in doc in Project } \\
\text { P1. }\end{array}$ \\
\hline Q29 & $\begin{array}{l}\text { (Statement) The test } \\
\text { documentation has a similar } \\
\text { structure in both projects, that } \\
\text { helped me know where to look } \\
\text { for information }\end{array}$ & $\begin{array}{c}\text { 1/5. (no doc in Project P2. Only little } \\
\text { in Project P1, tips \& tricks). I did not } \\
\text { have time (only parttime) to create } \\
\text { test documentation, easier to ask } \\
\text { developer }\end{array}$ & no project relocation & 2 \\
\hline Q30 & $\begin{array}{l}\text { Did you have more or less } \\
\text { contact with the customer } \\
\text { after the relocation? What did } \\
\text { you think of that? }\end{array}$ & $\begin{array}{c}\text { quite similar. Project P1 daily contact. } \\
\text { Little less on Project P2 }\end{array}$ & no project relocation & $\begin{array}{l}\text { Less but still exist. Contact with } \\
\text { customer nice. Some friends working } \\
\text { at the customer site, helped. }\end{array}$ \\
\hline Q31 & $\begin{array}{l}\text { (Statement) I had enough time } \\
\text { for preparation before } \\
\text { relocation occurred }\end{array}$ & $\begin{array}{c}1 / 5 \text { ("in two weeks you will change", } \\
\text { no time before to prepare). Would } \\
\text { have been valuable with a little more } \\
\text { time }\end{array}$ & no project relocation & \\
\hline Q32 & $\begin{array}{l}\text { Were there any experiences } \\
\text { from the previous project that } \\
\text { you had use for in the new? }\end{array}$ & $\begin{array}{l}\text { Most was new. Had used the same } \\
\text { bug reporting system in the last } \\
\text { project. Some knowledge of the } \\
\text { customers product philosophy and } \\
\text { terminology. Some knowledge from } \\
\text { writing test specs in Project P4 }\end{array}$ & no project relocation & $\begin{array}{l}\text { Not much. Basic test philosophy. } \\
\text { Having frequent meetings good for } \\
\text { creating common goals (scrum). }\end{array}$ \\
\hline Q33 & $\begin{array}{l}\text { Which of the projects felt the } \\
\text { most motivating and in what } \\
\text { way? }\end{array}$ & $\begin{array}{l}\text { The first (Project P1) because I came } \\
\text { directly from school. + expactations of } \\
\text { working with the customer (well- } \\
\text { known company) }\end{array}$ & no project relocation & $\begin{array}{c}\text { Project P2 more motivating first, much } \\
\text { to lay hands upon. Project P1 more } \\
\text { motivating now when has team leader } \\
\text { role. }\end{array}$ \\
\hline Q34 & $\begin{array}{l}\text { Would you be interested in } \\
\text { participating in a quick } \\
\text { computer-based exercise that } \\
\text { indicates what learning style } \\
\text { you prefer and what } \\
\text { personality you have? }\end{array}$ & Yes & Yes & Yes \\
\hline
\end{tabular}




\section{C.2.3 Interviewees C4-C8}

Table C. 3. Interview answers from consultants C4-C8

\begin{tabular}{|c|c|c|c|c|c|c|}
\hline & & $\mathrm{C} 4$ & $\mathrm{C} 5$ & C6 & $\mathrm{C} 7$ & $\mathrm{C} 8$ \\
\hline Q1 & $\begin{array}{l}\text { For how long time have } \\
\text { you been working with } \\
\text { testing in Cybercom? }\end{array}$ & 120 months & 1,5 months & 18 months & 6 months & 2 months \\
\hline Q2 & $\begin{array}{l}\text { Did you have any } \\
\text { education or experience } \\
\text { within software testing } \\
\text { before you started at } \\
\text { Cybercom? }\end{array}$ & $\begin{array}{l}\text { Programming courses on } \\
\text { university (civ.engineer). No } \\
\text { specific test courses }\end{array}$ & $\begin{array}{l}\text { University courses } \\
\text { (civ.engineer). Mixed } \\
\text { programming courses. }\end{array}$ & $\begin{array}{c}\text { University courses in } \\
\text { programming and computer } \\
\text { science. }\end{array}$ & $\begin{array}{c}\text { several programming courses } \\
\text { in university, civ.engineering in } \\
\text { CS }\end{array}$ & $\begin{array}{l}\text { java programming courses } \\
\text { university. Civ.eng electro- } \\
\text { design. }\end{array}$ \\
\hline Q3 & $\begin{array}{l}\text { Do you have any work } \\
\text { experience from other } \\
\text { areas within software } \\
\text { development? }\end{array}$ & $\begin{array}{l}\text { Some programming for } \\
\text { telephone switchboards, } \\
\text { patches in assembler. }\end{array}$ & No & $\begin{array}{l}\text { Worked with it consultancy for a } \\
\text { year. Worked with content } \\
\text { management. User interface } \\
\text { development. Testing from user } \\
\text { perspective, ad-hoc. Some VB } \\
\text { development. }\end{array}$ & $\begin{array}{c}\text { No not except university devpt } \\
\text { projects }\end{array}$ & thesis work with c\# devipmt. \\
\hline Q4 & $\begin{array}{l}\text { Which test projects have } \\
\text { you worked in, and in } \\
\text { what order? }\end{array}$ & $\begin{array}{l}\text { automated testing (outside } \\
\text { testcenter) -> Project P1 }\end{array}$ & Project P1 (part1+2) & Project P1 -> Project P3. & Project P4 -> Project P3 & $\begin{array}{c}\text { (Project P4) -> Project P2 } \\
\text { (Project P4 only couple of } \\
\text { hours) }\end{array}$ \\
\hline Q5 & $\begin{array}{l}\text { Is there any education } \\
\text { area where you would } \\
\text { like to learn more to } \\
\text { make you an even better } \\
\text { test consultant in } \\
\text { general? }\end{array}$ & No & $\begin{array}{l}\text { Not his area. Thinks technical } \\
\text { education could be valuable } \\
\text { for testers }\end{array}$ & $\begin{array}{l}\text { Quality management, } \\
\text { requirements engineering, } \\
\text { security testing }\end{array}$ & $\begin{array}{l}\text { Test management. ISEB part } \\
\text { "Practitioner". Management } \\
\text { courses in general }\end{array}$ & $\begin{array}{l}\text { Test development (test design, } \\
\text { test coverage). "Difficult to have } \\
\text { a critical look on testing when } \\
\text { lacking theoretical background". } \\
\text { Has learned from how others } \\
\text { have done }\end{array}$ \\
\hline & & (Project P1) & (Project P1) & (Project P3) & (Project P3) & (Project P2) \\
\hline
\end{tabular}




\begin{tabular}{|c|c|c|c|c|c|c|}
\hline Q6 & $\begin{array}{l}\text { When did you start } \\
\text { working in this project? }\end{array}$ & dec 2006 & Jun 2007 & $\begin{array}{c}\text { july } 2007 \text { ( } 2 \text { weeks before } \\
\text { interview) }\end{array}$ & feb 2007 & may 2007 \\
\hline Q7 & $\begin{array}{l}\text { Were there Cybercom } \\
\text { test consultants in the } \\
\text { project when you } \\
\text { started? }\end{array}$ & Several others & yes several & yes one & yes one & several \\
\hline Q8 & $\begin{array}{l}\text { Can you tell me about } \\
\text { how you learned to work } \\
\text { in the project? }\end{array}$ & $\begin{array}{l}\text { Started w part1 of Project } \\
\text { P1. Mostly learning by } \\
\text { asking. People showed how } \\
\text { it was done. }\end{array}$ & $\begin{array}{l}\text { Old tests in part 1. Later same } \\
\text { day "sharp". Part } 1 \text { the whole } \\
\text { week. Had an official mentor } \\
\text { appointed. Second week part } \\
\text { 2. Much use of LazyDog. }\end{array}$ & $\begin{array}{l}\text { At customer location. Small } \\
\text { introduction from the other } \\
\text { consultant. Worked beside him } \\
\text { for a week. Writing test cases. } \\
\text { Not seen any requirements. } \\
\text { Only from a user guide. } \\
\end{array}$ & $\begin{array}{l}\text { Cybercom-consultant passed } \\
\text { over in } 2 \text { days. Gave a quick } \\
\text { introduction, showed a part of } \\
\text { the system Much too quick. } \\
\text { 1st consultant had made a } \\
\text { folder with links to various } \\
\text { docs, that was good. Also got } \\
\text { a mentor at the customer. }\end{array}$ & $\begin{array}{l}\text { Overview presentation inc } \\
\text { project-specific tools. Had an } \\
\text { individual learning plan. Sat next } \\
\text { to other consultant, tried one tool } \\
\text { at a time. Asking questions. } \\
\text { Then learning error reporting } \\
\text { system. Then creating test } \\
\text { cases. Used old test cases. Got } \\
\text { in contact with devs when sharp } \\
\text { testing begun. User guides } \\
\text { existed, well-documented. } \\
\text { Helped writing in a lazydog. }\end{array}$ \\
\hline Q9 & $\begin{array}{l}\text { What was the biggest } \\
\text { challenge with learning } \\
\text { to work in this project? }\end{array}$ & $\begin{array}{l}\text { Lost contact with } \\
\text { developers, only allowed to } \\
\text { go through team contact } \\
\text { persons }\end{array}$ & $\begin{array}{c}\text { How to find project } \\
\text { information. How to classify } \\
\text { test cases. }\end{array}$ & $\begin{array}{l}\text { To understand how the whole } \\
\text { system works, is only involved in } \\
\text { one of the parts. }\end{array}$ & $\begin{array}{l}\text { To understand the technology } \\
\text { (hardware). Had to ask } \\
\text { people. Existed a (bad) } \\
\text { req.spec. Hard to get security } \\
\text { access to all documentation. } \\
\text { Cybercom would need to } \\
\text { create documentation of their } \\
\text { own } \\
\end{array}$ & $\begin{array}{l}\text { Having to learn the tools very } \\
\text { quickly to start sharp almost } \\
\text { immediately. Hard to choose } \\
\text { what should be tested. }\end{array}$ \\
\hline Q10 & $\begin{array}{l}\text { Was there anything that } \\
\text { felt stressing? }\end{array}$ & Q10 & $\begin{array}{l}\text { When tests do not pass. } \\
\text { Sometimes when behavior of } \\
\text { test execution is inconsistent } \\
\text { from time to time. Boring when } \\
\text { device builds are not received } \\
\text { in time. }\end{array}$ & $\begin{array}{l}\text { Does not feel part of the } \\
\text { customer team yet. Not sure if } \\
\text { customer even knows she will } \\
\text { work there fulltime. Difficult to } \\
\text { make contact with customer. } \\
\text { Also still has to transfer Project } \\
\text { P1 knowledge because she was } \\
\text { the most experienced. }{ }^{*}\end{array}$ & $\begin{array}{l}\text { The test leader could not } \\
\text { provide with enough } \\
\text { information. A bit hard to be } \\
\text { thrown in that quick, difficult } \\
\text { becoming accepted socially, } \\
\text { took some energy in the } \\
\text { beginning. }\end{array}$ & $\begin{array}{l}\text { No. Fun to work "for real". Was } \\
\text { skeptical towards testing first, } \\
\text { rumors that was boring. It was } \\
\text { fun; test design test cases, close } \\
\text { contact with developers. }\end{array}$ \\
\hline
\end{tabular}




\begin{tabular}{|c|c|c|c|c|c|}
\hline Q11 & $\begin{array}{l}\text { How large practical } \\
\text { importance did you feel } \\
\text { that learning with the } \\
\text { use of mentor or other } \\
\text { person got in relation to } \\
\text { how much you could } \\
\text { learn by studying } \\
\text { documentation? }\end{array}$ & $\begin{array}{l}90 \% \text { mentor, } 10 \% \\
\text { documentation }\end{array}$ & $\begin{array}{l}\text { first week only the mentor. } \\
\text { Discovered lazydog then, went } \\
\text { over completely. Mostly } \\
\text { documentation. }\end{array}$ & $\begin{array}{l}\text { During first release much } \\
\text { communication, second could } \\
\text { use more documentation when } \\
\text { used to it. }\end{array}$ & $\begin{array}{l}\text { The personal communication } \\
\text { large }(30 \%) \text {, and very good. } \\
\text { Contact with devs much faster } \\
\text { than through documentation } \\
(20 \%) . \text { "Clicking around" by self } \\
50 \% \text {. Only doc gives not enough } \\
\text { connection to reality, need to } \\
\text { see the real thing also. }\end{array}$ \\
\hline Q12 & $\begin{array}{l}\text { How long time did it take } \\
\text { for you to become self- } \\
\text { propelled? }\end{array}$ & $\begin{array}{l}\text { Part } 1 \text { almost immediately, } \\
\text { Part } 2 \text { difficult to answer, still } \\
\text { learning. }\end{array}$ & 2 days for each part & 3 weeks & 3 weeks, \\
\hline Q13 & $\begin{array}{l}\text { Was the introduction } \\
\text { and learning part of the } \\
\text { project optimal? Do you } \\
\text { think it could be } \\
\text { improved? }\end{array}$ & $\begin{array}{l}\text { Not optimal but fairly good, } \\
\text { proc has been constantly } \\
\text { improving (especially docs). } \\
\text { Doc becomes more } \\
\text { important in Part } 2 .\end{array}$ & Yes & $\begin{array}{l}\text { No. Needed a req specs, must } \\
\text { exist. There is one now. } \\
\text { Perhaps one in different } \\
\text { levels, reached more details } \\
\text { gradually. Draft of software } \\
\text { architecture, creates feeling of } \\
\text { confidence having an } \\
\text { overview. Perhaps much of } \\
\text { the verbal knowledge could } \\
\text { been written. Good idea with } \\
\text { the link folder. }\end{array}$ & $\begin{array}{l}\text { Good introduction (esp. Tools, } \\
\text { goal w project, deliverables. } \\
\text { That there was a learning plan. } \\
\text { But perhaps a bit hectic and } \\
\text { messy (even if good w early dev } \\
\text { contact). Perhaps same } \\
\text { questions was asked by both the } \\
\text { testcenter consultants. There } \\
\text { were daily meetings at } \\
\text { developer site, could have been } \\
\text { good if attended more of those. }\end{array}$ \\
\hline Q14 & $\begin{array}{l}\text { Did you have any } \\
\text { contact with the } \\
\text { customer? Could you } \\
\text { solve the questions and } \\
\text { issues that arose? }\end{array}$ & No (Q10) & $\begin{array}{l}\text { No contact. Going through } \\
\text { contact persons. Questions } \\
\text { can halt some time because of } \\
\text { this. }\end{array}$ & $\begin{array}{c}\text { Yes located at customer site. } \\
\text { Could solve problems (see } \\
\text { also Q10b) }\end{array}$ & No \\
\hline Q15 & $\begin{array}{l}\text { How well did you know } \\
\text { the software } \\
\text { development model in } \\
\text { the project before you } \\
\text { begun? }\end{array}$ & Not much & 1 & $\begin{array}{c}\text { Neither before nor in the } \\
\text { beginning. } 1 .\end{array}$ & $\begin{array}{l}\text { Not at all. 1. Didnt visit daily } \\
\text { meetings. Still dont no much, } \\
\text { only noticeable by frequent } \\
\text { changes in functionality. Only } \\
\text { functionality tests. }\end{array}$ \\
\hline
\end{tabular}




\begin{tabular}{|c|c|c|c|c|c|}
\hline Q16 & $\begin{array}{l}\text { Did you before or during } \\
\text { the project receive any } \\
\text { kind of formal education, } \\
\text { including education at } \\
\text { customer site? }\end{array}$ & $\begin{array}{l}\text { No education. Only brief } \\
\text { presentation/overview }\end{array}$ & No & $\begin{array}{l}\text { A 2day course about test } \\
\text { design. Interviewee had to } \\
\text { suggest it. Could later sell this } \\
\text { to customer. Also a course in } \\
\text { python, customer took } \\
\text { initiative. }\end{array}$ & $\begin{array}{l}\text { Not formal. Small information } \\
\text { introductions at TestCenter. }\end{array}$ \\
\hline Q17 & $\begin{array}{l}\text { Do you think you could } \\
\text { have had use of any } \\
\text { further education for the } \\
\text { sake of this specific } \\
\text { project? }\end{array}$ & $\begin{array}{c}\text { internal courses at customer } \\
\text { (technical). ISEB courses } \\
\text { perhaps }\end{array}$ & $\begin{array}{l}\text { No, mentor is enough, to show } \\
\text { tools + things that usually } \\
\text { cause problems. Perhaps } \\
\text { more education for more } \\
\text { advanced part of Part } 2 \\
\text { instead of trying to interpret } \\
\text { reference logs. }\end{array}$ & $\begin{array}{l}\text { Not really. Performance or } \\
\text { load testing perhaps. Web } \\
\text { applications. }\end{array}$ & $\begin{array}{l}\text { Maybe ISEB. Company prefer if } \\
\text { self-study it. Courses/education } \\
\text { is positive. A 2-day course } \\
\text { before testing would be optimal. } \\
\text { How to cover what needs to be } \\
\text { tested, test design. Software } \\
\text { tools for supporting test } \\
\text { methods; ie performance testing }\end{array}$ \\
\hline & & & & & \\
\hline Q18 & $\begin{array}{l}\text { (Statement) The } \\
\text { different parts of test } \\
\text { documentation are } \\
\text { gathered in one place? } \\
\end{array}$ & 2 & 4 & & \\
\hline Q19 & $\begin{array}{l}\text { (Statement) The } \\
\text { coverage of existing test } \\
\text { documentation was } \\
\text { sufficient enough for my } \\
\text { needs }\end{array}$ & 3 & 3 & & \\
\hline Q20 & $\begin{array}{l}\text { (Statement) The } \\
\text { information in existing } \\
\text { test documentation was } \\
\text { constantly updated and } \\
\text { correct }\end{array}$ & 4 & $\begin{array}{c}3 \text { (certain things in lazydog } \\
\text { outdated) }\end{array}$ & & \\
\hline
\end{tabular}




\begin{tabular}{|c|c|c|c|c|c|c|}
\hline Q21 & $\begin{array}{l}\text { (Statement) The } \\
\text { contents of existing test } \\
\text { documentation was easy } \\
\text { to understand }\end{array}$ & 4 & 4 & & & \\
\hline - & & & & & & \\
\hline Q22 & $\begin{array}{l}\text { What type of information } \\
\text { or presentation would } \\
\text { make it (documentation) } \\
\text { even better? }\end{array}$ & $\begin{array}{l}\text { Good thing that everyone } \\
\text { fills in w tips and tricks } \\
\text { (lazydog). But no } \\
\text { motivations exist for test } \\
\text { cases. Mentality of Project } \\
\mathrm{P} 1 \text { hard to understand - } \\
\text { running same test the same } \\
\text { way } 20 \text { times and settling } \\
\text { with } 1 \text { pass. } \\
\end{array}$ & $\begin{array}{l}\text { Graphical illustrations. } \\
\text { Different tabs have the same } \\
\text { name. Bulleted text form is } \\
\text { more clear, easily read, than } \\
\text { long text. }\end{array}$ & & $\begin{array}{c}\text { Where different docs are } \\
\text { placed, req specs, software } \\
\text { design. +Q12b }\end{array}$ & $\begin{array}{l}\text { There were no req.specs, only } \\
\text { mockups. Missed that. } \\
\text { Requirements often comm. } \\
\text { verbally to the other test } \\
\text { consultant. }\end{array}$ \\
\hline Q23 & $\begin{array}{l}\text { What properties in } \\
\text { working with this project } \\
\text { felt motivating? }\end{array}$ & $\begin{array}{c}\text { It is more motivating than } \\
\text { working with automated } \\
\text { testing - can see what you } \\
\text { do. }\end{array}$ & $\begin{array}{l}\text { When you try the same thing } \\
\text { many times and have some } \\
\text { luck. Feels a bit hard when } \\
\text { you can't get a pass. Like you } \\
\text { are contributing with nothing } \\
\text { new. Also motivation from } \\
\text { switching regularly between } \\
\text { part } 1 \text { and } 2 \text {. }\end{array}$ & $\begin{array}{l}\text { Project P1: There from start, had } \\
\text { to figure everything out. How to } \\
\text { test. Later how to learn others. } \\
\text { Understanding logs of part } 2 \\
\text { advanced testing. }\end{array}$ & $\begin{array}{l}\text { Test design was motivating in } \\
\text { the beginning, not anymore. } \\
\text { Motivation in learning all parts } \\
\text { of system. Basic motivation of } \\
\text { wanting to do good job, } \\
\text { removing bugs. }\end{array}$ & $\begin{array}{l}\text { Got large responsibility from the } \\
\text { start. The whole test area was } \\
\text { new. }\end{array}$ \\
\hline \multirow[t]{2}{*}{ Q24 } & $\begin{array}{l}\text { Did the work demand } \\
\text { any creativity to be } \\
\text { done? In what ways? }\end{array}$ & No & $\begin{array}{l}\text { Quite one-sided work. Not } \\
\text { much room for creativity. Part } \\
\text { two perhaps a bit more in } \\
\text { means of choosing right test } \\
\text { method for passing. Also doc } \\
\text { in more advanced part } 2 \text { is } \\
\text { insufficient, creativity needed } \\
\text { then. If doc too good, work can } \\
\text { become boring. }\end{array}$ & $\begin{array}{l}\text { Project P1: Yes to get the tests } \\
\text { through (adjusting method). }\end{array}$ & $\begin{array}{l}\text { Yes. Ex. to find memory leak, } \\
\text { customer devlpmt was stalled. } \\
\text { Had to unit test to solve. }\end{array}$ & $\begin{array}{l}\text { Not really, templates for test } \\
\text { cases existed from beginning. } \\
\text { Adjusted them, but has been } \\
\text { much other to learn. }\end{array}$ \\
\hline & & (Auto->Project P1) & & Project P1->Project P3 & & \\
\hline Q25 & $\begin{array}{l}\text { When did you change } \\
\text { project the last time? }\end{array}$ & $\operatorname{dec} 2006$ & no project relocation & july 2007 & march 2007 & no project relocation \\
\hline
\end{tabular}




\begin{tabular}{|c|c|c|c|c|c|c|}
\hline Q26 & $\begin{array}{l}\text { Who took the initiative } \\
\text { for the relocation? }\end{array}$ & The interviewed consultant & no project relocation & The interviewed consultant. & $\begin{array}{l}\text { own initiative first, PM asked } \\
\text { later. }\end{array}$ & no project relocation \\
\hline Q27 & $\begin{array}{l}\text { Did you look forward to } \\
\text { relocate to the new } \\
\text { project? }\end{array}$ & Yes & no project relocation & $\begin{array}{l}\text { Yes, was promised fast } \\
\text { advancement. }\end{array}$ & Yes (own initiative) & no project relocation \\
\hline Q28 & $\begin{array}{l}\text { In what ways did } \\
\text { learning the new project } \\
\text { differ from learning the } \\
\text { old? }\end{array}$ & $\begin{array}{c}\text { Learning was more } \\
\text { structured at Auto, had an } \\
\text { advisor, well specified } \\
\text { WHAT she should learn. } \\
\text { More fuzzy when starting } \\
\text { Project P1, everyone should } \\
\text { know everything. Auto was } \\
\text { bigger, had to split into } \\
\text { dedicated areas of } \\
\text { knowledge } \\
\end{array}$ & no project relocation & & $\begin{array}{l}\text { Project P4 very small, was } \\
\text { alone there. There were } \\
\text { req.specs and some mockups, } \\
\text { and work more integrated w. } \\
\text { devs. Project P3 much bigger } \\
\text { to learn }\end{array}$ & no project relocation \\
\hline Q29 & $\begin{array}{l}\text { (Statement) The test } \\
\text { documentation has a } \\
\text { similar structure in both } \\
\text { projects, that helped me } \\
\text { know where to look for } \\
\text { information }\end{array}$ & $\begin{array}{l}\text { 1. Good thing with Project } \\
\mathrm{P} 1 \text { doc is that you can edit } \\
\text { yourself. Auto docs more } \\
\text { formal/professional. }\end{array}$ & no project relocation & 1 & 1 & no project relocation \\
\hline Q30 & $\begin{array}{l}\text { Did you have more or } \\
\text { less contact with the } \\
\text { customer after the } \\
\text { relocation? What did you } \\
\text { think of that? }\end{array}$ & Less (q10) & no project relocation & $\begin{array}{l}\text { More, was contact person for } \\
\text { Project P1 but is sitting with the } \\
\text { customer at Project P3. Much } \\
\text { easier to sit closer to those that } \\
\text { know. (devs). Feels like more } \\
\text { influence and people listen } \\
\text { more. }\end{array}$ & $\begin{array}{l}\text { Much more, Project P4 was } \\
\text { inhouse. Fun, learning from } \\
\text { people that know the system. } \\
\text { Has to be a little careful not to } \\
\text { step on someones toes. If ask } \\
\text { for help everyone helps gladly. } \\
\text { "Being at customer adds } \\
\text { valuable experience" }\end{array}$ & no project relocation \\
\hline
\end{tabular}




\begin{tabular}{|c|c|c|c|c|c|c|}
\hline Q31 & $\begin{array}{l}\text { (Statement) I had } \\
\text { enough time for } \\
\text { preparation before } \\
\text { relocation occurred }\end{array}$ & 5 & no project relocation & 1 & $\begin{array}{l}\text { 2. Too little time, only few days } \\
\text { with other consultant at } \\
\text { customer location. Problem } \\
\text { with walking beside that } \\
\text { customer wants "output" } \\
\text { immediately. "Customer dont } \\
\text { want consultants to use time } \\
\text { for studying the customers } \\
\text { thick files." }\end{array}$ & no project relocation \\
\hline Q32 & $\begin{array}{l}\text { Were there any } \\
\text { experiences from the } \\
\text { previous project that you } \\
\text { had use for in the new? }\end{array}$ & $\begin{array}{l}\text { Test thinking. The physical } \\
\text { devices. Communication }\end{array}$ & no project relocation & & $\begin{array}{c}\text { Creation of test cases. Good } \\
\text { to learn that in inhouse-project } \\
\text { (Project P4). That it isnt design } \\
\text { that should be tested but } \\
\text { requirements. }\end{array}$ & no project relocation \\
\hline Q33 & $\begin{array}{l}\text { Which of the projects felt } \\
\text { the most motivating and } \\
\text { in what way? }\end{array}$ & Hard to say, Auto perhaps & no project relocation & & $\begin{array}{l}\text { Project } \mathrm{P} 3 \text {, especially newest } \\
\text { release along with larger } \\
\text { responsibilities and for more } \\
\text { parts of system. }\end{array}$ & no project relocation \\
\hline Q34 & $\begin{array}{l}\text { Would you be interested } \\
\text { in participating in a quick } \\
\text { computer-based } \\
\text { exercise that indicates } \\
\text { what learning style you } \\
\text { prefer and what } \\
\text { personality you have? }\end{array}$ & Yes & Yes & Yes & Yes & Yes \\
\hline & & & & & & \\
\hline
\end{tabular}




\begin{tabular}{|l|l|l|l|l|}
\hline & & $\begin{array}{l}\text { *C6 started the LazyDog, there } \\
\text { was never time for creating more } \\
\text { advanced documentation. Also } \\
\text { even if test cases dont change, } \\
\text { the tools do. Somene needs to } \\
\text { keep lazydog updated. Project } \\
\text { P1; "unnatural testing", more fun } \\
\text { to lok for errors. Fun challenge } \\
\text { to find errors nobody else have } \\
\text { thought of. }\end{array}$ \\
\hline
\end{tabular}




\section{Appendix D - Improvement suggestions}




\section{D.1 IMPROVEMENT SUGGESTIONS}

As can be seen by information gathered from TestCenter in this study, there is room to introduce a structured process that describes consultant project relocations. The suggestions posed in this study focus on a documentation approach that can be used as a start point for establishing such a process.

Typically one of three relevant relocation situations can be encountered when a TestCenter consultant is assigned to a new test project;

- Project initialization - The consultant is the first representative from TestCenter at place

- Consultant integration - TestCenter consultant(s) are already in place and are not scheduled for other projects in a near future

- Project hand-over - A TestCenter consultant already in place will be exchanged for a new one within a specified time.

These pose different requirements in order to have efficient consultant relocations. In addition there is another aspect of consultant relocations, namely that the consultant being relocated leaves another project behind. If the consultant possess valuable knowledge from that project it needs to be extracted before the relocation. If it is not, knowledge is removed from the old project. Experience showed that this has created situations where the consultant needs to answer questions about the old project at the same time as learning the new project. This will obviously cause interference in the process of learning the new project.

TestCenter relocations have so far depended heavily on learning by asking others. In some cases, like in LicenseTesting, much experience exists already in the TestCenter team and can be used for learning purposes by appointing mentors to new consultants. In other cases, learning has consisted of asking developers or external test engineers directly. Test consultants themselves often consider this a good way of learning new projects, and research have also confirmed that especially mentorship strengthens social acceptance, motivation and several other important factors [11]. It is however questionable if unstructured knowledge acquisition by asking for example a programmer close at hand falls within the benefits of mentorship. A potential drawback with "Learning by direct communication" alone can likely be associated with high overhead costs in certain situations. From the study we have learned that such situations exist in the TestCenter environment, they are;

- If the knowledge recipient is not sure of whom to ask and is forced to ask several persons before he can get the answer.

- If more than one consultant learns the same project this way, the same information needs to be repeated over and over again.

This does not only consume massive amounts of time from the people asked, thus being an expensive process economically. It can also cause irritation and in worst case a tension in the relationship with the customer. While direct communication is indeed valuable both out of social aspects and in most cases also is necessary for learning project specifics, there are potential gains in supplementing this type of learning with a documentation-based one.

\section{D.1.1 Documentation introduction}

The basic approach suggested by the author is for TestCenter to introduce a specific project documentation that reduces the drawbacks of learning by direct and repetitive communication alone. Motivations for such a documentation culture include; 
- As many as half of the project learning challenges identified can likely be essentially reduced at low cost with a concentrated and straightforward documentation.

- Documentation can be reused in at least two ways; both by several consultants using the same documentation inside one project, and that the general documentation template can be reused in numerous projects. Thus the gain increases with both the number of consultant relocations inside a project, as well as with the number of projects introduced to TestCenter. This implies that it should work well with the TestCenter Model.

- Having the same, familiar knowledge repository for all projects will help test consultants locate important information faster with each project relocation made.

- A documentation solution would give support to both consultant integration and consultant handover situations. This means that in handover situations the consultant in place can potentially be exchanged earlier by decreasing walk-aside periods.

- Documentation also offers a mean to reduce the effect of removing knowledge from test projects, thus allowing the relocating consultants to focus on the new project.

The basic idea is that one document is associated with each project, and that consultants have the main (but not full) responsibility of keeping it updated. This is done in order to offer support for faster project preparation and learning to their fellow consultants when they are relocated to this project.

The nature of consultancy work creates obvious limitations to the size of such documentation. It simply does not allow for consultants to spend half their days writing on documentation. Main considerations for the documentation design were therefor to keep it both short, concentrated and easily manageable.

An important motivation for why such a solution should work is the positive response that the so called LazyDog in LicenseTesting has received from all consultants involved. Even though it has a narrower context, the LazyDog is updated in a similar way of using shared responsibility. Since TestCenter consultants are already using this type of documentation it will hopefully contribute to high acceptance of HotDog introduction as well.

\section{D.1.2 Hosting platform}

While details such as contents and work process around the documentation solution will be discussed in later sections, it is also necessary to choose hosting platform for the documentation suggested. Two main technical approaches can be discussed. One is to host the documentation as an editable file on a shared network drive, with possible extension of a version controlling system such as CVS (http://cvs.nongnu.org). The other approach is to host the documentation as a web page which can be accessed over the internet. There are advantages and disadvantages for each of these solutions. There is for instance a security aspect that needs to be considered. TestCenter has today an intranet site which is accessible through VPN (Virtual Private Network) which could support both approaches with encryption for information security purpose. 
Table D. 1. Hosting platform evaluation

\begin{tabular}{|c|c|c|}
\hline Issue & Shared file on network drive & Web page \\
\hline Security & $\begin{array}{l}\text { - Satisfactory as long as file is not } \\
\text { made accessible outside of } \\
\text { TestCenter. There is however in } \\
\text { many cases need to access it } \\
\text { externally, for example if testing } \\
\text { is done at customer site. Access } \\
\text { at customer site could be made } \\
\text { through VPN connection. } \\
\text { - Limited support of access control } \\
\text { to different parts of } \\
\text { documentation }\end{array}$ & $\begin{array}{l}\text { If web page placed on } \\
\text { intranet VPN connection } \\
\text { will offer satisfactory } \\
\text { security. Alternatively a web } \\
\text { page could be made globally } \\
\text { accessible through the } \\
\text { internet, still encrypted with } \\
\text { technologies like SSL. } \\
\text { - Good support of } \\
\text { access control to } \\
\text { different parts of } \\
\text { documentation }\end{array}$ \\
\hline Availability & $\begin{array}{l}\text { High availability at TestCenter, low } \\
\text { availability at customer site. Will either } \\
\text { need VPN connection with drive } \\
\text { mapping towards TestCenter or that } \\
\text { consultant brings the file to customer site. } \\
\text { The latter approach means simultaneous } \\
\text { usage is impossible, risk of data loss and } \\
\text { data inconsistency. Also questionable if } \\
\text { text editor built-in data consistency } \\
\text { controller will be sufficient for } \\
\text { simultaneous access. }\end{array}$ & $\begin{array}{l}\text { - High availability at } \\
\text { TestCenter. If } \\
\text { presented as web } \\
\text { page accessible over } \\
\text { the internet with } \\
\text { SSL and login high } \\
\text { availability also at } \\
\text { customer site. If } \\
\text { accessed through } \\
\text { intranet, low } \\
\text { availability at } \\
\text { customer site. } \\
\text { Technologies such } \\
\text { as RSS feeds could } \\
\text { be introduced with } \\
\text { little effort to } \\
\text { enhance availability, } \\
\text { thus consultants can } \\
\text { receive HotDog } \\
\text { updates even } \\
\text { without visiting the } \\
\text { web page. }\end{array}$ \\
\hline Modifiability & Very high (possibly too high) & $\begin{array}{l}\text { Medium or high depending } \\
\text { on web publication format }\end{array}$ \\
\hline $\begin{array}{l}\text { Post-project } \\
\text { data } \\
\text { management }\end{array}$ & $\begin{array}{l}\text { Low support. Manual data gathering } \\
\text { needed }\end{array}$ & $\begin{array}{l}\text { High support assuming data } \\
\text { is saved in modern database. }\end{array}$ \\
\hline Implementation & Very fast & $\begin{array}{l}\text { From slow to medium-fast } \\
\text { depending on web } \\
\text { technologies used. }\end{array}$ \\
\hline
\end{tabular}

By comparing the approaches it is evident that the intended documentation should be hosted as a web page. The requirement to access the documentation at customer site calls for either the installation of a VPN client or encrypted internet web pages. Installation of VPN client is reasonably fast if a fixed set of computers are dedicated to TestCenter use. It is however still uncertain whether customers will approve the required modifications to their PC installations or not. The recommendation is 
therefore to host the documentation as a web page on the internet, using appropriate encryption, secure login and a database solution.

Depending on the type of web system used, different solutions can offer different degrees of modifiability for consultants. Since a documentation of this kind must be allowed to evolve on its own, high modifiability is essential at least initially. Because of this reason and that documentation evolution should start as soon as possible, a text document has been prepared that can initially be placed on a shared network drive.

A number of headlines to use in the documentation have been suggested on the next page and they relate directly to the project learning challenges experienced by

TestCenter consultants. Naturally it is not possible to decide exactly what information categories give sufficient coverage or in what way information should be written. This depends on too many unknown factors at current date. Instead the documentation template should be seen as a helping hand that offers TestCenter consultants support for evolving a documentation that suits them optimally. It contains general information categories that should be feasible for most test projects in TestCenter.

Preferably the attached documentation template should be evaluated, adjusted and extended by TestCenter during a test period. After having established an effective documentation structure the documentation solution should however be converted into a web page. A version hosted on the internet, or even intranet, could in the future offer large support to consultants that are working at customer sites. 


\section{D.1.3 Documentation contents}

In Figure D. 1 the proposed documentation structure is presented and is later discussed.

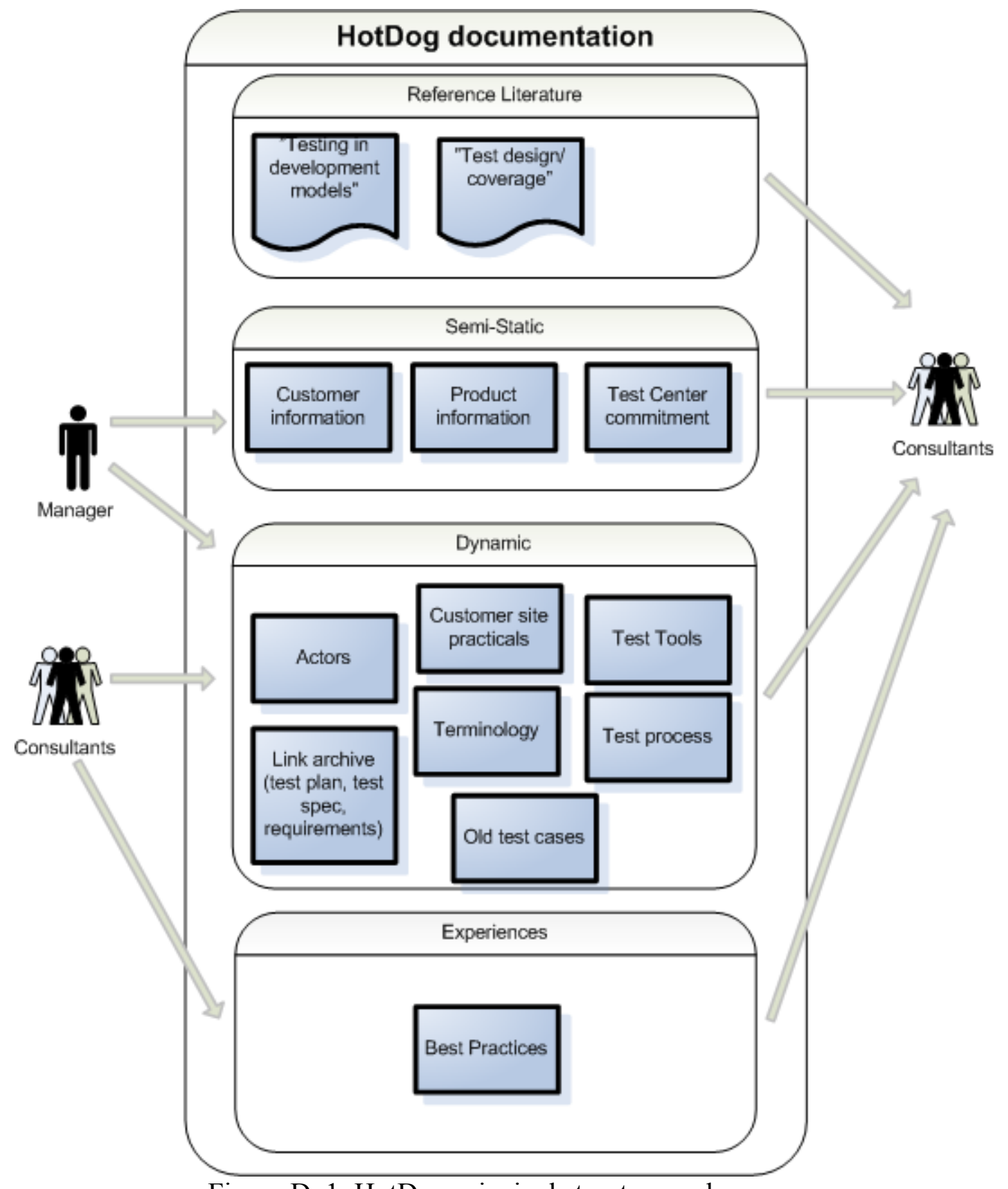

Figure D. 1. HotDog principal structure and process

The name HotDog has been used for association with the consultant administered documentation already in use in Project P1 (LicenseTesting), the LazyDog. The HotDog documentation could in some ways be viewed as a natural extension of the LazyDog. The information categories are spread over three sections depending on information dynamics; 


\section{D.1.3.1 Reference literature}

This section is preloaded with some reference literature that is relevant to software testing and TestCenter in particular. Besides of test design and test coverage articles it also includes an overview of software development models such as Scrum and Extreme Programming (XP). This is because there are large differences in test aspects within traditional waterfall development as compared to agile. This section should be extended whenever TestCenter finds additional literature of interest to either testing in general or to specific projects. The basic idea of the section is that the literature is never edited internally.

\section{D.1.3.2 Semi-static}

Contents within the semi-static section are seldom changed. It constitutes high-level administrational contents of the specific project. Customer information can be a description of the customer, such as its business area, goals and basic organization. Product

information is a short presentation of the product that should be tested and the environment in which it operates. TestCenter commitment describes the commitment that TestCenter has in this project, i.e. type of responsibilities etc. This section should only be administered by a manager, and eventual changes be requested by consultants.

\section{D.1.3.3 Dynamic}

This is the main section of the documentation. It contains the major part of the information that can be used for learning and everyday usage by consultants. Consultants have full access to it, and are encouraged to keep this section updated. Managers can eventually enter some initial information such as main contact person etc. Actors contains contact information and description of people involved in the project which are relevant to the test purpose.

Customer site practicals is used if consultants are working at a customer site. It can contain information about everything from office working hours, to fire escape plans. Note that document encryption and permission might be required in order to store more sensitive information here such as alarm codes and login credentials. Terminology is a straightforward two-column dictionary that can help new consultants quickly learn the "native language" of project members. The Link archive is an essential part of the documentation. Experiences have shown that the gathering of links to various project documents is valuable. Because documentation availability and structure differ very much from project to project, especially in a consultancy context, a central gathering of documents is believed to be of great help to consultants. Modern documentation formats support various link formats, such as internet URL addresses and network file resources which is a good starting point. Examples of contents in the link archive are important documentation such as Test specifications, Requirements specifications and Test plans. Old test cases can be used for learning purposes if they are copied into this category. Depending on the format it might be appropriate to use the Link archive instead. Test tools should contain information about what tools are being used that are relevant to testing, for example bug reporting system or requirements tools. An idea is to provide screenshot examples. Test process describes when and how testing is conducted, what documents are used etc.

\section{D.1.3.4 Best practices}

For years Siemens has been working actively with knowledge management [20]. One of the reasons for this is that many of their software development projects are conducted in multisite global environments; hence there is a large need for knowledge coding and distribution. The geographical aspect is not of significant relevancy to TestCenter because the projects conducted there are mainly in their close environments. There is nonetheless a need to codify and distribute knowledge about a project, from consultant to consultant in order to increase both test efficiency and project learning. Siemens has successfully been using what they call Best Practice Templates (Bass, $\mathrm{M}$ et. al) to gather best practices in form of practice patterns 
that can be easily shared. A best practice template is structurally nothing but a template that contains a number of descriptions and motivations that describes a procedure that has had a positive effect to a process or problem that has occurred. The structured template does however offer not only a way to share experiences and put them in context, but also a way to classify and generalize experiences to a broader purpose such as cross-project learning in the case of TestCenter, should the future prove this valuable. By using a subset of the factors from Siemens Best Practice Templates the basic idea is to let consultants in TestCenter write down any best practices discovered in a structured manner, in order to make them reusable by other TestCenter consultants that joins the same project. While the consultants at LicenseTesting have already integrated best practices in the LazyDog documentation before, this section could likely be embraced as a natural extension to the documentation. It is especially believed that this section can prove extra valuable in case the consultant is the only one from TestCenter in a project, thus knowledge can be shared to the document as a reusable alternative to communicating it only verbally to a colleague.

\section{D.1.4 Process of introducing and maintaining HotDog documentation}

An essential prerequisite for establishing an effective documentation is to have clear routines of how to work with it. It is vital to the success of the concept that such routines are settled, communicated and embraced unanimously. This means that management will have a large responsibility in communicating the importance of having a central way of documenting projects. The managerial benefits can be large in means of achieving a more effective learning process and thus supporting the TestCenter Model by reducing consultants' project introduction/learning periods. To the consultants it means that energy that traditionally was used on trying to find the right person to ask, or how to locate different parts of documentation, can now be used on learning the actual product to test and the test process itself. In addition an existing documentation will enable consultants to prepare before relocation by learning the essentials of a project before he sets foot in the customer site. This will likely decrease the period that consultants need to walk-aside each other and also gives a good impression to the customer by being familiar with their concepts from day one. The price for this is that everyone needs to help keeping the documentation updated, giving that we need to spend a little time in order to gain large time. It should be noted that consultants in so called LicenseTesting have already managed well to establish a similar documentation, which indicates that the consultants already have an acceptance and (positive) experience of managing documentation. Below is a suggestion for a HotDog documentation process with examples for each of the three relocation situations. Like with the contents of documentation the process needs to be adjusted according to practical circumstances.

\section{D.1.4.1 Project Initialization}

\section{A manager gathers required initial information to fit into the Semi-static} section of the documentation. Additional details about contact persons is also entered.This is done only one time per project and will therefor take relatively small time in account. This should be finished as early as possible before the first consultant joins the project in order to enable the consultant to use the information before relocation.

2. Continous documentation updates by consultants. The first TestCenter consultant or consultants in the project will naturally spend more time on transferring knowledge into the HotDog than consultants that arrive later. In order to not interfer with daily work, it is recommended that either documentation updates are made outside of customer work hours, or that TestCenter from the beginning reserves one consultant hour per week for administrational purposes. An issue of who will then 
take this cost might have to be discussed by management. One alternative is that TestCenter stands for this weekly hour since it does not produce a direct gain to the customer. Another is that the concept can be sold to the customer from the very beginning, by using arguments like increased quality by using TestCenter standard documentation efforts.

\section{D.1.4.2 Consultant integration}

1. HotDog is communicated to the new consultant in advance. Management should ensure that the consultant reserves at least one work hour to study the HotDog before relocation occurs.

2. HotDog is applied as a complement to traditional learning processes such as walk-aside.

3. HotDog is evaluated by the new consultant and feedback is given. HotDog is updated together with other TestCenter consultants in the project, should information be missing or incorrect. This is an event that preferrably could be done after a couple of weeks. In a consultant integration situation several TestCenter test consultants are working simultaneously. Changes to HotDog might then need to be discussed with the others before implementation. Depending on the number of active TestCenter consultants in a project it might be convenient if one consultant has the main responsibility for HotDog updates for that project.

4. Continous documentation updates by consultants. Similar to the description in Project Initialization, but with less time required.

\section{D.1.4.3 Project hand-over}

1. The consultant that is leaving the project makes a full walk-through of the HotDog and apply relevant updates in reasonable time before his or her project participation ends, but before the new consultant is introduced. This requires that the consultant at location receives information about the project hand-over situation at an early stage.

2. HotDog is communicated to the new consultant in advance. Management should ensure that the consultant reserves at least one work hour to study the HotDog before relocation occurs.

3. HotDog is applied as a complement to traditional learning processes such as walk-aside.

4. Continous documentation updates by consultant. Similar to the description in Project Initialization, but with less time required.

\section{D.1.5 Limitations of proposed solution}

The HotDog documentation is feasible in most, but not all situations. In a resource consulting situation where it is obvious that TestCenter has no opportunity of expanding or even remaining with the project for a longer period, the proposed documentation approach will likely not be cost effective. This calls for management to try the decision of whether a HotDog is feasible on a case-by-case basis. 


\section{D.1.6 Security considerations of knowledge encoding}

While HotDog introduces the possibility of encoding knowledge of all types, it can be discussed if all types of knowledge are feasible to codify. There are two main concerns regarding information handling that needs to be addressed.

- Uncontrolled outward information distribution

When knowledge is encoded it becomes very easily distributable. The benefits are naturally that project learning can be improved, but there is one main disadvantage. The highly distributable form of HotDog however also means we need to take countermeasures to prevent HotDog from spreading sensitive customer information uncontrolled outside of the customer organization. The codification of test staff experiences involves information only intended for the customer organization. Even if a TestCenter consultant has justifiable access to this information, it is an important aspect that care is taken not to distribute the HotDog to other parties, including external parties as well as unauthorized Cybercom instances. The suggestion is therefore that a security clearance level is associated with each HotDog and that file access is strictly granted accordingly. Consultants must also be informed that the HotDog may not be distributed to other actors.

- Uncontrolled inward information distribution

It might not be sufficient to prevent the outside world from gaining access to HotDog documents. The cross-cultural nature of consultant work means documentation can potentially contain information, opinions, comparisons and experiences that are not meant for customer access but strictly for TestCenter access. It is not possible to guarantee that encrypted information transfers between customer site and TestCenter alone will prevent customer personnel from reading the HotDog. A HotDog document accessed by a TestCenter consultant on any customer-controlled computer can likely also be viewed by the customer. There are two basic approaches to handling this issue;

- Knowledge that can be asumed to affect relationships between TestCenter and their customers should not be codified and entered into a HotDog. These issues should instead be communicated using standard communication procedures and their channels. A potential problem is for the consultant to know what information needs to remain the asset of TestCenter. Guidelines need to be created by TestCenter to help determine the degrees of confidentiality for different information types.

- Only using Cybercom computers at customer sites. This is unlikely to be an acceptable solution to neither Cybercom nor the customer, due to both practical reasons and the fact that some organizations do not allow foreign computers to be installed in their network unless installed with a customer-approved standard set of software. Additionally it does not eliminate security threats completely, i.e. computers still need screen locks so that accidental retrieval by office by-passers is prevented.

In the initial form of HotDog, the plain document file, extra careful attention must be paid so that the HotDog files are not accidently distributed, i.e. physical displacement of data media. 


\section{D.1.7 Embedded documents}

Appendix D was negligibly modified and sent to the TestCenter project manager as improvement suggestions report. In that report section D.1.7 contained two embedded documents; the HotDog template and a fictive example of a HotDog document.

Since these documents were created in a format chosen with concern of the software suite of TestCenter, screendumps were taken and are presented in Figure D. 2. HotDog Page 1 screen dump and Figure D. 4. HotDog Best Practices document screen dump. Before screen dumps were made, the original text was translated from Swedish to English. 


\section{HotDog}

\section{Project name}

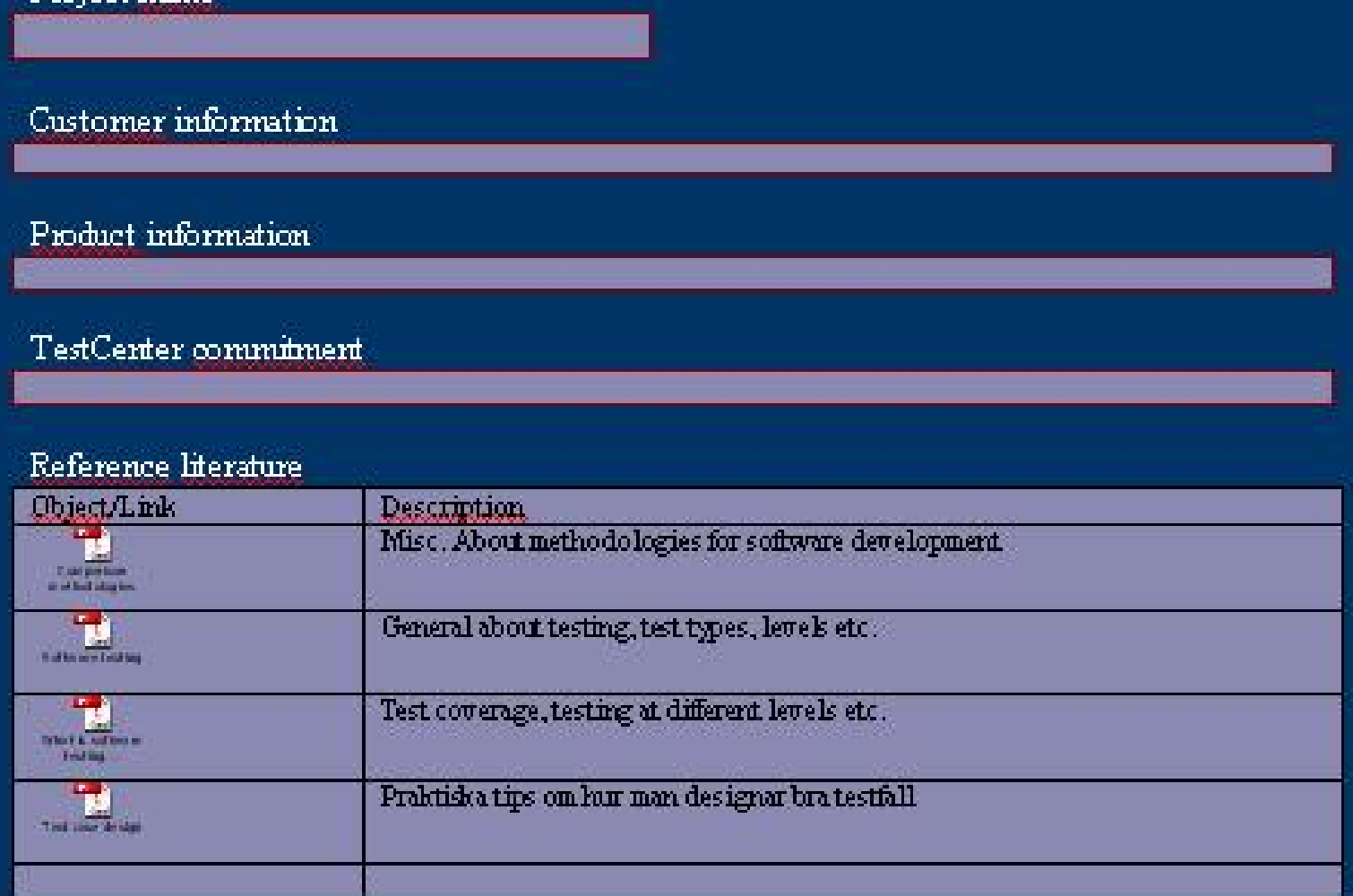

\section{Contacts}

\begin{tabular}{|c|c|c|c|}
\hline Hame. & Mail & Phome & Role / Compitence \\
\hline & & & \\
\hline & & & \\
\hline & & & \\
\hline & & & \\
\hline
\end{tabular}

\section{Practicals}

\begin{tabular}{|l|}
\hline \\
\hline
\end{tabular}

\section{Link archive}

\begin{tabular}{|l|l|l|}
\hline Adresse & Descrintion & Comment. \\
\hline & & \\
\hline & & \\
\hline & & \\
\hline & & \\
\hline & & \\
\hline
\end{tabular}

Figure D. 2. HotDog Page 1 screen dump 
Teminology

\begin{tabular}{|l|l|}
\hline Tem & Descrintion. \\
\hline & \\
\hline & \\
\hline & \\
\hline
\end{tabular}

Test process

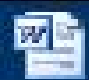

Test tools
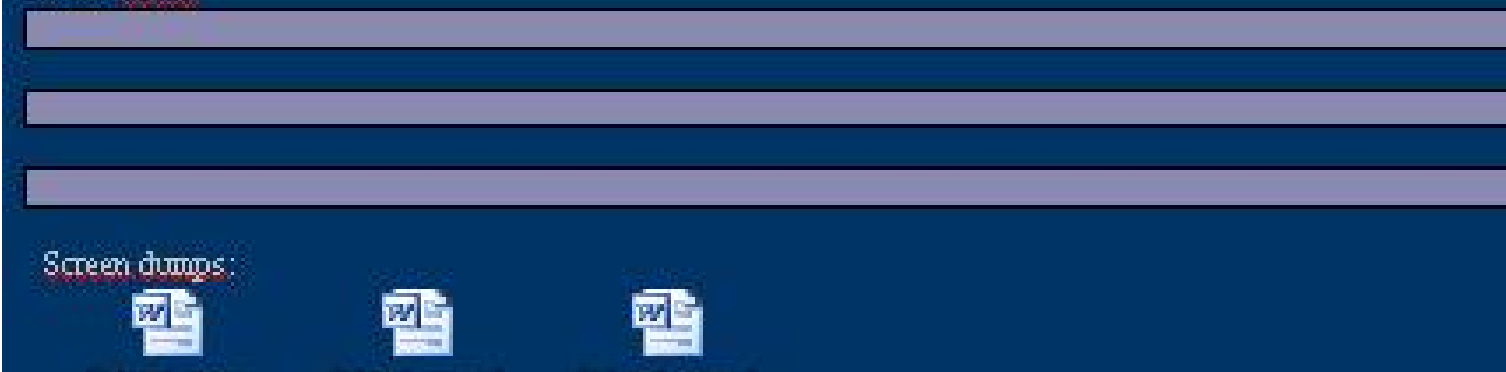

Test case examples

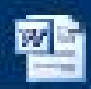

Best Practices

wit

Figure D. 3. HotDog Page 2 screen dump 


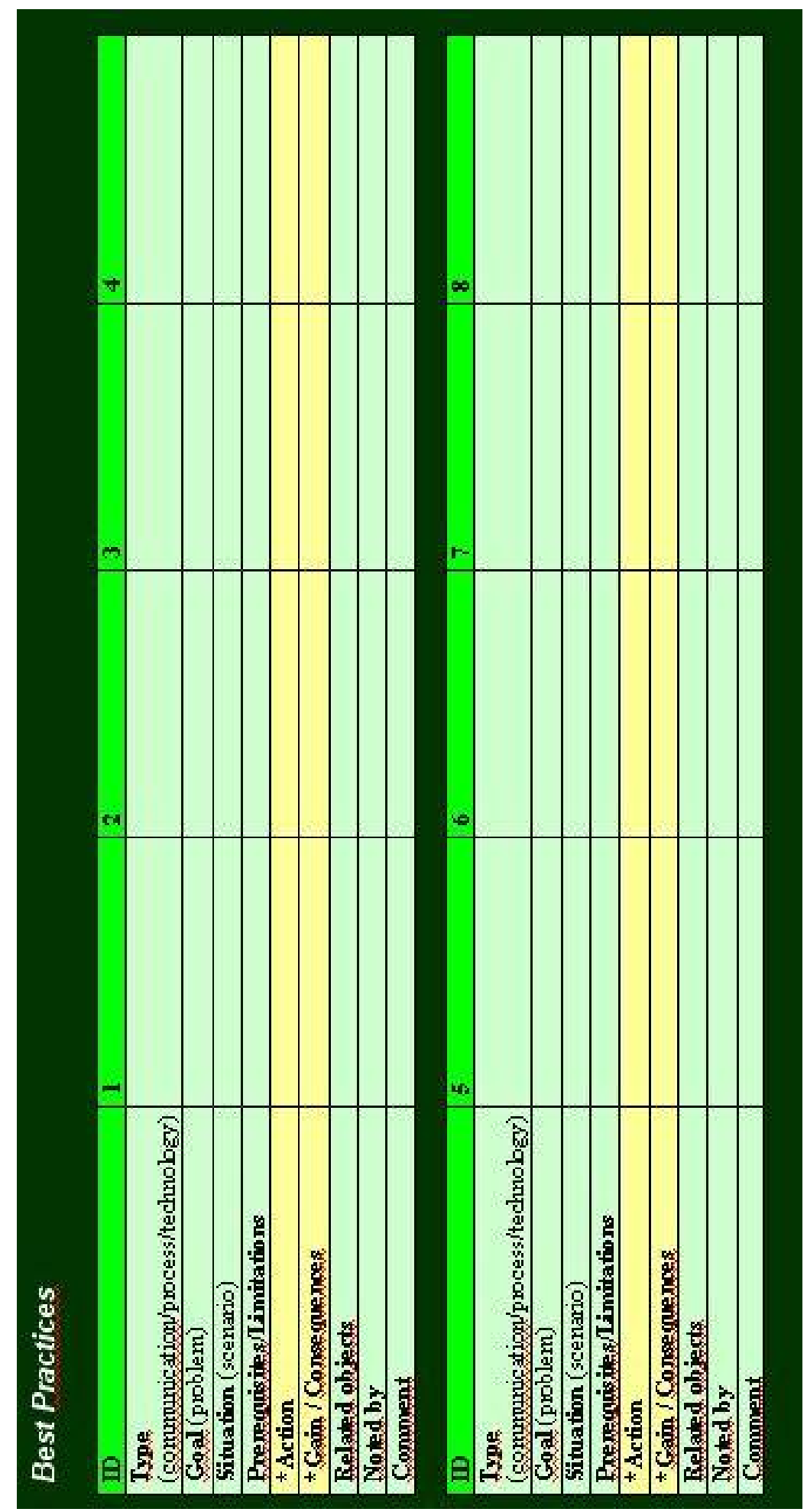

Figure D. 4. HotDog Best Practices document screen dump 


\section{Appendix E - Questions and answers for static validation}




\section{E.1. QUESTIONS AND ANSWERS FROM STATIC VALIDATION INTERVIEW}

Table E. 1. Interview results from static validation

\begin{tabular}{|c|c|c|c|}
\hline Category & $\begin{array}{l}\text { Question } \\
\text { ID }\end{array}$ & Question & $\begin{array}{l}\text { Answer from project } \\
\text { manager }\end{array}$ \\
\hline \multirow[t]{5}{*}{ General concept } & 1 & $\begin{array}{l}\text { Do you think the proposed documentation } \\
\text { solution could decrease the learning time } \\
\text { for test consultants in new projects? }\end{array}$ & $\begin{array}{l}\text { Absolutely. There should } \\
\text { be one for all our test } \\
\text { projects. Good that } \\
\text { suggestions were tangible. } \\
\text { Good that different types of } \\
\text { project staff relocations } \\
\text { were identified. The } \\
\text { gathering of information } \\
\text { will help decrease learning } \\
\text { time. }\end{array}$ \\
\hline & 2 & $\begin{array}{l}\text { Could it become useful to the consultants } \\
\text { after the introduction time in the projects? }\end{array}$ & $\begin{array}{l}\text { Difficult to say. Perhaps } \\
\text { not after half a year } \\
\text { experience from the } \\
\text { project. Definitely for } \\
\text { project newcomers. }\end{array}$ \\
\hline & 3 & $\begin{array}{l}\text { Could it contribute to decreasing the } \\
\text { amount of knowledge that disappears from } \\
\text { projects when consultants leave them? }\end{array}$ & $\begin{array}{l}\text { Yes, it is easy to forget to } \\
\text { pass on knowledge about } \\
\text { details, links to documents } \\
\text { etc. Especially good for } \\
\text { projects where customer } \\
\text { company size is small } \\
\text { because there are often few } \\
\text { other test consultants that } \\
\text { can aid there. }\end{array}$ \\
\hline & 4 & $\begin{array}{l}\text { Would an implementation of the } \\
\text { suggestions have an effect on staff } \\
\text { mobility? }\end{array}$ & $\begin{array}{l}\text { The company would } \\
\text { probably notice relocations } \\
\text { as more smooth. The } \\
\text { consultant would feel more } \\
\text { mobile because he or she } \\
\text { can prepare before } \\
\text { relocation and the HotDog } \\
\text { can feel more confident. }\end{array}$ \\
\hline & 5 & $\begin{array}{l}\text { Did the reading of improvement } \\
\text { suggestions give you any ideas of your own } \\
\text { on how they could be adjusted or } \\
\text { enhanced? }\end{array}$ & $\begin{array}{l}\text { It is important that } \\
\text { everyone contributes. We } \\
\text { need to develop a detailed } \\
\text { process of how the HotDog } \\
\text { should be updated. Also } \\
\text { create rules for what details } \\
\text { are appropriate to write. A } \\
\text { evaluation in sharp } \\
\text { environment is interesting } \\
\text { to provide initial feedback } \\
\text { for closer process } \\
\text { definition. }\end{array}$ \\
\hline $\begin{array}{l}\text { Experience } \\
\text { patterns }\end{array}$ & 6 & $\begin{array}{l}\text { Can you, out of a consultant's perspective, } \\
\text { find any use of consultants saving their }\end{array}$ & $\begin{array}{l}\text { Yes. Tips and Tricks has } \\
\text { worked well in i.e. the }\end{array}$ \\
\hline
\end{tabular}




\begin{tabular}{|c|c|c|c|}
\hline & & experiences during the projects? & $\begin{array}{l}\text { LazyDog in order to know } \\
\text { what document should be } \\
\text { used in what situation. A } \\
\text { risk is that written } \\
\text { experiences get widespread } \\
\text { and difficult to gather. } \\
\text { More subsections could be } \\
\text { necessary. }\end{array}$ \\
\hline & 7 & $\begin{array}{l}\text { Can you see any benefits of written "Best } \\
\text { practices" from the company's perspective? }\end{array}$ & $\begin{array}{l}\text { Absolutely. One example } \\
\text { can be to gather experience } \\
\text { from different test tools. } \\
\text { TestCenter is currently } \\
\text { trying to gather experiences } \\
\text { from usage of different } \\
\text { tools in order to } \\
\text { recommend tool packages } \\
\text { to customers. }\end{array}$ \\
\hline & 8 & $\begin{array}{l}\text { Do you think it would be difficult to get the } \\
\text { consultants to write down their experience } \\
\text { in this way? }\end{array}$ & $\begin{array}{l}\text { Not really. A difficult thing } \\
\text { is however that people take } \\
\text { things for granted and does } \\
\text { not always realize what } \\
\text { knowledge needs to be } \\
\text { shared. }\end{array}$ \\
\hline & 9 & $\begin{array}{l}\text { Would it be possible to change or extend } \\
\text { the factors that I suggested in "Best } \\
\text { practices" to better suite the test } \\
\text { consultancy domain? }\end{array}$ & $\begin{array}{l}\text { The proposed categories } \\
\text { seem to be a good basis to } \\
\text { start with. Too early to see } \\
\text { suitable adjustments at this } \\
\text { stage, needs to be } \\
\text { practically evaluated first. }\end{array}$ \\
\hline Implementation & 10 & $\begin{array}{l}\text { If you advertised this or a similar solution, } \\
\text { do you think consultants would embrace it } \\
\text { as a natural part of their work? }\end{array}$ & $\begin{array}{l}\text { Yes, confident that they } \\
\text { would see the benefits of it. } \\
\text { However it will be } \\
\text { important to motivate them } \\
\text { to take time off for it. }\end{array}$ \\
\hline & 11 & $\begin{array}{l}\text { On average } 15 \text { minutes per project and } \\
\text { week, does that seem like a resonable time } \\
\text { estimation? }\end{array}$ & $\begin{array}{l}\text { Not sure if an average } \\
\text { weekly measure is } \\
\text { appropriate. Updates will } \\
\text { likely be made as larger } \\
\text { activities in the start and } \\
\text { end of projects. }\end{array}$ \\
\hline & 12 & $\begin{array}{l}\text { How large would the time usage for } \\
\text { introduction and maintenance of the } \\
\text { documentation become in relation to the } \\
\text { time that could be saved? }\end{array}$ & $\begin{array}{l}\text { There would be large time } \\
\text { savings in most cases. } \\
\text { Benefit size depends on } \\
\text { project size and the number } \\
\text { of relocations. Probably not } \\
\text { beneficial in short projects } \\
\text { (few relocations). }\end{array}$ \\
\hline Obstacles & 13 & $\begin{array}{l}\text { What disadvantages and difficulties would } \\
\text { the introduction and usage of this } \\
\text { documentation introduce? }\end{array}$ & $\begin{array}{l}\text { 1) Cost for updates needs to } \\
\text { be considered. Should } \\
\text { TestCenter or customer pay } \\
\text { for that time? Some } \\
\text { customers likely think it is } \\
\text { ok to pay for. 2) Everyone } \\
\text { does not enjoy writing }\end{array}$ \\
\hline
\end{tabular}




\begin{tabular}{|l|l|l|l|}
\hline & & documentation. \\
\hline 14 & $\begin{array}{l}\text { Which bowl do you think is the heavier } \\
\text { one; pros or cons? }\end{array}$ & $\begin{array}{l}\text { Definitely the pros. } \\
\text { However the real effect of } \\
\text { pros and cons will be more } \\
\text { obvious after a trial. }\end{array}$ \\
\hline
\end{tabular}




\section{References}

[1] J. Jurison, "Software Project Management: The manager's view", Communications of the Association for Information Systems, vol. 2, art. 17, 1999.

[2] S. R. Rakitin, Software verification and validation for practitioners and managers, London, UK: Boston Mass., 2001.

[3] D. Gelperin and B. Hetzel, "The Growth of Software Testing", Communications of the $A C M$, vol. 31, pp. 687-695, 1988.

[4] I. Sommerville, Software Engineering, Harlow, UK: Pearson Higher Education, 2004.

[5] P. Boxall and M. Steeneveld, "Human resource strategy and competitive advantage: A longitudinal study of engineering consultancies", The Journal of management studies, vol. 36, no. 4, p. 443, 1999.

[6] P. M. Wright and G. C. McMahan, "Theoretical Perspectives for Strategic Human Resource Management”, The Journal of management, vol. 18, no. 2, p. 295, 1992.

[7] J. T. Delaney and M. A. Huselid, "The Impact of Human Resource Management Practices on Perceptions of Organizational Performance", Academy of Management journal, vol. 39, no. 4, p. 949, 1996.

[8] A. Belout and C. Gauvreau, "Factors influencing project success: the impact of human resource management", International journal of project management, vol. 22, no. 1, p. 1, 2004

[9] J. Söderlund and K. Bredin, "HRM in project-intensive firms: changes and challenges", Human resource management, vol. 45, no. 2, p. 249, 2006

[10] N. M. Agrawal and M. Thite, "Human resource issues, challenges and strategies in the Indian software industry", International Journal of Human Resources Development and Management, vol. 3, no. 3, pp. 249-264, 2003

[11] F. O. Bjørnson and T. Dingsøyr Torgeir, "A Study of a Mentoring Program for Knowledge Transfer in a Small Software Consultancy Company" in Product Focused Software Process Improvement, Heidelberg, Germany: Springer Berlin, 2005, pp. 245-256.

[12] M. Weiser and J. Morrison, "Project Memory: Information Management for Project Teams", Journal of Management Information Systems, vol. 14, no. 4, p. 149, 1998.

[13] C. W. Dawson, Projects in Computing and Information Systems - A Student's Guide, Harlow, UK: Pearson Higher Education, 2005

[14] D. A. Kolb, Learning Style Inventory: technical manual, Englewood Cliffs, New York: Prentice-Hall, 1976.

[15] Widgix Software. SurveyGizmo. [Online]. Available: http://www.surveygizmo.com.

[16] R. Feldt, A. Lefteris and M. Samuelsson., "Correlations between Personality and Attitudes in Software Engineering", in submission, 2007 
[17] L. R. Goldberg, "The international personality item pool and the future of publicdomain personality measures", Journal of Research in Personality, vol. 40, no. 1, p. 84, 2006

[18] R. R. McCrae and P.T Costa Jr., "Reinterpreting the Myers-Briggs Type Indicator from the perspective of the five-factor model of personality", Journal of personality, vol. 57, no. 1 , pp. 17-40, 1989

[19] G. Kotonya and I. Sommerville, Requirements Engineering: Processes and Techniques, Chichester, UK: Wiley \& Sons Ltd, 1998

[20] M. Bass, J.D. Herbsleb and C. Lescher, "Collaboration in Global Software Projects at Siemens: An Experience Report", Global Software Engineering, IEEE int. conference on, 2007

[21] W. Trochim. Web center for Social Research Methods. [Online]. Available: http://www.socialresearchmethods.net.

[22] A. Strauss and J. M. Corbin, Basics of Qualitative Research: Techniques and Procedures for Developing Grounded Theory, 2nd ed. Thousand Oaks: SAGE Publications, 1998

[23] L. Bratthall and M. Jørgensen, "Can you Trust a Single Data Source Exploratory Software Engineering Case Study?”, Empirical Software Engineering, vol. 7, no. 1, pp. 9-26, 2002

[24] A. G. Sutcliffe, A. Economou and P. Markis, "Tracing Requirements Errors to Problems in the Requirements Engineering Process", Requirements Engineering, vol. 4, no. 3, pp. 134151,1999

[25] J. J. Koob, J. Funk, “Kolb's Learning Style Inventory: Issues of Reliability and Validity", Research on social work practice, vol. 12, no. 2, p.293, 2002

[26] T. Buchanan. Online Implementation of an IPIP Five Factor Personality Inventory. [Online]. Available: http://www2.wmin.ac.uk/ buchant/wwwffi/introduction.html

[27] M. A. Awad, "A Comparison between Agile and Traditional Software Development Methodologies", University of Western Australia, 2005

[28] H. Freeman, "Software Testing", IEEE instrumentation \& measurement magazine, vol. 5 , no. 3, p. 48, 2002

[29] J. A. Whittaker, "What is software testing? And why is it so hard?", IEEE software, vol. 17 , no. 1 , p. 70,2000

[30] T. Yamaura, "How To Design Practical Test Cases", IEEE software, vol. 15, no. 6, p.30, 1998

[31] A. Prencipe, F. Tell, "Inter-project learning: processes and outcomes of knowledge codification in project-based firms", Research Policy, vol. 30, no. 9, p.1373, 2001

[32] B. Ancori, A. Bureth and P.Cohendet, "The Economics of Knowledge: The Debate about Codification and Tacit Knowledge", Industrial and Corporate Change, vol. 9, no. 2, p. 255,2000 
[33] D. Stenmark, "Leveraging Tacit Organizational Knowledge", Journal of management information systems, vol. 17, no. 3, p. 9, 2000

[34] Cybercom Group web site. [Online]. Available: http://www.cybercomgroup.com

[35] P. Abrahamsson, O. Salo, J. Ronkainen and J. Warsta, "Agile software development methods - Review and analysis", Espoo, Finland: VTT publications, 2002

[36] J. K. Eskildsen, "Work motivation and job satisfaction in the Nordic countries", Employee Relations, vol. 26, no. 2, pp. 122-136, 2004

[37] J. E. Sharp, "Teaching teamwork communication with Kolb learning style theory", presented at the 31st annual Frontiers in Education Conference, Reno, NV, 2001 